\title{
THE MIDWESTERN BASINS AND ARCHES REGIONAL AQUIFER SYSTEM IN PARTS OF INDIANA, OHIO, MICHIGAN, AND ILLINOIS - SUMMARY
}

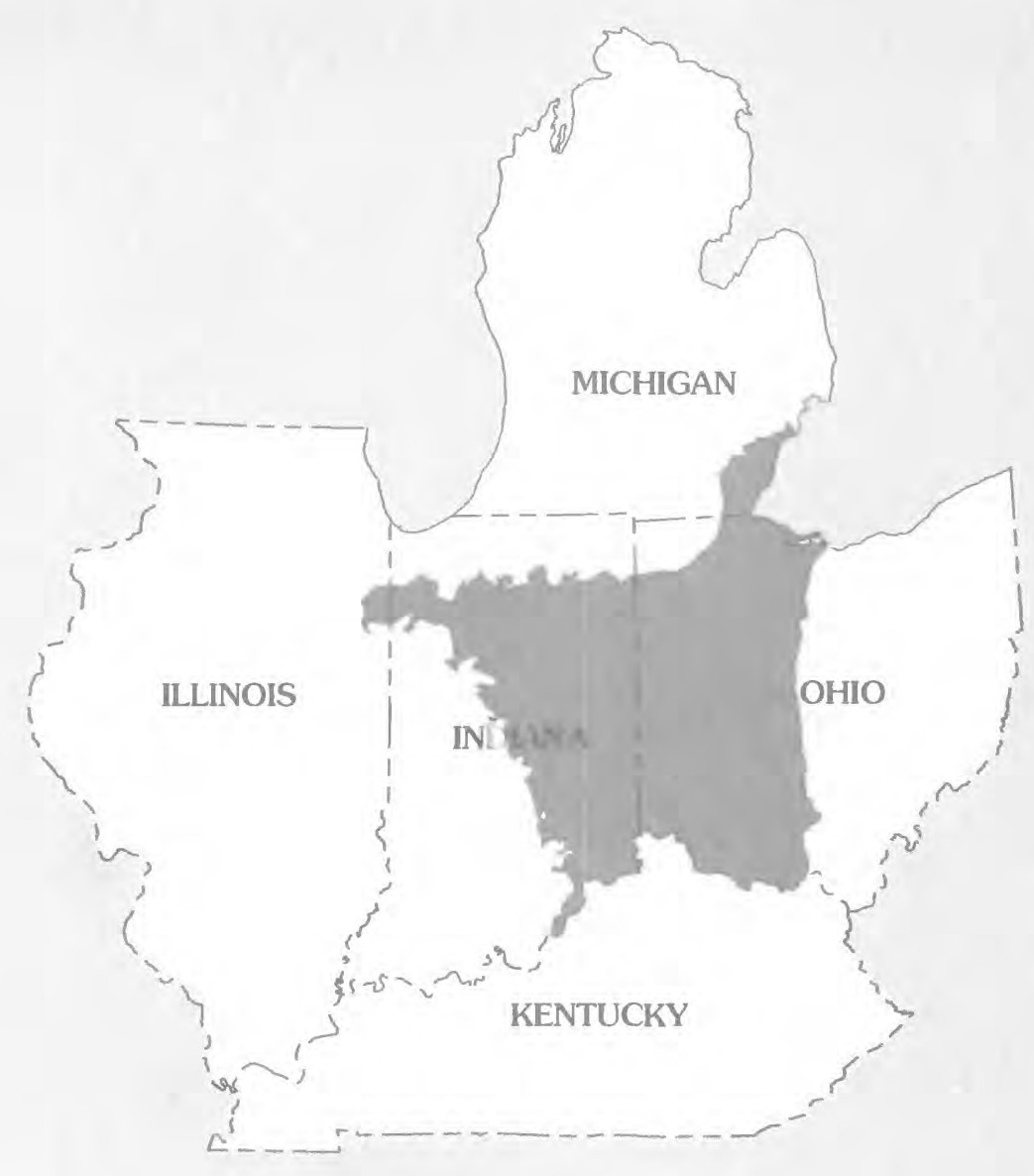




\section{Availability of Publications of the U.S. Geological Survey}

Order U.S. Geological Survey (USGS) publications from the offices listed below. Detailed ordering instructions, along with prices of the last offerings, are given in the current-year issues of the catalog "New Publications of the U.S. Geological Survey."

\section{Books, Maps, and Other Publications}

By Mail

Books, maps, and other publications are available by mail from-

USGS Information Services

Box 25286, Federal Center

Denver, CO 80225

Publications include Professional Papers, Bulletins, WaterSupply Papers, Techniques of Water-Resources Investigations, Circulars, Fact Sheets, publications of general interest, single copies of permanent USGS catalogs, and topographic and thematic maps.

\section{Over the Counter}

Books, maps, and other publications of the U.S. Geological Survey are available over the counter at the following USGS Earth Science Information Centers (ESIC's), all of which are authorized agents of the Superintendent of Documents:

- Anchorage, Alaska-Rm. 101, 4230 University Dr.

- Denver, Colorado-Bldg. 810, Federal Center

- Menlo Park, California-Rm. 3128, Bldg. 3, 345 Middlefield Rd.

- Reston, Virginia-Rm. 1C402, USGS National Center, 12201 Sunrise Valley Dr.

- Salt Lake City, Utah-2222 West, 2300 South (books and maps available for inspection only)

- Spokane, Washington-Rm. 135, U.S. Post Office Building, 904 West Riverside Ave.

- Washington, D.C.-Rm. 2650, Main Interior Bldg., 18 th and C Sts., NW.

Maps only may be purchased over the counter at the following USGS office:

- Rolla, Missouri-1400 Independence Rd.

\section{Electronically}

Some USGS publications, including the catalog "New Publications of the U.S. Geological Survey" are also available electronically on the USGS's World Wide Web home page at http://www.usgs.gov

\section{Preliminary Determination of Epicenters}

Subscriptions to the periodical "Preliminary Determination of Epicenters" can be obtained only from the Superintendent of
Documents. Check or money order must be payable to the Superintendent of Documents. Order by mail from-

Superintendent of Documents

Government Printing Office

Washington, DC 20402

\section{Information Periodicals}

Many Information Periodicals products are available through the systems or formats listed below:

\section{Printed Products}

Printed copies of the Minerals Yearbook and the Mineral Commodity Summaries can be ordered from the Superintendent of Documents, Government Printing Office (address above). Printed copies of Metal Industry Indicators and Mineral Industry Surveys can be ordered from the Center for Disease Control and Prevention, National Institute for Occupational Safety and Health, Pittsburgh Research Center, P.O. Box 18070, Pittsburgh, PA 15236-0070.

\section{Mines FaxBack: Return fax service}

1. Use the touch-tone handset attached to your fax machine's telephone jack. (ISDN [digital] telephones cannot be used with fax machines.)

2. Dial (703) 648-4999.

3. Listen to the menu options and punch in the number of your selection, using the touch-tone telephone.

4. After completing your selection, press the start button on your fax machine.

\section{CD-ROM}

A disc containing chapters of the Minerals Yearbook (199395), the Mineral Commodity Summaries (1995-97), a statistical compendium (1970-90), and other publications is updated three times a year and sold by the Superintendent of Documents, Government Printing Office (address above).

\section{World Wide Web}

Minerals information is available electronically at http://minerals.er.usgs.gov/minerals/

\section{Subscription to the catalog "New Publications of the U.S.} Geological Survey"

Those wishing to be placed on a free subscription list for the catalog "New Publications of the U.S. Geological Survey" should write to-

U.S. Geological Survey

903 National Center

Reston, VA 20192 


\section{The Midwestern Basins and Arches Regional Aquifer System in Parts of Indiana, Ohio, Michigan, and Illinois- Summary}

By E.F. BUGLIOSI

REGIONAL AQUIFER-SYSTEM ANALYSIS-MIDWESTERN BASINS AND ARCHES

U.S. GEOLOGICAL SURVEY PROFESSIONAL PAPER 1423-A 


\title{
U.S. DEPARTMENT OF THE INTERIOR BRUCE BABBITT, Secretary
}

\section{U.S. GEOLOGICAL SURVEY}

\author{
Charles G. Groat, Director
}

Any use of trade, product, or firm names in this publication is for descriptive purposes only and does not imply endorsement by the U.S. Government.

Reston, Virginia 1999

Library of Congress Cataloging in Publication Data

Buliosi, Edward F.

The Midwestern basins and arches regional aquifer system in parts of Indiana, Ohio, Michigan, and Illinois : summary/by E. F. Bugliosi. p. cm. - (U.S. Geological Survey professional paper; 1423-A)

Includes bibliographical references (p. ).

ISBN 0-607-92591-4

1. Aquifers-Middle West. 2. Groundwater flow-Middle West. I. National Regional Aquifer Systems Analysis Program (U.S.) II. Title. III. Series. GB1199.3.M54B84 1999

$551.49^{\prime} 0977-\mathrm{d} 21$

For sale by U.S. Geological Survey, Branch of Information Services, Box 25286, Federal Center, Denver, CO 80225 


\section{FOREWORD}

THE REGIONAL AQUIFER-SYSTEM ANALYSIS PROGRAM

The Regional Aquifer-System Analysis (RASA) Program represents a systematic effort to study a number of the Nation's most important aquifer systems, which, in aggregate, underlie much of the country and which represent an important component of the Nation's total water supply. In general, the boundaries of these studies are identified by the hydrologic extent of each system and, accordingly, transcend the political subdivisions to which investigations have often arbitrarily been limited in the past. The broad objective for each study is to assemble geologic, hydrologic, and geochemical information; to analyze and develop an understanding of the system; and to develop predictive capabilities that will contribute to the effective management of the system. The use of computer simulation is an important element of the RASA studies to develop an understanding of the natural, undisturbed hydrologic system and the changes brought about in it by human activities, and to provide a means of predicting the regional effects of future pumping or other stresses.

The final interpretive results of the RASA Program are presented in a series of U.S. Geological Survey Professional Papers that describe the geology, hydrology, and geochemistry of each regional aquifer system. Each study within the RASA Program is assigned a single Professional Paper number beginning with Professional Paper 1400.

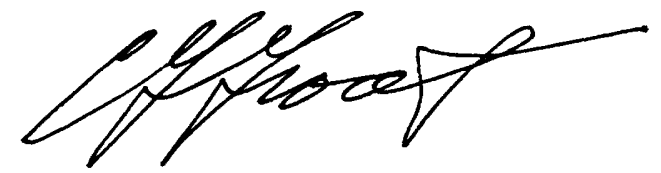

Charles G. Groat Director 


\section{CONTENTS}

\begin{tabular}{|c|c|c|c|}
\hline & Page & & Page \\
\hline orward .. & III & Middle and upper Devonian and Mississippian & \\
\hline 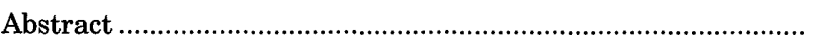 & $\mathrm{A} 1$ & 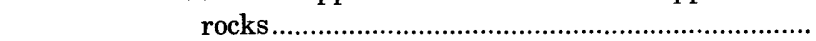 & A13 \\
\hline ntroduction... & A2 & Surficial deposits.... & A16 \\
\hline Regional analysis of the Midwestern Basins and Arches & & Hydrogeologic units... & A16 \\
\hline aquifer system .. & A2 & Surficial aquifer..... & A16 \\
\hline Objectives and approach.................. & $\mathrm{A} 2$ & Carbonate-rock aquifer..... & A19 \\
\hline Purpose a & & Regiona & A19 \\
\hline al & A2 & $\mathrm{Hy}$ & $\mathrm{A} 20$ \\
\hline Summary of & $\mathrm{A} 3$ & Potentiometric & $\mathrm{A} 21$ \\
\hline Acknov & A3 & Rec & $\mathrm{A} 21$ \\
\hline Physical set & A4 & Grour & $\mathrm{A} 25$ \\
\hline Extent of study area & A4 & Reg & $\mathrm{A} 25$ \\
\hline Physiography... & A5 & Sul & A31 \\
\hline Clim & A5 & Regic & $\mathrm{A} 34$ \\
\hline Iydrogeo & A5 & $\mathrm{Di}$ & A34 \\
\hline Geologic se & A5 & Hyc & A37 \\
\hline Bedroc & A7 & Relation of isotopic & \\
\hline 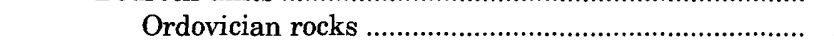 & A7 & regional flow.......... & A37 \\
\hline Silurian and Lower and Middle Devonian rocks ...... A & $\mathrm{A} 13$ & ind-water use & A41 \\
\hline & & & 44 \\
\hline
\end{tabular}

\section{ILLUSTRATIONS}

FiguREs 1-5. Maps of the Midwestern Basins and Arches Region showing:

1. Location of the area of data collection, study area, and structural arches and basins .................................. A4

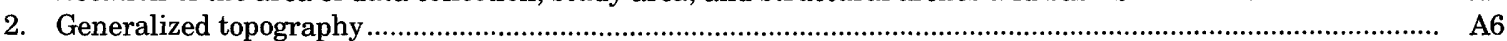

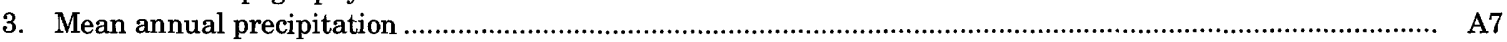

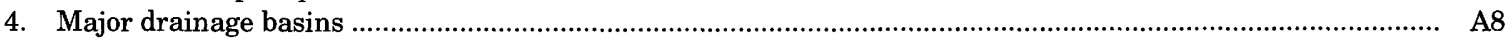

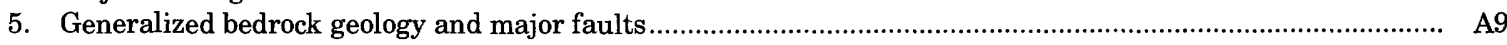

6. Generalized hydrogeologic sections A-A', B-B', and C-C', Midwestern Basins and Arches Region ............................... A10

7. Chart showing time- and rock-stratigraphic framework, nomenclature, and model layers for the Midwestern Basins and Arches Region

8-12. Maps of the Midwestern Basins and Arches Region showing:

8. Thickness of the basal confining unit of the carbonate-rock aquifer.............................................................. A12

9. Thickness of the carbonate-rock aquifer and approximate limit of ground water with dissolved-solids concentration greater than 10,000 milligrams per liter.................................................................... A14

10. Altitude of the top of the upper confining unit of the carbonate-rock aquifer ............................................... A15

11. Glacial deposits, extent of glaciation, and approximate location of the main stem and principal tributaries of the buried Teays-Mahomet River system …................................................................................. A17

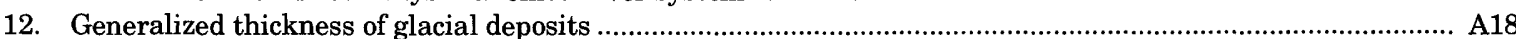

13. Conceptual hydrogeologic section showing the relation between local, intermediate, and regional flow......................... A20 14-22. Maps of the Midwestern Basins and Arches Region showing:

14. Generalized ground-water level configuration for the surficial aquifer...........................................................22

15. Potentiometric surface configuration for the carbonate-rock aquifer....................................................... A23

16. Calculated mean and mean sustained ground-water discharge to selected reaches along major streams in

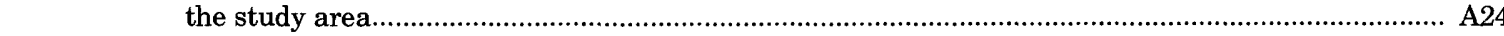

17. Model areas for regional and subregional ground-water-flow models........................................................... A26

18. Boundary conditions used in the regional ground-water-flow model of the surficial and carbonate-rock aquifers .....

19. Measured and simulated hydraulic heads for the carbonate-rock aquifer in the regional model.................... A29

20. Measured and simulated mean sustained ground-water discharge to selected stream reaches for the study

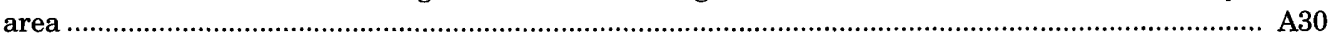

21. Recharge and discharge areas based on output from the calibrated ground-water-flow model.......................... A32

22. Ground-water-flow paths based on particle-tracking of regional ground-water flow...................................... A33 
23. Ground-water-flow paths based on particle-tracking results for a cross-sectional model representing regional groundwater flow from a regional recharge area in central-western Ohio to a regional discharge area at Lake Erie ... A34 24-28. Maps of the Midwestern Basins and Arches Region showing:

24. Distribution of dissolved-solids concentrations in the surficial aquifer.. A35

25. Distribution of dissolved-solids concentrations in the carbonate-rock aquifer..

26. Hydrochemical facies based on concentrations of major anions and cations in water from the surficial aquifer

27. Hydrochemical facies based on concentrations of major anions and cations in water from the carbonaterock aquifer.

29-30. Graphs showing:

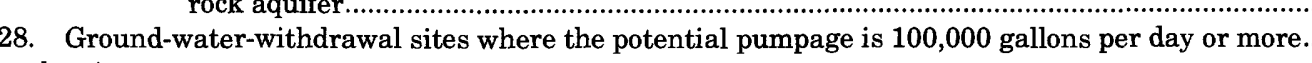

29. Total monthly ground-water withdrawals for parts of Indiana and Ohio in the Midwestern Basins and Arches Region

30. Total monthly ground-water use, by category, among users capable of withdrawing 100,000 gallons per day or more in parts of Indiana and Ohio in the Midwestern Basins and Arches Region...

\section{TABLES}

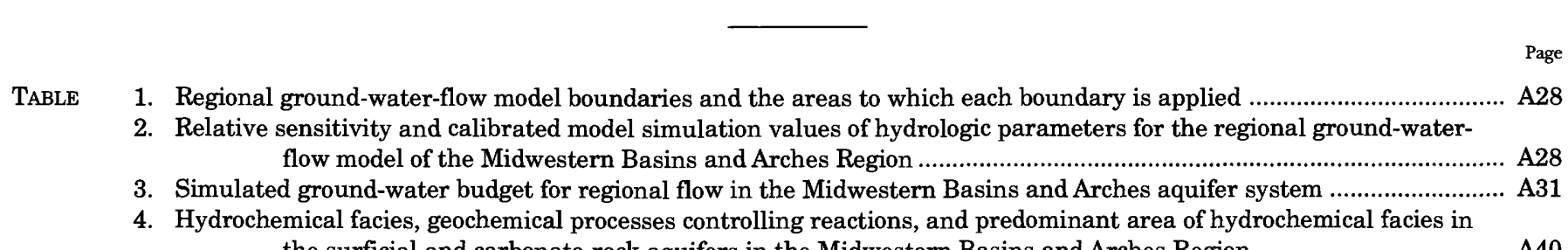
the surficial and carbonate-rock aquifers in the Midwestern Basins and Arches Region .....

\section{CONVERSION FACTORS, VERTICAL DATUM, AND ABBREVIATED WATER-QUALITY UNITS}

\begin{tabular}{rll}
\hline Multiply & By & To obtain \\
inch (in) & & \\
foot $(\mathrm{ft})$ & 25.4 & millimeter \\
mile $(\mathrm{mi})$ & 0.3048 & meter \\
square $\operatorname{mile}\left(\mathrm{mi}^{2}\right)$ & 1.609 & kilometer \\
inch per year $(\mathrm{in} / \mathrm{yr})$ & 2.590 & square kilometer \\
foot per day $(\mathrm{ft} / \mathrm{d})$ & 0.254 & millimeter per year \\
foot squared per day $\left(\mathrm{ft}^{2} / \mathrm{d}\right)$ & 0.3048 & meter per day \\
cubic feet per second $\left(\mathrm{ft}^{3} / \mathrm{s}\right)$ & 0.09290 & meter squared per day \\
gallon per minute $(\mathrm{gal} / \mathrm{min})$ & 0.02832 & liter per second \\
gallon per day $(\mathrm{gal} / \mathrm{d})$ & 0.06309 & liter per second \\
million gallons per day $(\mathrm{Mgal} / \mathrm{d})$ & 0.207 & liter per second per meter \\
\end{tabular}

Sea Level: In this report "sea level" refers to the National Geodetic Vertical Datum of 1929 (NGVD of 1929)—a geodetic datum derived from a general adjustment of the first-order level nets of both the United States and Canada, formerly called "Sea Level Datum of 1929".

Water-quality units used in this report: Concentrations of dissolved solids are given in milligrams per liter (mg/L), a unit expressing the concentration of chemical constituents as mass (millegrams) of solute per unit of volume (liter) of water. 
Stable isotope ratios are expressed as a departure of the ratio of two isotopes of an element in a given sample from the same ratio in an established standard; values are given in permil (parts per thousand).

Symbols and standards are the following:
$\delta^{13} \mathrm{C}$
Carbon-13/carbon-12 ratio, referenced to Pee Dee Formation of South Carolina
$\delta \mathrm{D}$ Deuterium/hydrogen ratio, referenced to SMOW (Standard Mean Ocean Water)
$\delta^{18} \mathrm{O}$ Oxygen-18/oxygen-16 ratio, referenced to SMOW
$\delta^{34} \mathrm{~S} \quad$ Sulfur-34/sulfer-32 ratio, referenced to Canyon Diablo meteorite standard 



\title{
REGIONAL AQUIFER-SYSTEM ANALYSIS-MIDWESTERN BASINS AND ARCHES
}

\author{
THE MIDWESTERN BASINS AND ARCHES \\ REGIONAL AQUIFER SYSTEM IN PARTS OF \\ INDIANA, OHIO, MICHIGAN, AND ILLINOIS- \\ SUMMARY
}

\author{
BY E.F. BUGLIOSI
}

\begin{abstract}
The Midwestern Basins and Arches aquifer system is composed of surficial deposits of Pleistocene and Holocene age and of Silurian and Devonian age carbonate rock in parts of Indiana, Illinois, Michigan, and Ohio. The study area encompasses a complex of structural arches-the Cincinnati, Findlay, and Kankakee Arches-and is bounded on the east, north and west by the Appalachian, Michigan and Illinois Basins, respectively. This report summarizes the major results of a 6-year study of this regional aquifer system. Because the rock units that compose the carbonate-rock aquifer are not truncated as they dip away from the arches and into the basins, the regional aquifer system has no definite stratigraphic boundaries. Thus, an area of "principal hydrologic interest" was defined that is bounded by the contact between carbonate bedrock and overlying shale bedrock of Upper Devonian age, and by various major water bodies. This area of intensive study includes about 44,000 square miles within a larger area of data collection that encompasses more than 90,000 square miles.

The hydrogeologic framework of the Midwestern Basins and Arches aquifer system is defined in terms of the extent and thickness of the lower confining unit, the carbonate-rock aquifer, the upper confining unit, and the surficial aquifer. The lower confining unit, which underlies the entire study area, consists of interbedded calcareous shales and limestone of Ordovician age that are much less impermeable than the overlying aquifer units. The lower confining unit ranges in thickens from an average of 200 feet in northwestern Indiana to more than 1,400 feet in central Ohio. The carbonate-rock aquifer consists primarily of limestone and dolomite of Silurian and Devonian age. The aquifer is absent in southwestern Ohio and southeastern Indiana along the axis of the Cincinnati Arch, but it is as much as 2,500 feet thick in southeastern Michigan at the edge of the Michigan Basin. The upper confining unit is composed of Upper Devonian and Mississippian calcareous shales but is present only along the lateral margins of the study area (a transitional area from arches to basins). The maximum thickness of the upper confining unit is about 700 feet in northeastern Ohio, at the edge of the Appalachian Basin. Glacial and alluvial deposits composing the surficial aquifer unconformably overlie 97 percent of the study area except in the extreme southeast, where the area is unglaciated. These deposits are more than 400 feet thick in northwestern Indiana, where they fill the buried, ancient Teays-Mahomet river system in the central part of the study area; however, they are only a few feet thick over bedrock highs, and are generally no greater than 50 feet thick in the southern and northeastern parts of the study area.

Ground water in the surficial aquifer is mostly unconfined but may be locally semiconfined or confined by layers of till. Ground water in
\end{abstract}

the carbonate-rock aquifer is confined where the aquifer is directly overlain by the upper confining unit along the margins of the structural basins; otherwise, ground water in the carbonate-rock aquifer is semiconfined by the surficial deposits. Ground-water flow in the aquifer system is primarily through secondary porosity, mainly through fractures within the upper 100 feet of the carbonate-rock aquifer.

Surface-water and ground-water data were used to characterize the components of the regional ground-water-flow system within the Midwestern Basins and Arches Region and to provide information to calibrate a regional ground-water-flow model of the system. The analysis of data from long-term streamflow records indicates that most base flow (50 to 97 percent among selected stream reaches) is from localized ground-water discharge to streams rather than from regional groundwater flow. Synoptically measured ground-water levels in July and August 1990 that represent long-term, steady-state conditions in the carbonate-rock aquifer show that the configuration of the potentiometric surface of the carbonate-rock aquifer generally mimics the topography within the area of principle hydrologic interest.

A two-layer, steady-state, numerical model representing the surficial and carbonate-rock aquifers was constructed to simulate regional ground-water flow within most of the area of principle hydrologic interest. The ground-water system was simulated to help interpret the rates and distribution of regional ground-water recharge and discharge. Modeling results indicate that virtually all recharge to the regional ground-water-flow system ( 99 percent) is from precipitation that enters the ground-water system at the water table and that about 78 percent of the ground water simulated in the regional aquifer system discharges to major streams within the study area, whereas less than 3 percent discharges to the Ohio River, Lake Erie, or downdip into the Illinois Basin. Additionally, model simulations indicate that recharge and discharge areas generally alternate within 10 miles except in the northeastern part of the study area, a former swamp that remains a large regional discharge area. The longest flow paths (about 50 miles long) are in the northeastern part of the study area, starting at a topographic high in central-western Ohio and terminating in Lake Erie.

Computer programs for tracking of ground-water-particles were used to indicate directions of regional ground-water flow. Particletracking results were used in conjunction with analyses of stable isotopes, carbon-14, and tritium concentrations of ground water from wells in the regional aquifer system to substantiate the concept of ground-water flow throughout the regional aquifer system. Carbon-14 data indicate that relatively old water (about 13,000 years old) is at the end of the longest flow paths (50 miles) near Lake Erie. In contrast, 
older waters (about 38,000-45,000 years old) were associated with ground-water-flow paths only 10 miles long in the Maumee River Basin, an indication that recharge is restricted in this area, probably by surficial lacustrine deposits.

Patterns of ground-water chemistry were defined by use of available data and by collection of additional information along regional ground-water-flow paths determined from the potentiometric-surface map of the carbonate-rock aquifer. The chemistry of ground water from wells that tap the regional aquifer system was classified into several types based on the percentage of the major cations and anions and by the concentration of dissolved solids in the water. The $\mathrm{Ca}-\mathrm{Mg}-\mathrm{HCO}_{3}$ and $\mathrm{Ca}-\mathrm{Mg}-\mathrm{SO}_{4}$ water types dominate the chemistry of ground water in the study area. The patterns of chemistry in water from wells within the carbonate-rock aquifers were compared and related to the geochemistry of the bedrock units within the Midwestern Basins and Arches Region. The chemistry of ground water throughout most of the study area is generally controlled by the dissolution of calcite and dolomite and produces $\mathrm{Ca}-\mathrm{Mg}-\mathrm{HCO}_{3}$ type waters except where the oxidation of pyrite is responsible for $\mathrm{Ca}-\mathrm{Mg}-\mathrm{SO}_{4}$ type waters.

The ground-water chemistry of the surficial aquifer is similar to that of the carbonate-rock aquifer within the study area. Dissolved-solids concentrations of ground water in the surficial aquifer range from about 100 to 2,600 milligrams per liter and those within the carbonaterock aquifer from about 100 to 3,800 milligrams per liter (although concentrations increase substantially as the carbonate-rocks dip into the structural basins).

Ground-water withdrawals within the study area were compiled from existing state water-use data reported by users capable of withdrawing more than 100,000 gallons per day. The ground-water-withdrawal estimates were used to determine the average amount of ground water that was potentially withdrawn in 1990 in the Indiana and Ohio parts of the study area; ground-water withdrawals were also categorized by the type of use. The reported monthly total groundwater withdrawal for parts of Indiana and Ohio within the study area for 1990 was 433 million gallons per day. Monthly totals of groundwater withdrawals indicate a seasonal trend of ground-water use. Almost three-fourths of reported ground-water use in 1990 was for public supply, similar to the proportion of public-supply use for the same area in 1980.

\section{INTRODUCTION}

As a result of a congressional mandate to develop quantitative appraisals of the nations most important regional aquifers (Sun, 1986), the U.S. Geological Survey (USGS) began the Regional Aquifer Systems Analysis (RASA) program in 1978. The objective of this program was the systematic study of the quantity and quality of the ground water in these regional aquifer systems.

In 1988, the RASA program began an analysis of the Midwestern Basins and Arches Region in part of the east-central portion of the United States (fig. 1). The surficial and carbonate-rock aquifers in this region are an economically significant supplement to surfacewater supply throughout the region and are economically and culturally important natural resources for this area. The regional aquifers supply water not only for human consumptive purposes, but also for agricultural, industrial, and recreational uses.

\section{REGIONAL ANALYSIS OF THE MIDWESTERN BASINS AND ARCHES AQUIFER SYSTEM}

\author{
OBJECTIVES AND APPROACH
}

The overall objective of the The Midwestern Basins and Arches RASA study was to develop an understanding of the hydrogeologic, hydraulic, and water-quality characteristics of the regional surficial and carbonaterock aquifers within their natural hydrogeologic boundaries. An additional objective was to create digital data bases of cartographic and spatially-registered information that could be used by regional planners and earth scientists to help manage the area's water resources. The study was designed primarily to make use of available data; however, additional data were collected where needed to supplement or clarify available information. The information was used to (1) describe the geometry (thickness, extent, and configuration of surfaces) of the surficial and carbonate-rock aquifers within the regional system, and types of deposits and rocks and their hydraulic properties; (2) determine the natural physical boundaries of the surficial and carbonate-rock aquifers; (3) describe regional ground-water flow and estimate regional recharge rates by the use of a finite-difference, three-dimensional, ground-water-flow model and base-flow analysis of unregulated streams within the region; (4) describe the quality of water in the surficial and carbonate-rock aquifers in terms of anion and cation facies and dissolved-solids trends and the relationship of the geochemistry to ground-water flow in the region; and (5) determine the current ground-water use.

\section{PURPOSE AND SCOPE OF PROFESSIONAL PAPERS 1423 A, B, AND C}

Professional Paper 1423 describes the hydrogeologic framework, hydrology, and geochemistry of the Midwestern Basins and Arches Region. Because regional ground-water flow is considered to be in a state of dynamic equilibrium (steady state) and because there are no apparent regional stresses on this system, comparative analysis of predevelopment and postdevelopment periods was not done.

The Professional Paper 1423 series consists of three papers:

Professional Paper 1423-A (this report) summarizes the basic aspects of study-area geology, hydrology, water quality, and geochemistry that are reported in more detail in the other papers,

Professional Paper 1423-B describes the hydrogeologic framework of the glacial and carbonaterock regional aquifer system (Casey, 1997). 
Professional Paper 1423-C discusses the hydrologic aspects of the glacial and carbonate-rock regional aquifer system, with emphasis on regional recharge and three-dimensional flow modeling; a separate section describes general water-quality trends and relates the isotopic composition of ground water to regional ground-water flow (Eberts and George, in press).

These and other reports prepared as part of the Midwestern Basins and Arches RASA project are indicated by an asterisk in the section "Selected References" of this report.

\section{SUMMARY OF PREVIOUS WORK}

Although ground water has become an increasingly important resource within the Midwestern Basins and Arches Region, comprehensive studies of the geology, hydrology, and water chemistry of the area are few. The bulk of the hydrologic literature for the region focuses on small areas, cities, or counties. One reason for the scarcity of regional information, especially with respect to the geohydrology, is that some bedrock units are discontinuous across the region from east to west (Shaver, 1985). Nevertheless, several reports have addressed specific aspects of parts of the Midwestern Basins and Arches RASA area.

The bedrock geology of the Midwestern Basins and Arches Region has been described only for parts of the area; however, a project team led by Shaver (1985) compiled a stratigraphic correlation of the Midwest Arches area that includes the Midwestern Basins and Arches RASA project area. Droste and others (1975), Droste and Shaver (1983 and 1985), and Ault and others (1976) discussed the orientation and paleogeography of the carbonate reef banks that underlie much of the study area in Indiana and central-western Ohio. The stratigraphy of Ohio was originally compiled and produced as a geologic map by Bownocker (1920): this map was not comprehensively updated until 1990 (Hull) and 1991 (Larsen).

Works by Norris and Fidler (1973) and Norris (1974), and by the Ohio Department of Natural Resources, Division of Water (1970) detailed the occurrence of water in the carbonate-rock aquifer in the western half of Ohio. The only other regional appraisal was a generalized report by Bloyd (1974), part of a USGS summary of the Nation's ground-water resources. Additionally, the Ohio Department of Natural Resources, Division of Water has issued a series of ground-water resources maps for many of the counties in Ohio at the scale of $1: 62,500$.
The regional hydrology of Indiana has been addressed somewhat systematically by the basinwide studies of ground water within the Whitewater River and Kankakee River Basins (Indiana Department of Natural Resources, 1988 and 1990, respectively). A statewide reconnaissance of available hydrologic information was compiled in 1982 (Geosciences Research Associates Inc.), and a ground-water atlas of Indiana compiled by the USGS shows the relation between surficial and bedrock aquifers within the State (Fenelon and others, 1994).

Regional water-quality in Indiana and Ohio has been addressed in several reports . A statewide compilation of water-quality information within bedrock and glacial aquifers in Indiana was produced by Geosciences Research Associates Inc. (1982) in cooperation with the U.S. Environmental Protection Agency. Several regional reports on the dissolved-solids concentration of water from bedrock aquifers have been produced for Indiana (Keller, 1983; Rupp and Pennington, 1987) and Ohio (Stout and others, 1932; Stith,1979). Comprehensive water-quality studies have been conducted on smaller parts of the Midwestern Basins and Arches Region, primarily in Ohio (Ohio Department of Natural Resources, Division of Water, 1970; Norris and Fidler, 1973; Norris, 1974; Breen and Dumouchelle, 1992). A state atlas of nitrate and pesticides in private wells in Ohio was compiled by Baker and others (1989).

\section{ACKNOWLEDGMENTS}

The author and staff of the Midwestern Basins and Arches RASA acknowledge the cooperation of state agencies in Ohio, Indiana, Michigan, and Illinois in providing geologic, hydrologic, and chemical data that enabled the completion of the project. The agencies include the Ohio, Indiana, Michigan, and Illinois Departments of Natural Resources, the Ohio Environmental Protection Agency, the Indiana Department of Environmental Conservation, and the Ohio and Indiana State Geological Surveys. Thomas Berg and Norman Hester, State Geologists of Ohio and Indiana, respectively, provided encouragement and access to many scientists on their respective staffs, who provided help in compiling and analyzing the geohydrologic framework of the surficial and carbonate-rock aquifers.

William Steen and Rebecca Petty of the Divisions of Water, Indiana and Ohio Departments of Natural Resources, respectively (and their staffs), and the staff at the Illinois Department of Natural Resources, Division of Water assisted in measuring more than 450 wells in July and August 1990 to produce a synoptic potentiometric-surface map of the carbonate-rock aquifer; in 


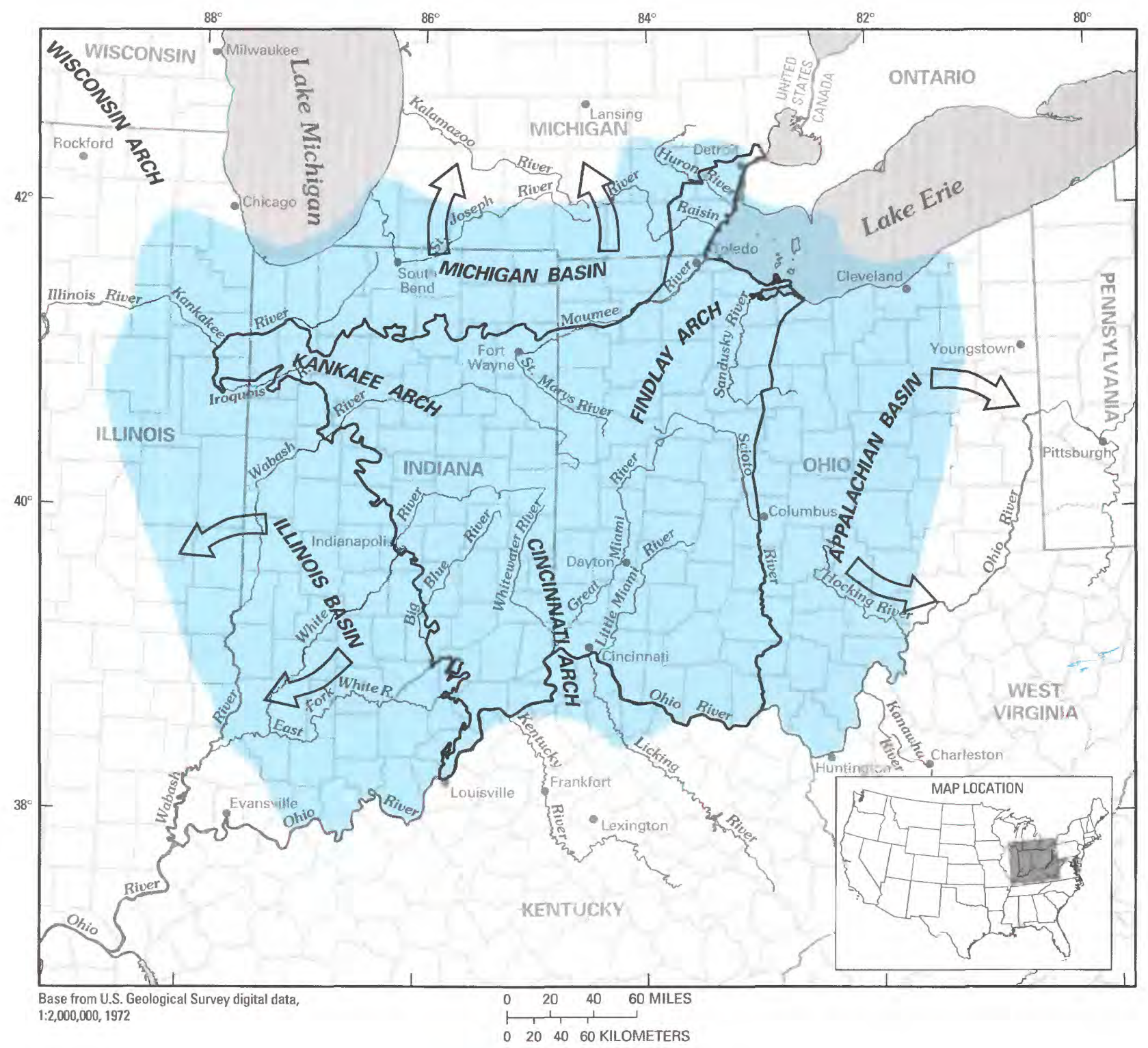

EXPLANATION

Data-collection area

Boundary of study area

Direction of dip into

structural basins

FIGURE 1.-Location of the Midwestern Basins and Arches Region, area of data collection, study area, and structural arches and basins.

addition, these persons provided access to hydrologic information that was instrumental in the formulation of a regional numerical ground-water-flow model of the Midwestern Basins and Arches Region.

The staff of the Midwestern Basins and Arches RASA project are also grateful to landowners of Ohio, Indiana, Michigan and Illinois for allowing measurement and sampling of wells.

\section{PHYSICAL SETTING}

\section{EXTENT OF STUDY AREA}

The Midwestern Basins and Arches RASA study area encompasses a complex of three structural arches-the Cincinnati, Findlay, and Kankakee Arches 
in Ohio, Indiana, and parts of Michigan and Illinois-and is surrounded by three structural basins-the Michigan, Appalachian, and Illinois Basins (fig. 1). The area's location within an arch and basin complex dictates that the lateral boundaries of the regional carbonate-rock aquifer are not truncated by geologic strata as they would be in a single structural basin or in a continental shelf setting. Therefore, the boundary of the Midwestern Basins and Arches RASA study area is a combination of hydrogeologic, hydrologic, and chemical boundaries that enclose an area of approximately $44,000 \mathrm{mi}^{2}$ (fig. 1).

The boundary of the study area is coincident with either major surface-water bodies (large rivers or Lake Erie) or the contact between Devonian limestones and younger, overlying Devonian shales. An additional boundary defined for the study was the line between ground water with a dissolved-solids concentration less than $10,000 \mathrm{mg} / \mathrm{L}$ and water that is more saline within the carbonate-rock aquifer units that dip into each of the three structural basins; this boundary was delineated to aid in ground-water-flow modeling (see the section "Regional Ground-water Flow").

Additional data were collected beyond the study area to define (1) the geometry of the geologic units and (2) the physiochemical limit of the fresh ground water as the regional ground-water-flow system extends into the structural basins (fig. 1). This larger area represents the geographical extent for which information was obtained to determine the geometry and chemistry of the regional aquifer system in the Midwestern Basins and Arches Region. Most of the analyses discussed herein, however, were limited to the study area because that is the area of active, fresh ground-water flow in the regional system and because little hydrologic information is available for the carbonate-rock aquifer outside the study area.

\section{PHYSIOGRAPHY}

The study area is mostly within the Midwestern Basin and Arches Region defined by the American Association of Petroleum Geologists (Shaver, 1985). This area lies within the Central Lowlands Physiographic Province east of the Mississippi River (Fenneman, 1938). Erosion has reduced the low, broad bedrock arches to a fairly flat plain throughout most of the area, with the exception of: (1) the southern part of the region, which has been dissected by numerous streams, and (2) two topographically high areas, one in central-western Ohio and another along the Ohio-Indiana state line (fig. 2).
Land-surface altitude in the area ranges from more than 1,400 ft near the central-western Ohio to about 500 $\mathrm{ft}$ near the Ohio River (USGS 1:500,000 state topographic maps) (fig. 2). A broad lowland along the ancestral glacial Lake Maumee and Lake Whittlesey plains (Flint, 1971, fig. 26-b) is the former "Black Swamp", an area of peat-like soil that has been drained by numerous ditches since the late 1800's (Kaatz, 1952). About $24 \mathrm{mi}$ of coastline along the southwestern part of Lake Erie is included in the study area (fig. 1).

\section{CLIMATE}

The Midwestern Basins and Arches Region has a humid, temperate climate and a weather pattern dominated by pressure cells emanating either from the Gulf of Mexico (bringing warm, moisture-laden air northward up the Mississippi and Ohio River Valleys) or from the Canadian interior (bringing cooler, drier air).

The source of freshwater in the Midwestern Basins and Arches Region is precipitation, primarily as rain and snow, and secondarily as hail and dew. The mean annual precipitation, computed from National Oceanographic and Atmospheric Administration (NOAA) records of meteorological stations with at least 50 years of data, ranges from 33 to 43 in (fig. 3). Precipitation patterns are probably influenced by evaporation from lakes Erie and Michigan, and (or) flow of moist air northeastward through the Ohio River Valley.

Parts of three major river systems drain the study area: the Ohio River drainage (Wabash River, White River, East Fork White River, Great Miami River, Little Miami River, and Scioto River), the St. Lawrence River drainage (Maumee River, Sandusky River, River Rasin, and Huron River), and the Upper Mississippi River drainage (fig. 4). Additionally, a divide within the study area separates water draining to the Atlantic Ocean through the Great Lakes and the St. Lawrence Seaway from water draining to the Gulf of Mexico through the Ohio and Mississippi Rivers (fig. 4).

\section{HYDROGEOLOGY}

\section{GEOLOGIC SETTING}

The geology of the Midwestern Basin and Arches region is composed of sedimentary rocks that underlie the area and range in age from Cambrian through Permian. However, only Late Ordovician through Pennsylvanian rocks crop out within the study area (fig. 5). The units dip away from the crests of the arches toward the three structural basins, thickening differently within 


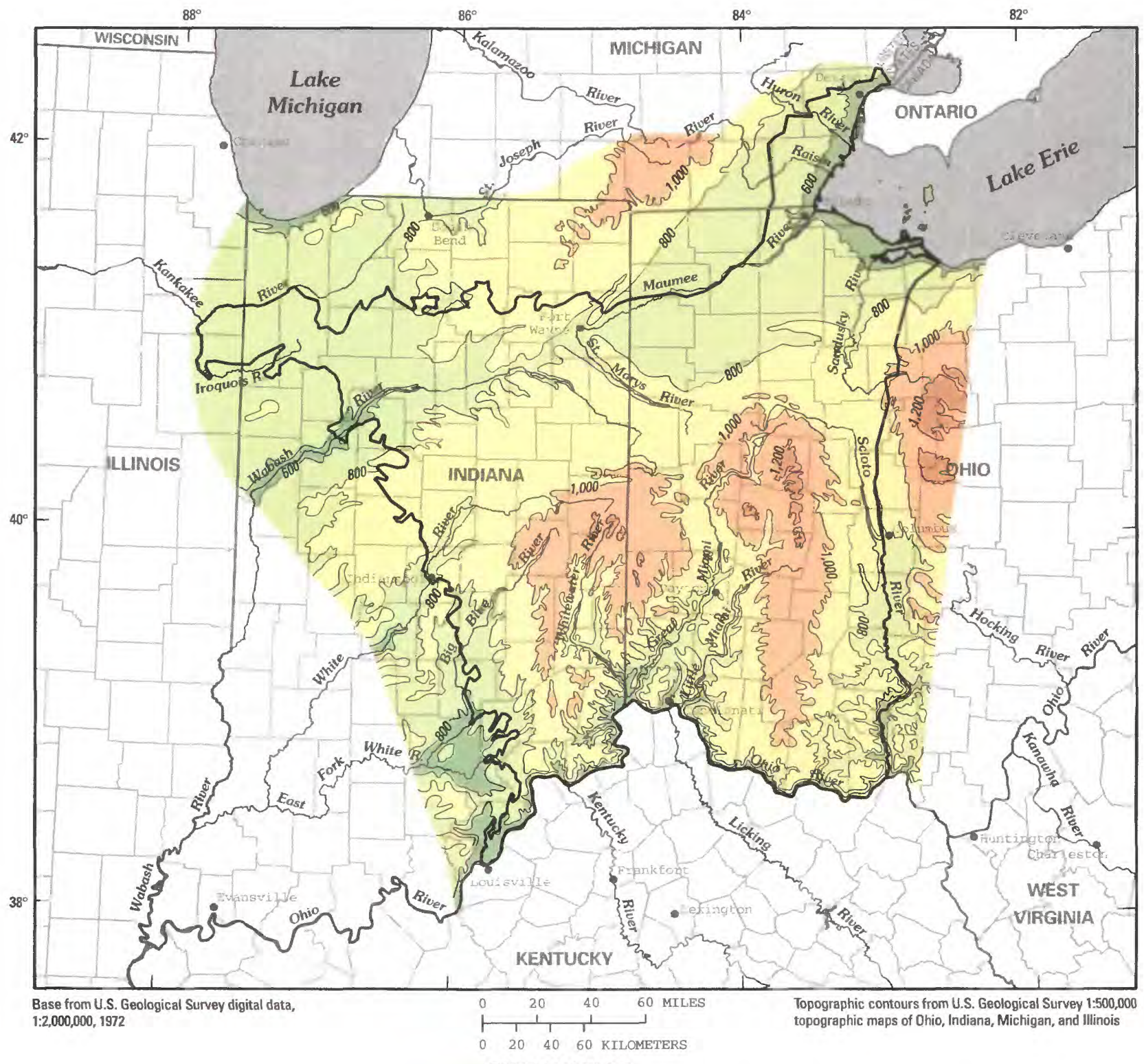

EXPLANATION

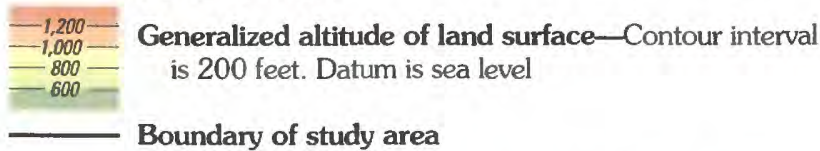

Figure 2.-Generalized topography of the Midwestern Basins and Arches Region.

each basin depending upon the structural and depositional history of that basin (figs. 5 and 6). The degree of dip ranges from less than $1^{\circ}$ on the flanks of the Arches to greater than $5^{\circ}$ toward the center of the structural basins (G.D. Casey, U. S. Geological Survey, written commun, 1994). Depositional environments within the structural basins, where restriction of inter- and intrabasin circulation differed, produced various accumulations of sediments within each basin. The different pat- tern of circulation within the basins, caused by restrictions in inflow into these basins, also affected the type of sediments deposited, especially the types and amounts of evaporites. Most of the tectonic events that led to the formation of the arches and basins within the region occurred from at least Early Ordovician through Permian time and include the Taconic, Acadian, Alleghey, and Ouachita orogenies (Beaumont and others, 1988). 


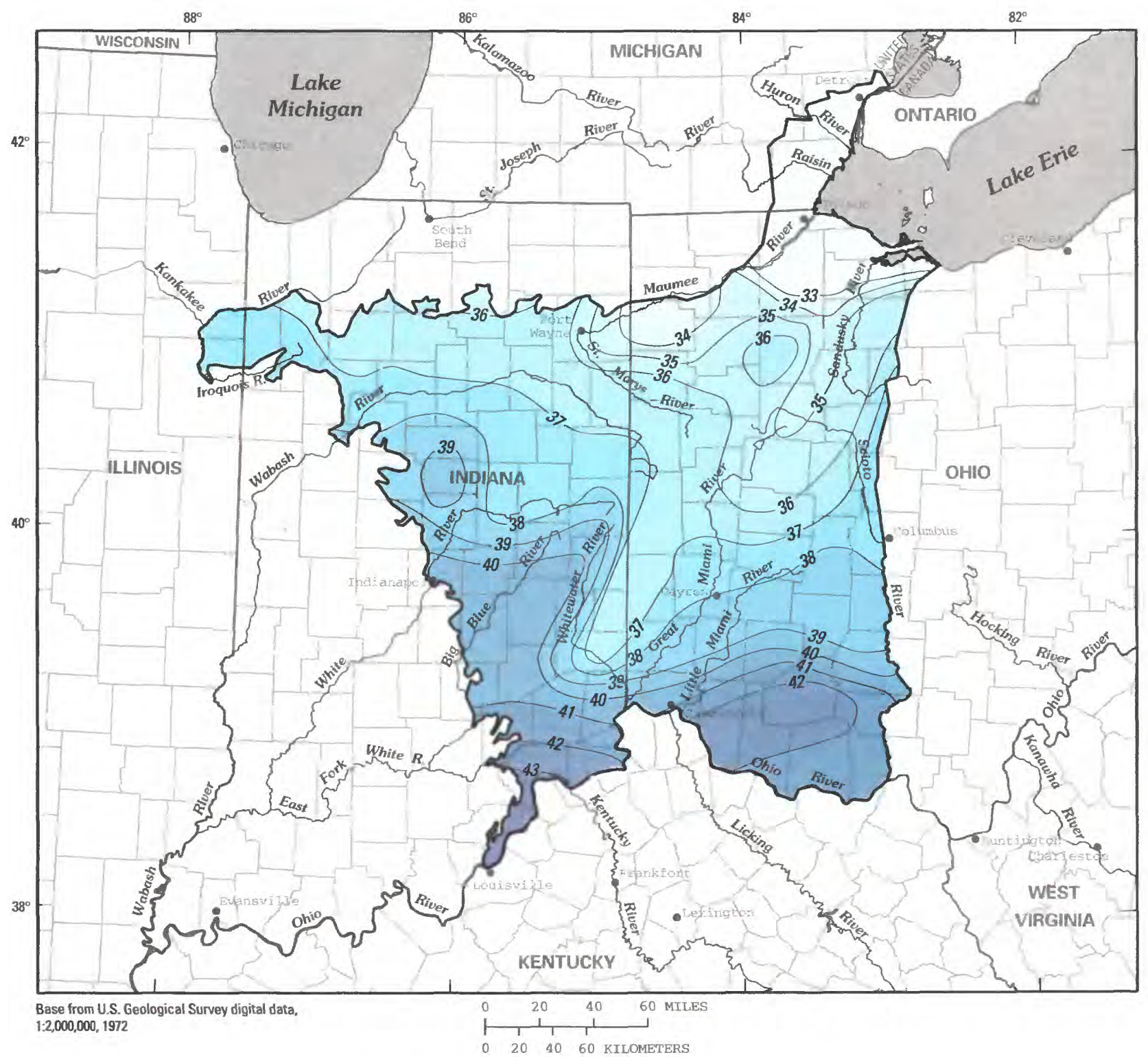

\section{EXPLANATION}

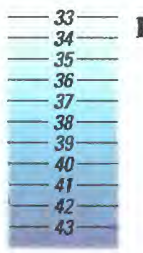

Equal mean annual precipitation, in inches-

Interval is 1 inch. Data from meteorological stations with greater than 50 years of record

Fre 3.-Mean annual precipitation in the area of principal hydrologic interest, Midwestern Basins and Arches Region

\section{BEDROCK UNITS}

\section{ORDOVICIAN ROCKS}

The basal confining unit of the carbonate-rock aquifer consists of Upper Ordovician units that unconformably overlie the Trenton Limestone in Indiana and northwestern and central Ohio (Gray, 1972; Janssens, 1977; Droste and Shaver, 1985), and are overlain unconformably by the Sexton Creek Limestone or Brassfield Limestone and Cataract Formation of Silurian age (LaFerriere and others, 1986) (fig. 7). The rocks that comprise the basal confining unit are the Maquoketa 


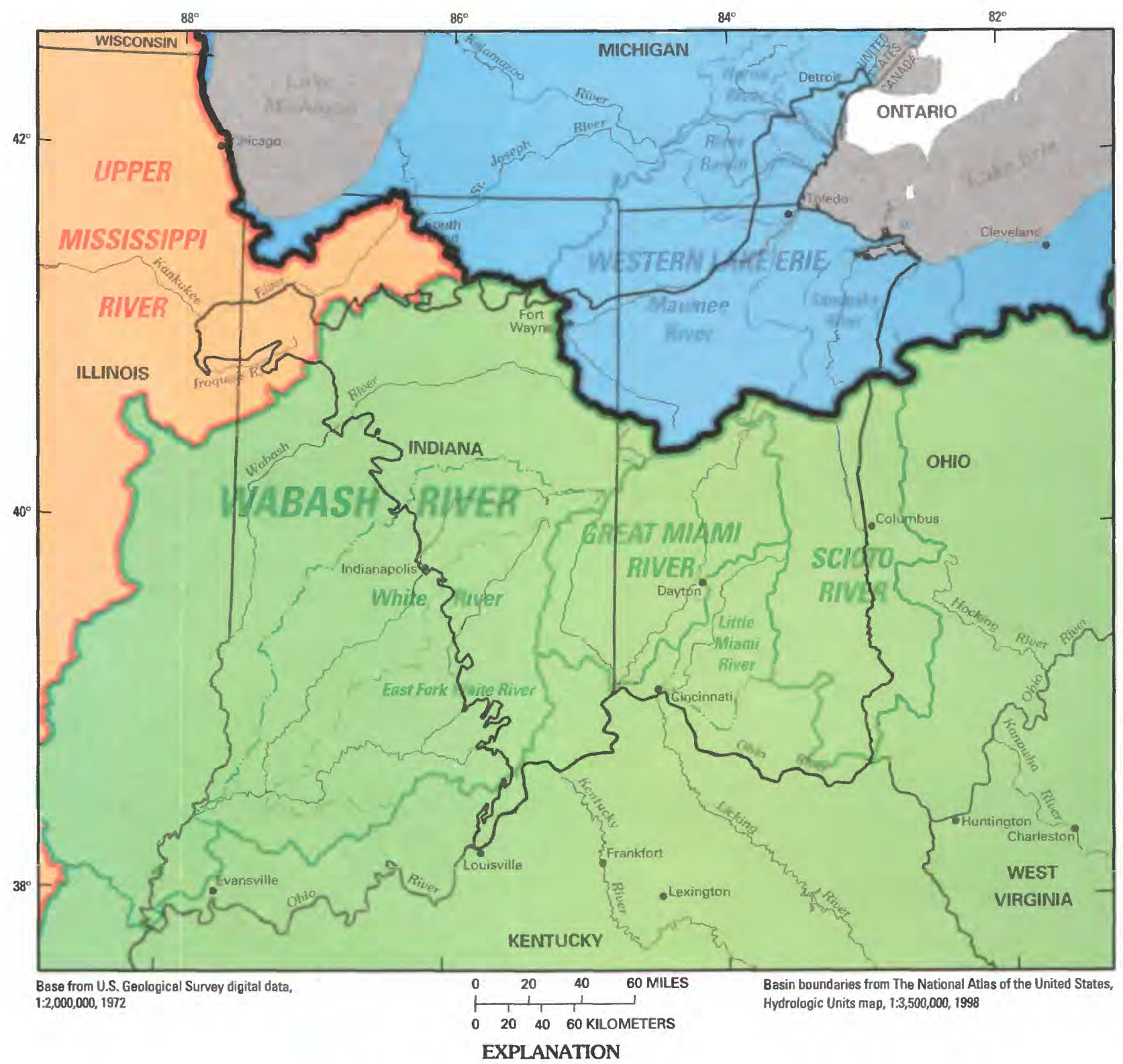

\section{Regional drainage basins}

St. Lawrence River-Great Lakes

Upper Mississippi River

Ohio River

Major surface-water divide-Separates surface water that flows northward toward the Atlantic Ocean from surface water that flows southward toward the Gulf of Mexico

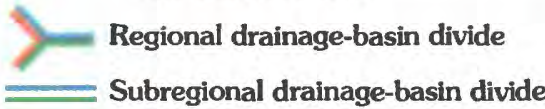

\section{$\equiv$ 三 Other drainage basin divides}

\section{Boundary of study area}

FIGURE 4.-Major drainage basins in the Midwestern Basins and Arches Region. 


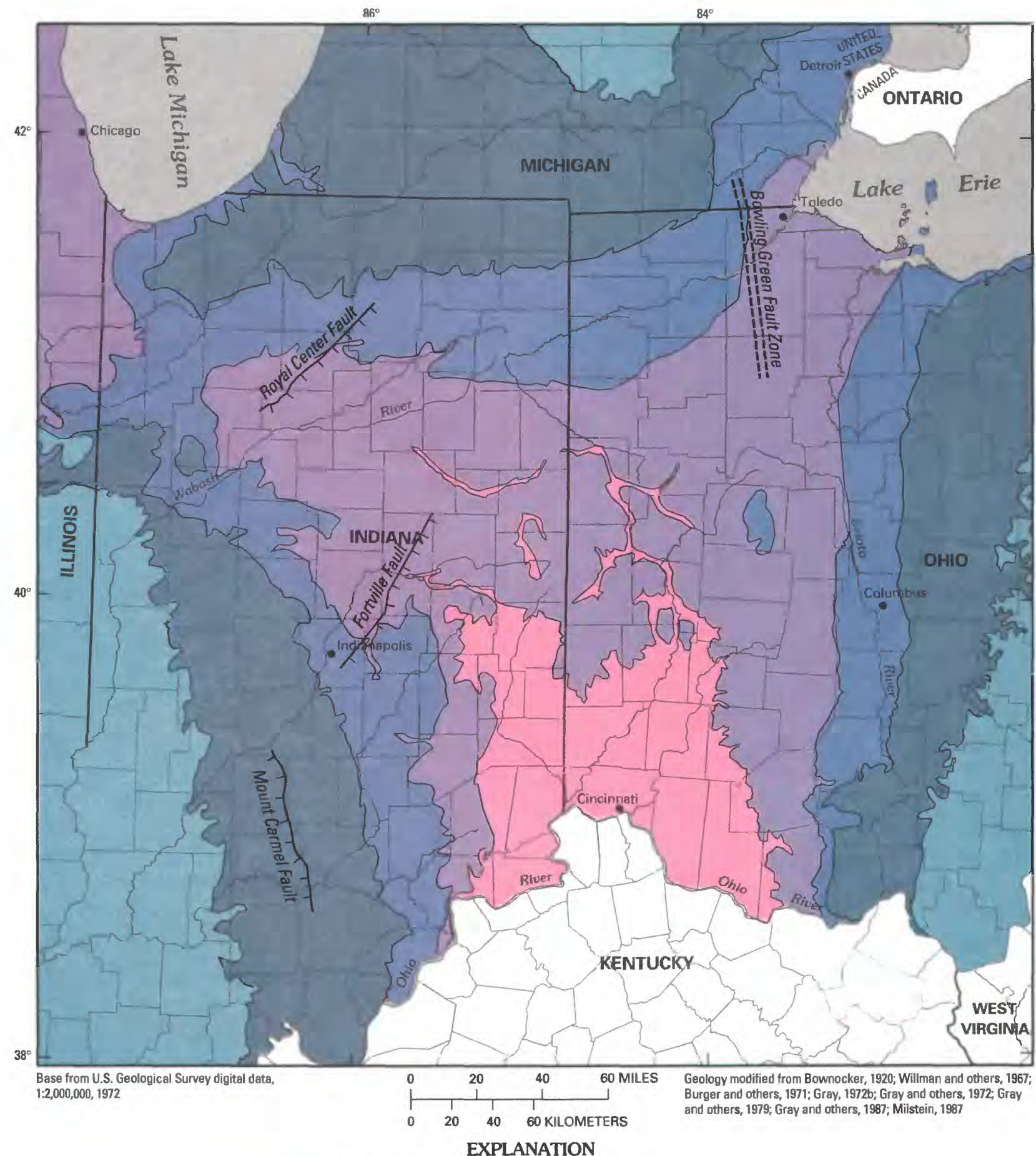

Geologic time units

Contact

$\square$ Pennsylvanian
$\square$ Mississippian
$\square$ Devonian
$\square$ Silurian
$\square$ Ordovician

=ニニ= Bowling Green Fault ZoneFrom Van Wagner, 1988

Fault-Locations from various sources. Hachures on downthrown side

FIGURE 5.-Generalized bedrock geology and locations of major faults in the Midwestern Basins and Arches Region. 

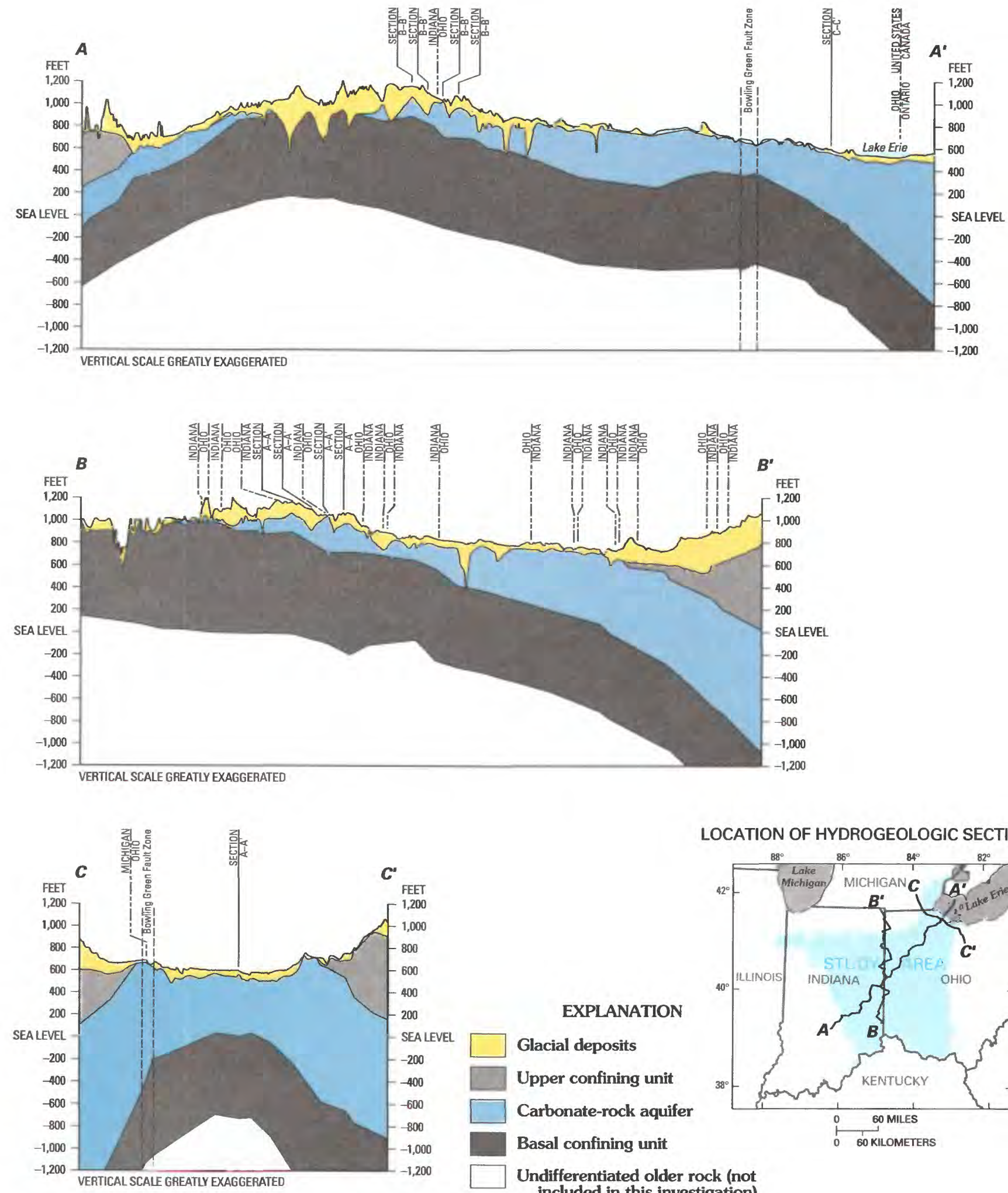

\section{LOCATION OF HYDROGEOLOGIC SECTIONS}

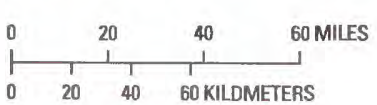

\section{EXPLANATION}

Glacial deposits

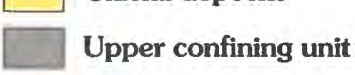

Basal confining unit

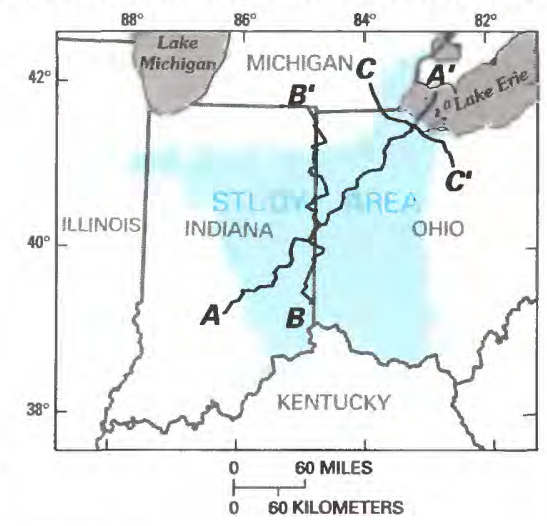

Undifferentiated older rock (not included in this investigation)

\section{Contact \\ A $A^{\prime}$ 'Trace of hydrogeologic section}

FIGURE 6.-Generalized hydrogeologic sections A-A', B-B', and C-C'; Midwestern Basins and Arches Region (modified from Casey, 1997). 


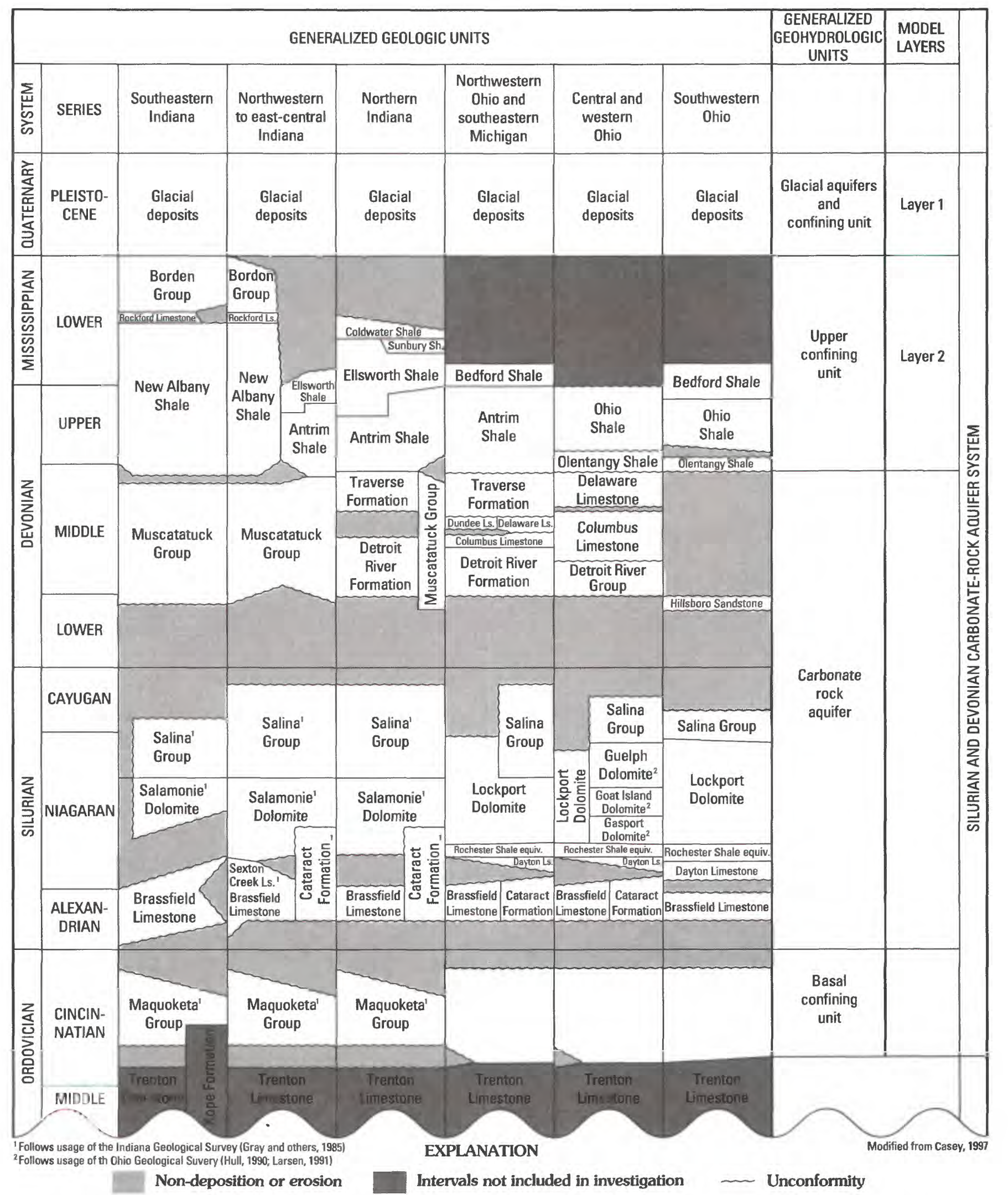

FIGURE 7.-Time- and rock-stratigraphic framework, nomenclature, and model layers for the Midwestern Basins and Arches Region. 
Group (Indiana usage) and undifferentiated Cincinnatian rocks (Ohio usage) and are similar time-stratigraphic rocks. The rocks that comprise the basal confining unit generally are composed of grey calcareous shale with alternating limestone layers in the upper 20 percent of the unit (Gray, 1972).

The thickness of the Ordovician rocks that comprise the basal confining unit (Maquoketa Group and undifferentiated Cincinnatian rocks) ranges from $200 \mathrm{ft}$ in northwestern Indiana to about 1,000 ft $25 \mathrm{mi}$ east of the Ohio-Indiana border, gradually thickening to more than $1,200 \mathrm{ft}$ as they dip into the Appalachian Basin and to more than $600 \mathrm{ft}$ as they dip into the Michigan Basin (fig. 8). In southeastern Indiana and southwestern Ohio the basal confining unit thins to less than $700 \mathrm{ft}$ near the updip limit of rock of Silurian age and to less than $100 \mathrm{ft}$ near the Ohio River (Casey, 1997) (fig. 8).

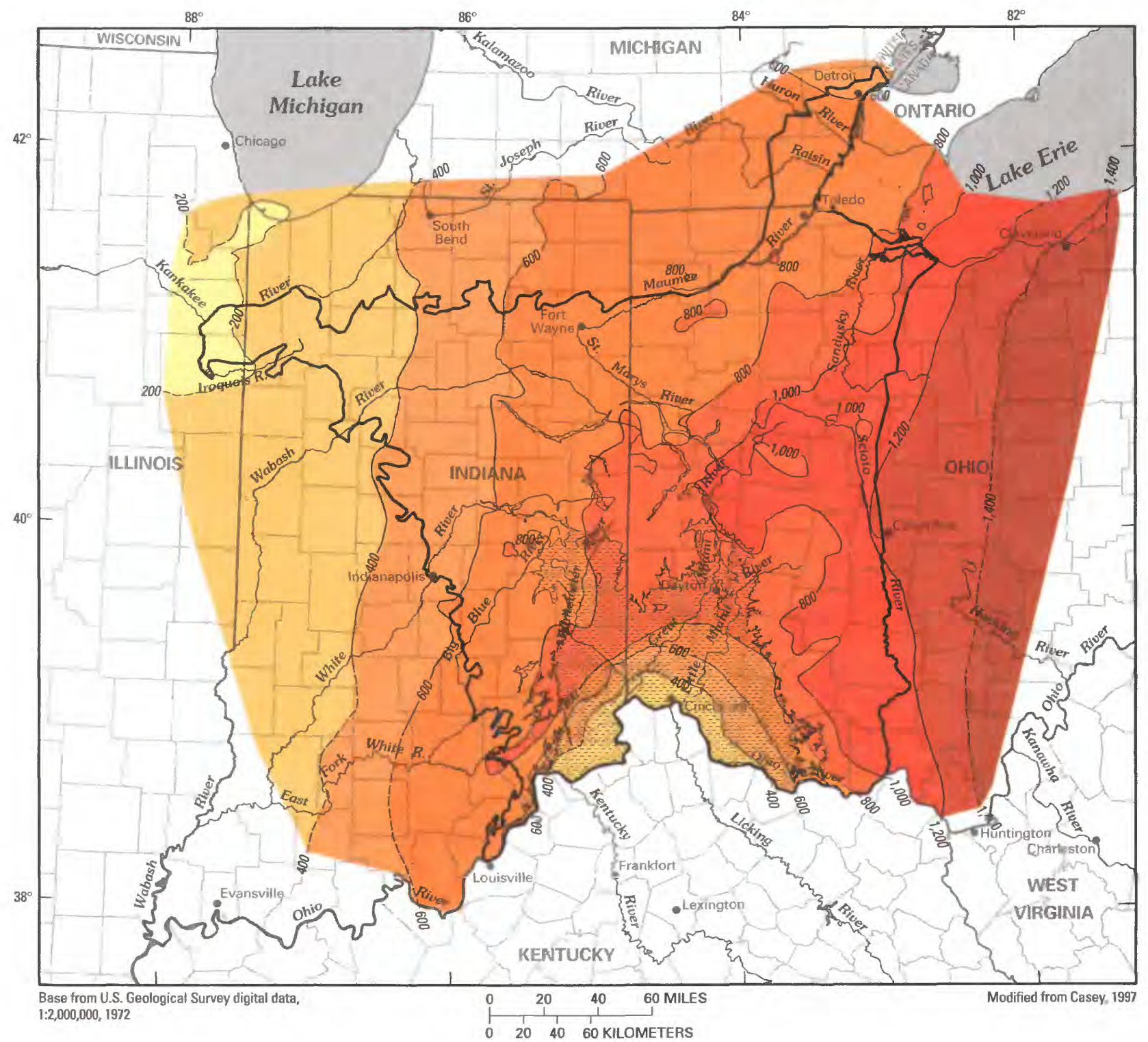

EXPLANATION

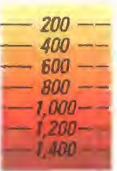

Thickness of the basal confining unitLines of equal thickness dashed where inferred. Interval 200 feet. Darker colors indicate greater thickness
Subcrop of Ordovician rocks beneath surfical deposits

Boundary of study area

FIGURE 8,-Thickness of the basal confining unit of the carbonate-rock aquifer, Midwestern Basins and Arches Region. 


\section{SILURIAN AND LOWER AND MIDDLE DEVONIAN ROCKS}

The Carbonate-rock aquifer throughout the study area is composed of Silurian and Devonian bedrock units (fig. 7). The physical characteristics of these rocks are principally a result of tectonic forces that resulted in basin subsidence and arch formation in the Midwestern Basins and Arches Region. The depositional environments within each of the structural basins and near the arches affected the accumulation of carbonate sediment and resulted in different types of these deposits, for example, reef-bank and reef flank deposits that differ somewhat from the pelagic, carbonate deposits elsewhere within the study area. Beds of gypsum and other evaporitic deposits are present locally in northwestern Ohio; otherwise, the majority of the rocks that compose the carbonate-rock aquifer are either limestone or dolomite with widely-scattered, discontinuous evaporitic deposits.

The Silurian rocks that overlie the Ordovician rocks are composed of sediment that was deposited during Alexandrian, Niagaran and Cayugan time (fig. 7). The Cataract Formation directly overlies the basal confining unit in northwestern Indiana and eastward to centralwestern Ohio. In parts of western and northern Indiana, the Ordovician rocks are overlain by the Sexton Creek Limestone, and in southeastern Indiana and southwestern Ohio by the Brassfield Limestone. These rocks, in turn, are unconformably overlain by the Salamonie Dolomite in Indiana and the Dayton Limestone in Ohio (fig. 7). During late Niagaran and early Cayugan time the rocks representing the Salina Group were deposited in Indiana, and from mid Niagran to early Cayugan time the rocks representing the Lockport Group and Salina Group were deposited in Ohio. The Rochester Shale Equivalent is interbedded between the underlying Brassfield Limestone, Cataract Formation, and the Dayton Limestone and the overlying Lockport Group in Ohio. The Silurian carbonate rocks are composed of dolomite, argillaceous dolomite, and limestone, whereas the relatively thin Rochester Shale Equivalent is composed of interbedded shale, limestone, and dolomite.

The Devonian rocks that make up the upper portion of the carbonate-rock aquifer were deposited during the later part of Lower Devonian, and during Middle Devonian time (fig. 7). These rocks are somewhat thinner than the Silurian-aged rocks due to uplift and subsequent erosion, especially along the crests of the arches in the study area. The Silurian and Devonian rocks are separated by a major unconformity during late Silurian (Cayugan) and Lower Devonian time. The rocks of Middle Devonian age are composed of the Detroit River Formation or Detroit River Group in northern Indiana, northwestern, and central-western Ohio, and are over- lain by the Delaware Limestone and Columbus Limestone in northwestern and central-western Ohio, respectively. In most of northern Indiana the Middle Devonian rocks are overlain by the Traverse Formation, but in northwestern, east-central, and southeastern and part of northern Indiana, the entire Middle Devonian carbonate sequence is classified as the Muscatatuck Group (Shaver, 1974).

The rock units of Silurian and Devonian age that make up the carbonate-rock aquifer in the Midwestern Basins and Arches Region are offset by several faults within the study area (figs. 5 and 6). The Royal Center, Fortville, and Mount Carmel Faults cut the carbonaterock units of Silurian and Devonian age in Indiana along the northeastern and eastern edge of the Illinois Basin, and represent movement during Mississippian and Pennsylvanian time (Melhorn and Smith, 1959; Shaver and Austin, 1972). The faults are normal and have maximum displacements of less than $200 \mathrm{ft}$. In Ohio, the Bowling Green Fault Zone is composed of multiple faults that have been mapped within this zone (VanWagner, 1988). Movement along this zone is uncertain, occurring either during early Paleozoic time or as recently as Cenozoic time (Onasch and Kahle, 1991) and vertical displacement along these faults ranges from 90 $-300 \mathrm{ft}$ (VanWagner, 1988). Nowhere in the Midwestern Basins and Arches Region do these faults juxtapose a confining unit alongside the carbonate-rock aquifer, therefore there is no regional disruption of groundwater flow by these faults.

The thickness of the rocks of Silurian and Devonian age that make up the carbonate-rock aquifer range from $0 \mathrm{ft}$ in the south-central part of the study area, at the contact with the rocks of Ordovician age in southeast Indiana and southwest Ohio, to more than $2,500 \mathrm{ft}$ in southeastern Michigan as the units dip northwestward into the Michigan Basin. Generally the carbonate-rock aquifer thins where it crops out along the crests of the Arches and thickens downdip into the Appalachian, Michigan and Illinois Basins. The rate and degree of thickening however, differs within each basin (fig. 9). The units that make up the carbonate-rock aquifer also are absent where the buried ancient Teays-Mahomet River System completely dissects these units and is incised into the basal confining unit of Ordovician age within the study area. The greatest thickness of the carbonate-rock aquifer within the Midwestern Basins and Arches Region is along the east and west flanks of the Findlay Arch (figs. 1 and 9).

\section{MIDDLE AND UPPER DEVONIAN AND MISSISSIPPIAN ROCKS}

The rocks that overlie and confine the carbonaterock aquifer consist of shales of late Middle and Upper 


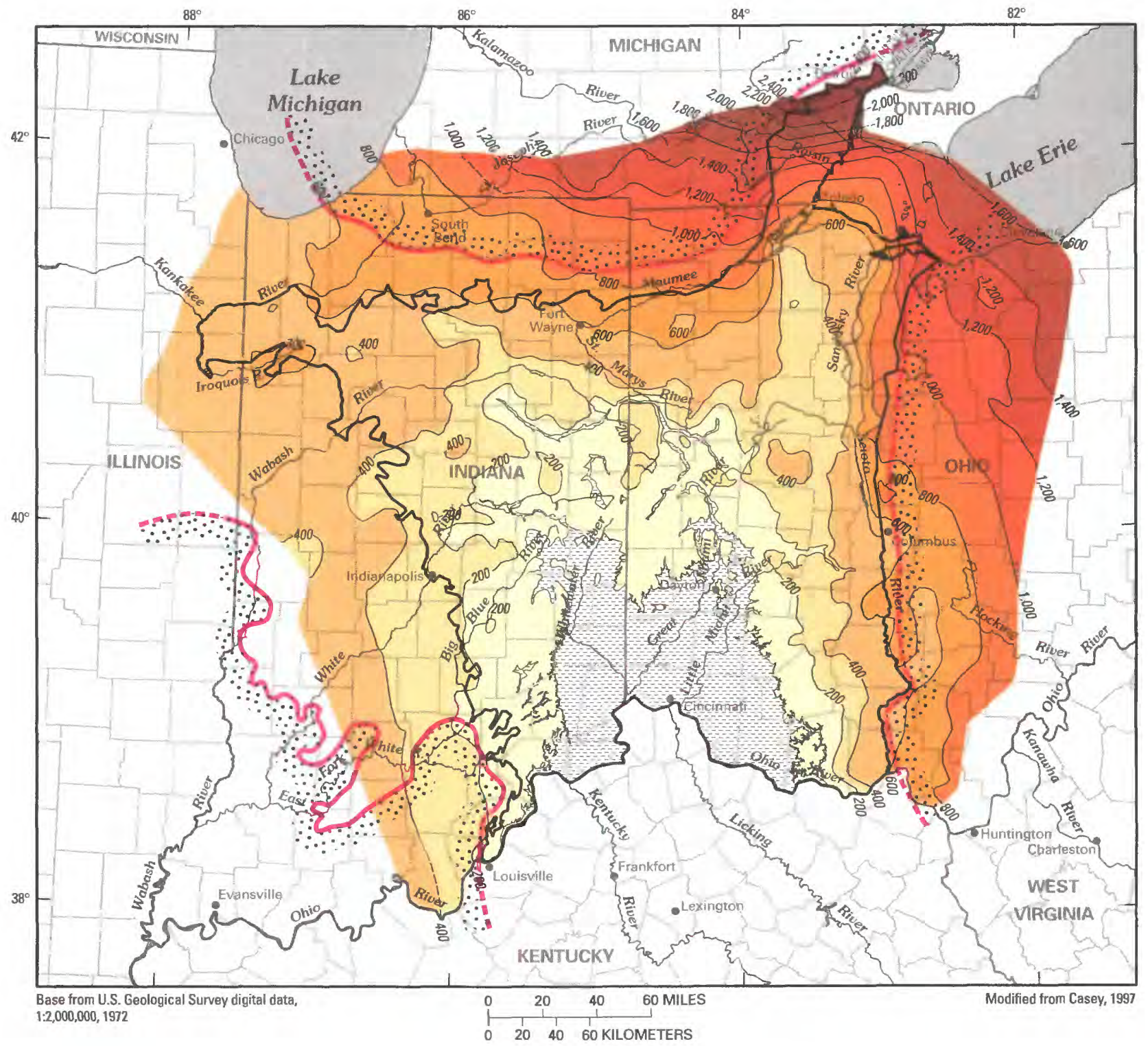

EXPLANATION

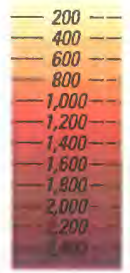

Thickness of the carbonate-rock aquifer-Lines of equal thickness dashed where inferred. Interval 200 feet. Darker colors indicate greater thickness

\section{Approximate limit of dissolved-solids concentration greater than 10,000 milligrams per liter-Dashed where inferred. Pattern along limit indicates side with higher concentration}

Subcrop of Ordovician rocks beneath surficial deposits

Boundary of study area

FIGURE 9.-Thickness of the carbonate-rock aquifer and approximate limit of ground water with dissolved-solids concentration greater than 10,000 milligrams per liter in the Midwestern Basins and Arches Region.

Devonian age, and shales and siltstones of Lower Mississippian age. It is important to understand, however, that these rocks have been eroded over most of the study area (figs. 6 and 10), and that they confine only a small part of the carbonate-rock aquifer around the flanks of the Arches, where the carbonate-rock-aquifer units dip into each structural basin (fig. 10). The tectonic forces that caused the depositional environments during late Middle Devonian, Upper Devonian, and Lower Mississippian time were a result of the continued collision between the North American craton and the Avalon terrane, known as the Acadian orogeny (Ettensohn, 


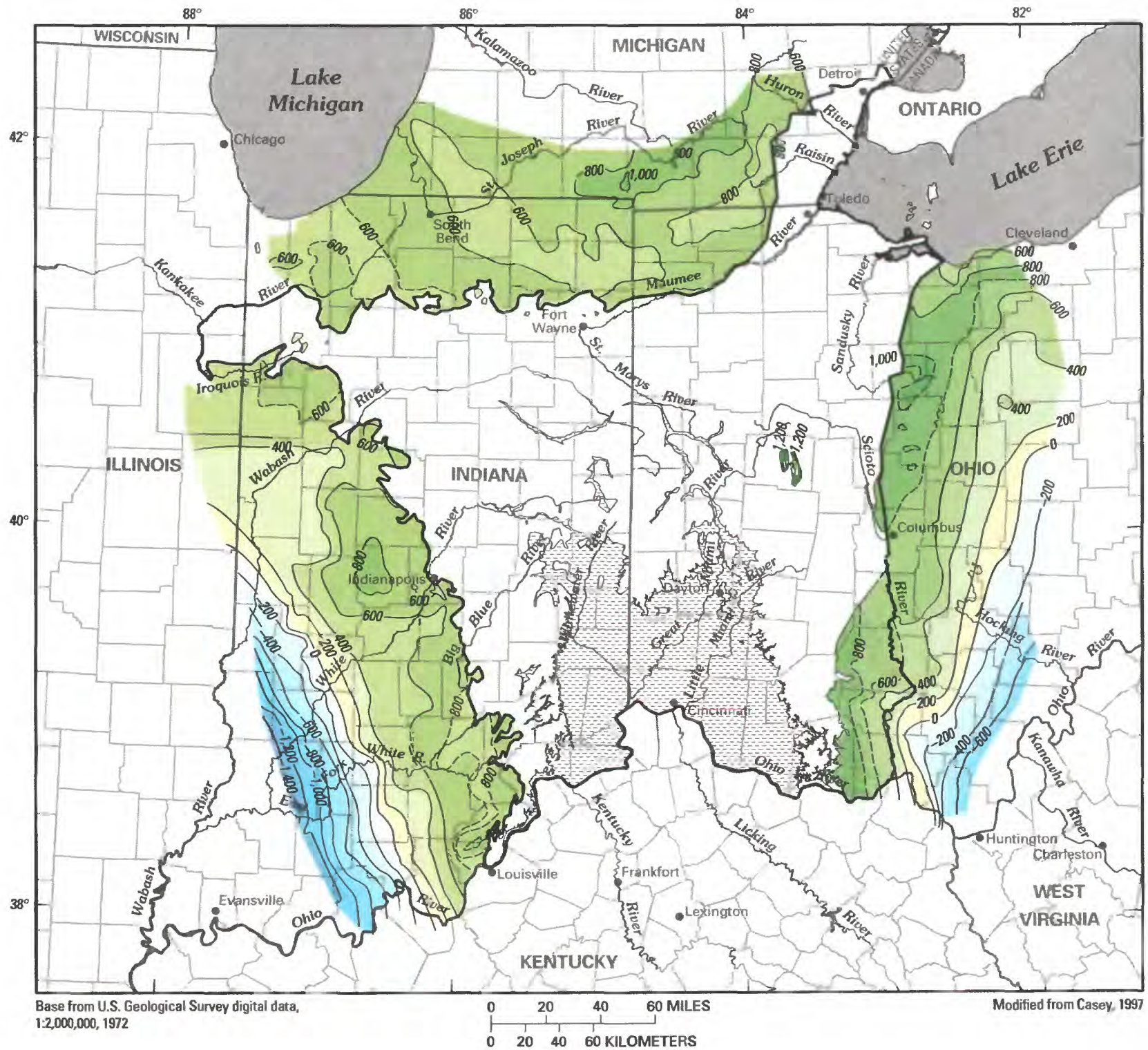

EXPLANATION

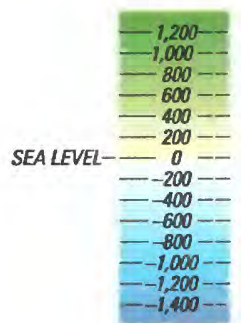

Altitude of the top of the upper confining unit-Contour interval 200 feet. Dashed where inferred. Datum is sea level. Darker greens indicate greater elevation above sea level; darker blues indicate greater depth below sea level

FIGURE 10.-Altitude of the top of the upper confining unit of the carbonate-rock aquifer in the Midwestern Basins and Arches Region.

1985). In northern Indiana, these rocks consist of the Antrim, Ellsworth, Sunbury, and Coldwater Shales. South of the Kankakee Arch, in southeastern Indiana, the New Albany Shale is equivalent to the Antrim, Ellsworth, and Sunbury Shales. In Ohio, the rocks which comprise the upper confining unit south of the Findlay Arch are the Olentangy, Ohio, and Bedford Shales; north of the Findlay Arch the upper confining unit is grouped into the Antrim Shale and the Bedford Shale. 
The rock units of Devonian age that make up the upper confining unit of the carbonate-rock aquifer (fig. 7) are generally composed of clay-rich shale, in some areas fissile, and occasionally interlayered with argillaceous material, thin sheets of micaceous sandstone, and pyrite (Hoover, 1960). Natural gas is produced in moderate quantities from units such as the Ohio Shale and its equivalent (Janssens and de Witt, 1976). The Mississippian units are generally silty shales or argillaceous siltstones and shales with some fine grained sandstones and interbedded, discontinuous limestone lenses (Shaver and others, 1986).

The thickness of the upper confining unit of the carbonate-rock aquifer system ranges from $0 \mathrm{ft}$ along the crests of the Kankakee, Findlay and Cincinnati Arches where the upper confining unit has been subjected to several extensive periods of erosion, to more than 1,000 $\mathrm{ft}$ on the western flank of the Appalachian Basin and the southern flank of the Michigan Basin. In general, the thickness of the upper confining unit increases from the contact between the Devonian carbonates and the updip edge of the Devonian shales and thickens downdip toward the three structural basins. The upper confining unit is cut by only one major fault, the Mount Carmel Fault, in Indiana. Vertical displacement along this fault is generally thought to be less than 200 feet; therefore, the confining unit does not appear to be breached along the Mount Carmel Fault. Additionally, there is no evidence that there is any perturbation of ground-water-flow patterns in the carbonate-rock aquifer associated with this fault.

\section{SURFICIAL DEPOSITS}

The surficial deposits of the Midwestern Basins and Arches Region include the glacial deposits that cover most of the study area and alluvium that is concentrated along stream valleys. More than 95 percent of the area is covered by Pleistocene glacial deposits, except in the southeastern part of the study area (southcentral Ohio) (fig. 11). The deposits generally consist of end moraine and ground moraines (till), outwash sediments, and lacustrine deposits, and represent three major stages of Wisconsinan age glaciation: Early, Middle, and Late Wisconsinan. Advances by the Late Wisconsinan Laurentide ice sheet removed surficial evidence of earlier glaciations in most places except south of the Wisconsinan glacial limit (fig. 11) (Fullerton, 1986). The resulting landscape and internal structure of the glacial deposits is a mixture of unconsolidated deposits from multiple glacial advances and retreats.

The direction of ice flow, determined from erosional and depositional features, indicates that ice advances during the Late Wisconsinan time crossed the Lake Erie Basin and the interstadial lakes accounting for much of the clay component in the tills (Flint, 1971 and Whillans, 1985). Because much of the ice overrode the Lake Erie Basin, the mineral composition of tills within the study area mostly is representative of the local bedrock underlying the basin (Strobel and Faure, 1987); generally being clay-rich because of the types of rocks (limestone, dolomite, and shale) and their low resistance to glacial erosion.

The thickness of glacial deposits varies throughout the Midwestern Basins and Aches region, ranging from $0 \mathrm{ft}$ where the deposits are absent in parts of southwest Ohio and southeast Indiana to more than $400 \mathrm{ft}$ in outwash areas in west-central and northwest Indiana and within the buried Teays-Mahomet valleys (fig. 12) (Soller, 1986 and Bleuer, 1991). A prominent area of thin deposits, generally less than $50 \mathrm{ft}$ thick, which is coincident with the Glacial Lake Maumee plain, is present in the northeastern part of the study area (fig. 12).

A system of pre-Pleistocene, buried-river valleys extends throughout the study area. The most prominent of these is the Teays-Mahomet system (Goldthwait, 1991; Bleuer, 1991; Gray, 1991)(fig. 11). These buried valleys are filled with deposits ranging from lacustrine clays to sands and gravels depending on their location and local depositional history. Generally, though, the main stem of the Teays-Mahomet buried valley is filled with finer-grained deposits from southcentral Ohio to near the Ohio-Indiana border, where the fill generally changes to coarser sand and gravel-type deposits (Bingham and others, 1991; Bleuer, 1991).

\section{HYDROGEOLOGIC UNITS}

\section{SURFICIAL AQUIFER}

The surficial aquifer-typically glacial outwash or thin, discontinuous lenses of permeable material within till-is generally composed of sands and gravels. The surficial aquifer also includes alluvium of Holocene age that lies along streams and their flood plains. The deposits are mostly unconfined (for example, where outwash sediments are present along the major rivers in the study area) but locally may be semiconfined or confined by layers of till. Transmissivities of these deposits generally range from 300 to $69,700 \mathrm{ft}^{2} / \mathrm{d}$ (Joseph and Eberts, 1994). In some parts of the study area, especially in northwestern and central-western Ohio, the vertical flow of water is greater than would be expected because the fractures in the tills allows flow to depths as great as $30 \mathrm{ft}$ (Strobel, 1993). In these areas the vertical hydraulic conductivity can be more than $1 \mathrm{ft} / \mathrm{d}$ (Strobel, 1993); however, average vertical hydraulic conductivities gen- 


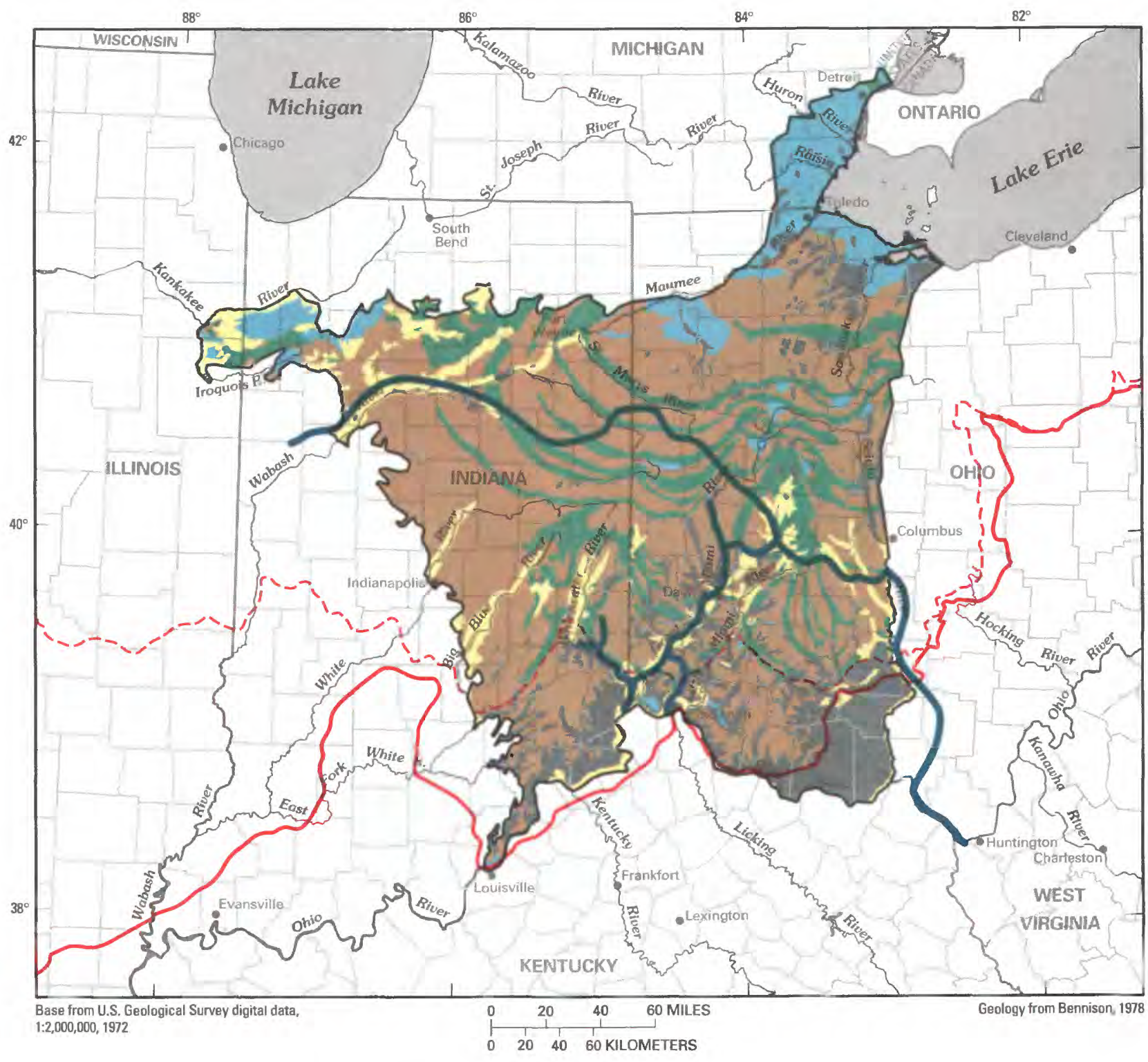

EXPLANATION

Glacial deposits
Ground moraine
End moraine
Lacustrine deposits
Outwash deposits
Undifferentiated glacial deposits
(thin or absent)

Buried Teays-Mahomet valley system-Main stem and principal tributaries

Southern extent of glaciation

- - - Southern extent of Wisconsin glaciation

Boundary of study area

FIGURE 11. - Glacial deposits, extent of glaciation, and approximate location of the main stem and principal tributaries of the buried Teays-Mahomet valley system in the Midwestern Basins and Arches Region.

erally range from 0.0001 to $0.77 \mathrm{ft} / \mathrm{d}$ in till (Joseph and Eberts, 1994).

In areas where ground water is unconfined, the water table generally is within the surficial aquifer and the water-table configuration closely mimics topogra- phy throughout the study area. The depth to the water table generally increases in topographically high areas and decreases in regionally low areas, such as stream valleys and near Lake Erie. A detailed discussion of the relation between land-surface altitude and water-table 


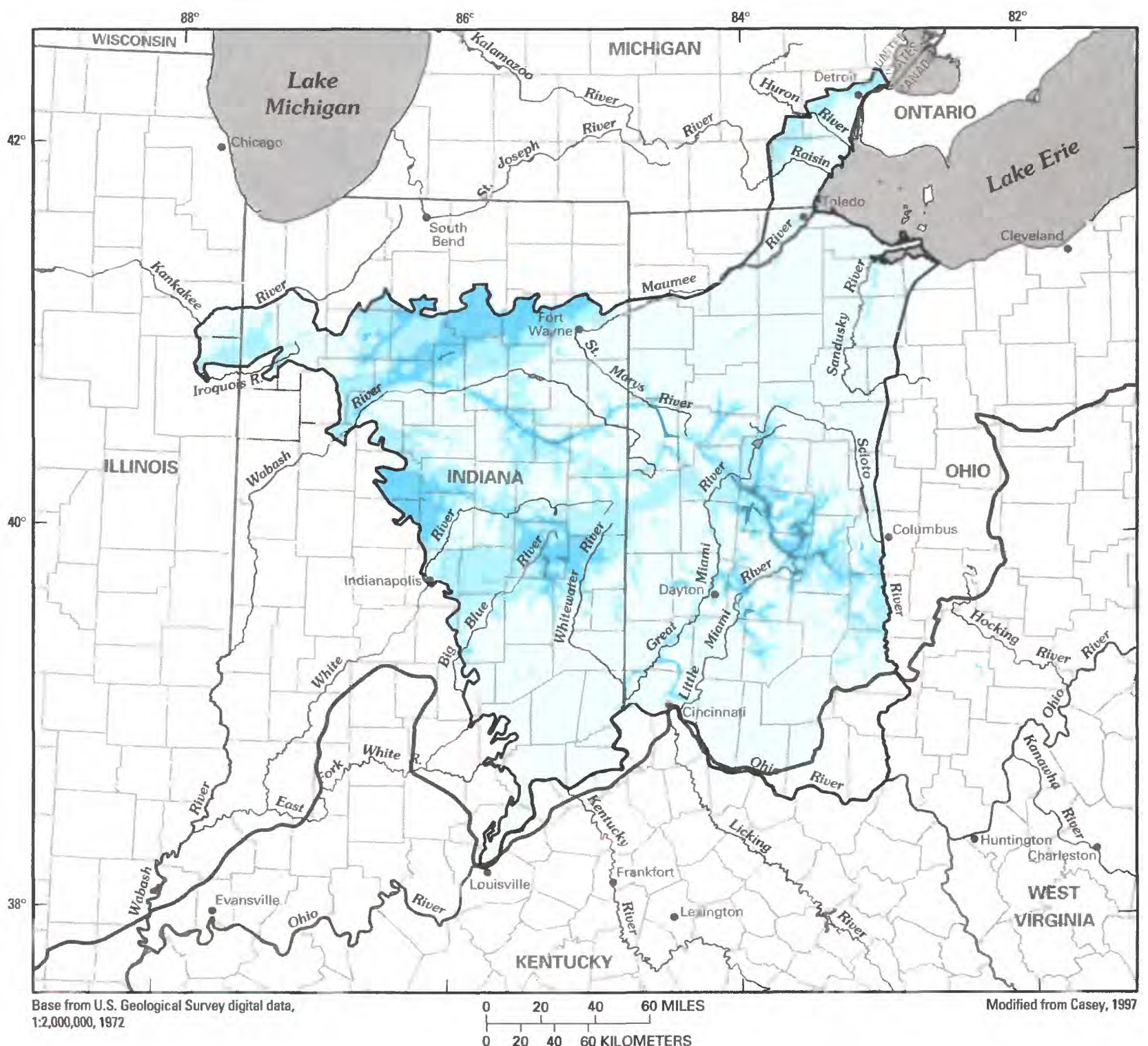

EXPLANATION

Thickness of glacial deposits

Less than 100 feet

100 to 200 feet

201 to 400 feet

Greater than 400 feet

- Southern extent of glaciation

Boundary of study area

FIGURE 12.-Generalized thickness of glacial deposits in the Midwestern Basins and Arches Region 
altitude in the surficial aquifer (with reference to longterm steady-state conditions) can be found in Eberts (in press). Most fluctuations of the ground-water levels within these deposits are seasonal and generally are less than $10 \mathrm{ft}$ (Clark, 1980; Shindel and others, 1991a, 1991b).

The potential yield of wells producing water from the surficial aquifer varies over small distances because of differences in the composition, continuity, and structure of the deposits (Strobel, 1993). Specific capacity of wells tapping the surficial aquifer within the study area ranges from 0.01 to $420 \mathrm{gal} / \mathrm{min} / \mathrm{ft}$. Yields of wells generally range from 0.5 to $7,700 \mathrm{gal} / \mathrm{min}$.

\section{CARBONATE-ROCKAQUIFER}

The carbonate-rock aquifer is composed primarily of limestone and dolomite of Middle Devonian to Alexandrian age; thin shale units are present in places (fig. 7). Most of the regional carbonate-rock aquifer is semiconfined by the surficial aquifer-mostly by till-within the study area, primarily along the structural arches; a small part of the carbonate-rock aquifer is confined outside of the study area by Upper Devonian and Lower Mississippian shale (figs. 5, 6 and 7). The carbonaterock aquifer is confined below by shale and shaley limestone of Cincinnatian age (fig. 7).

Water in the underlying carbonate-rock aquifer occurs primarily in fractures, bedding joints, and other openings as secondary permeability within the rock. Arihood (1994) reported that most of the active flow within fractures is within the upper $50 \mathrm{ft}$ in three wells tested in northwest Indiana. Similarly, data from the USGS's Ground Water Site Inventory (GWSI) data base indicates that 86 percent of more than 1,100 wells within the study area in the carbonate-rock aquifer were drilled to less than $100 \mathrm{ft}$ into bedrock; thus most of the secondary permeability is within at least the upper 100 $\mathrm{ft}$ of the carbonate-rock aquifer. The carbonate-rock aquifer ranges in thickness from $0 \mathrm{ft}$ to more than 2,300 $\mathrm{ft}$ within the study area, and it thickens from the crest of the arches into the adjacent structural basins within the region (Norris and Fidler, 1973; Rupp, 1991; Casey, 1997) (fig 8).

The limit of freshwater within the carbonate aquifer, considered for this study to be less than $10,000 \mathrm{mg} / \mathrm{L}$ dissolved solids (U.S. Environmental Protection Agency, 1984), has been found in carbonate bedrock of Silurian and Devonian age as far as $70 \mathrm{mi}$ west of the study area within the Illinois Basin (Rupp and Pennington, 1987; D. Schnoebelen, U.S. Geological survey, written commun., 1992). The limits of freshwater also occur within areas $5 \mathrm{mi}$ north of the northern limit of the study area in the Michigan Basin (D. J. Schnoebelen, written commun., 1992) and within several miles of the eastern boundary of the study area on the margin of the Appalachian Basin (fig. 9).

Some units, or zones, within the carbonate-rock aquifer are more productive than others. The Newburg Zone (Strobel and Bugliosi, 1991) is one such example. Most of the carbonate-rock aquifer, however, functions as a single hydrologic unit at the scale of the Midwestern Basins and Arches Region. In a regional discharge area in northwestern Indiana, for example, vertical hydraulic gradients were less than $3 \mathrm{ft}$ in three, $600-\mathrm{ft}$ deep wells that penetrate the entire thickness of the carbonate-rock aquifer (Arihood, 1994).

Few wells tap the carbonate-rock aquifer where it dips beneath the Devonian shales because shallower freshwater sources are available. Within the study area, the potential yield from wells drilled into the carbonaterock aquifer differs areally and is related to the degree of secondary permeability. The specific capacity of wells within the carbonate-rock aquifer ranges from 0.1 to 90 $\mathrm{gal} / \mathrm{min} / \mathrm{ft}$; yields range from 0 to about $1,000 \mathrm{gal} /$ min.

\section{REGIONAL GROUND-WATER FLOW}

Ground-water flow in the Midwestern Basins and Arches Region is affected by topography and by the hydraulic characteristics of the surficial and carbonaterock aquifers and confining units that compose the regional aquifer system. Water flows from areas of recharge to areas of discharge, but at local, intermediate, and regional scales (Toth,1963) (fig. 13). This study focused primarily on ground water that flows at least several miles before discharging to streams, lakes, or wells that are drilled into the surficial deposits and, especially, the carbonate-rock aquifer. The limited focus was a consequence necessitated by the large area of study and the subsequent coarse discretization ( 4 by 4 mi) of the numerical model used for analysis of the regional ground-water-flow system. Local flow to small perennial streams could not be simulated because of the coarse discretization necessary for the model.

Throughout most of the study area, the carbonaterock aquifer is considered to be in a state of quasi-equilibrium (steady-state condition). No component of storage at a regional scale was considered. However, in northwestern Indiana - an area of intensive agricultural development-intensive pumping from the carbonaterock aquifer during periods of irrigation has stressed the ground-water system. Seasonal, subregional transient conditions in which the potentiometric surface in the carbonate-rock aquifer declines below the top of the aquifer, creates locally unconfined conditions and 

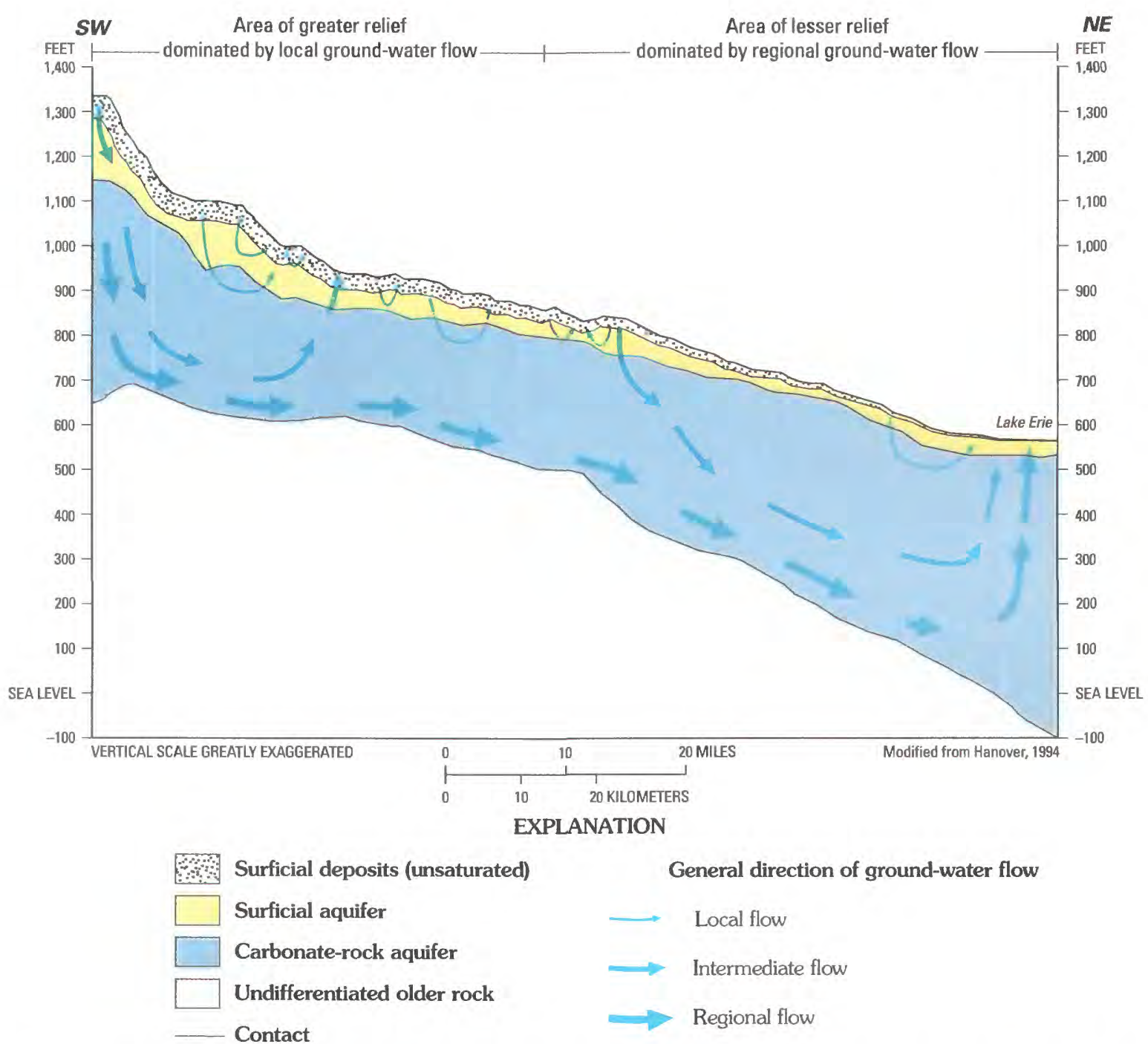

General direction of ground-water flow

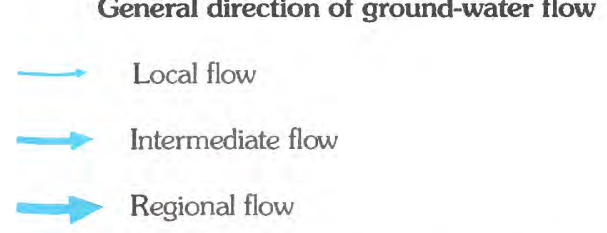

FIGURE 13,-Conceptual hydrogeologic section showing the relation between local, intermediate, and regional flow in the Midwestern Basins and Arches Region (trace of section shown in figure 17).

ground water is pumped from storage in the aquifer (Arihood, 1994). Because the transient conditions occur in only a small part of the regional aquifer system and are seasonal, no additional investigations of transient conditions in this area of the carbonate-rock aquifer were made.

\section{HYDROGEOLOGIC BOUNDARIES}

The boundaries of regional ground-water flow in the Midwestern Basin and Arches Region are defined physically by the hydrogeologic framework and geochemically by the $10,000-\mathrm{mg} / \mathrm{L}$ dissolved solids limit within the carbonate-rock aquifer (fig. 9). The 10,000-mg/L dissolved solids limit was selected to represent the lateral extent of the regional ground-water-flow system because (1) $10,000 \mathrm{mg} / \mathrm{L}$ is the minimum recommended secondary standard for consumptive use (U. S. Environmental Protection Agency, 1984), (2) the multiple-density ground-water-flow simulations necessary for waters with dissolved-solids concentrations greater than $10,000 \mathrm{mg} / \mathrm{L}$ were beyond the scope of this study, and (3) hydrogeologic information available for the area beyond this boundary is sparse. The carbonaterock aquifer is confined above by either the surficial deposits throughout most of the study area or by shales of Devonian and Mississippian age on the flanks of the structural arches, where the rock units of Silurian and Devonian age dip into the structural basins. The aquifer is confined below by shales and shaley limestones of Ordovician age. The water table is the uppermost boundary of regional ground-water flow.

Discharge boundaries for regional ground-water flow include Lake Erie and most of the major streams 
within the area. The Kankakee and Iroquois Rivers in northwestern Indiana and east-central Illinois function as a regional ground-water discharge area that separates the flow system in the carbonate-rock aquifer in northwest Indiana from a regional flow system further northward in Illinois and Wisconsin (figs. 5, 6, and 10) (Young, 1992; Mandle and Kontis, 1992). The Scioto River is a major discharge boundary for the carbonaterock aquifer along much of the eastern part of the study area in central Ohio. Additionally, former swamps, such as those in northwestern Ohio that are extensively drained by tile and ditches, function as regional discharge areas (Kaatz, 1952). The Ohio River is a major hydrologic boundary within the area, but only a small portion of the carbonate-rock aquifer extends to this boundary (fig. 5).

Internal boundaries include the ancestral TeaysMahomet River system where it is filled with glacial deposits of varied permeabilities that contrast with the permeability of the surrounding carbonate-rock aquifer, especially where the valleys incise the entire carbonaterock aquifer (figs. 5, 6, and 10); however, these valleys function primarily as local discharge boundaries throughout most of the region (Sheets and Yost, 1994), especially where they are filled with highly permeable sand and gravel; as in the central and western part of the study area (Bleuer, 1991) (fig. 11). In contrast, part of the buried Teays Valley in southwestern Ohio is filled with fine-grained deposits and it is relatively impermeable (Sheets and Yost, 1994). These valleys appear to have no effect on the direction of ground-water flow at a regional scale, (Eberts, in press) and they were not considered explicitly as internal boundaries in the regional ground-water-flow model constructed for this study.

\section{POTENTIOMETRIC SURFACES}

Ground-water levels within the Midwestern Basins and Arches Region, not only in the surficial aquifer, but also in the carbonate-rock aquifer generally mimic the topography of the area. Where ground water is unconfined, the water table is within the surficial aquifer except in areas where the surficial deposits are thin or absent, in which case the water table is within the carbonate-rock aquifer. Depth to water generally increases with increasing land-surface altitude (as, for example, near the highest point in the study area in central-western Ohio) and decreases with decreasing altitudes (as, for example, near Lake Erie or the Ohio or Kankakee Rivers) (Hanover, 1994; Eberts, in press).

A regional water-level map (fig. 14) representing the aggregate water levels from wells drilled in surficial deposits in the Midwestern Basins and Arches Region shows the same general configuration as the topography (fig. 2). Configuration of the potentiometric surface of the carbonate-rock aquifer (fig. 15) is similar to that of the water-level surface in the surficial aquifer. Two predominant potentiometric high areas in the carbonaterock aquifer are in central-western Ohio and near the southern limit of the aquifer along the border between Indiana and Ohio (fig. 15). Potentiometric low areas, 600 $\mathrm{ft}$ or less, are along the major regional drains to the aquifer system (the Wabash and the Ohio Rivers and Lake Erie). Potentiometric contours within the region characteristically wrap around the major rivers, pointing upstream, indicating that ground-water discharges to most of the major rivers. The potentiometric surface flattens around the area of the Maumee River Basin, in the north-central and northeastern part of the study area (fig. 4).

\section{RECHARGE AND DISCHARGE}

The mean regional ground-water discharge for a long-term period (tens of years) approximates the mean recharge to the regional ground-water-flow systems within the Midwestern Basins and Arches Region because the regional aquifer system is in steady state (equilibrium) over these long periods. All recharge to the regional ground-water-flow system is from precipitation either directly on the surficial deposits throughout most of the study area or directly on the carbonate bedrock where it is exposed at, or within a few feet of, the surface. Few regional estimates of recharge have been made; however, a few local estimates have been reported in the literature: (1) recharge to the surficial aquifer, estimated as recharge through unsaturated glacial till at 1.4 and $1.8 \mathrm{in} / \mathrm{yr}$ (Daniels and others 1991), (2) 12 and 12.4-15.8 in/yr through outwash deposits (Walton and Scudder, 1960; Dumouchelle and others,1993) respectively, and (3) 8 and $2 \mathrm{in} / \mathrm{yr}$ through till on uplands in the Great Miami River Basin (Walton and Scudder, 1960; Dumouchelle and others,1993). Recharge to the carbonate-rock aquifer has been estimated to range from 0.14 to $6.3 \mathrm{in} / \mathrm{yr}$ (Watkins and Rosenshein, 1963; Rowland and Kunkle, 1970; Cravens and others, 1990; Roadcap and others, 1993).

Regional ground-water discharge from the Midwestern Basins and Arches aquifer system is mainly to the major rivers and lakes within the area; a lesser amount of discharge is by evapotranspiration. Ground-water discharge to the unregulated reaches of large streams within the study area was estimated from streamflow data by separating out daily mean base flow to these streams from streamflow hydrographs (Eberts, in press) 


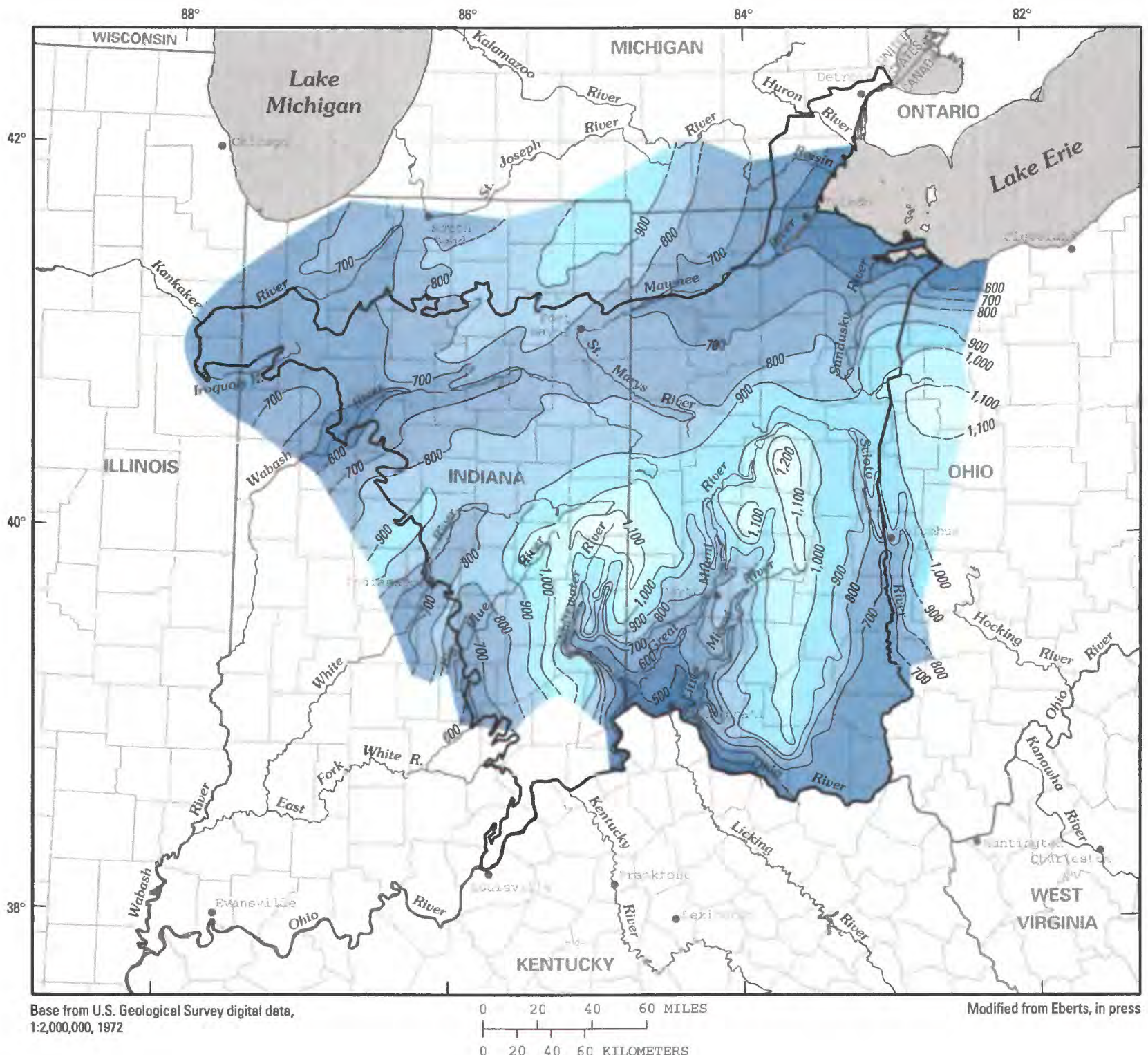

\section{EXPLANATION}

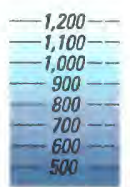

Altitude of composite water level in surficial

deposits-Contour interval 100 feet.

Dashed where inferred. Datum is sea level.

Darker blues indicate lower altitude

\section{Boundary of study area}

FIGURE 14.-Generalized ground-water level configuration for the surficial aquifer in the Midwestern Basins and Arches Region.

by use of the local-minimum method of Pettyjohn and Henning (1979). The mean ground-water discharge to stream reaches above the selected streamflow-gaging stations was then estimated from the daily mean baseflow data (Eberts, in press). This mean ground-water discharge to streams describes long-term (tens of years), steady-state conditions within the Midwestern Basins and Arches aquifer system. The mean ground-water discharge for the selected reaches of streams ranged from 17 to 80 percent of total mean streamflow (Eberts, in press).

Base-flow-duration curves (the frequency that a particular base flow is met or exceeded in a given period) were constructed from daily mean base-flow data and 

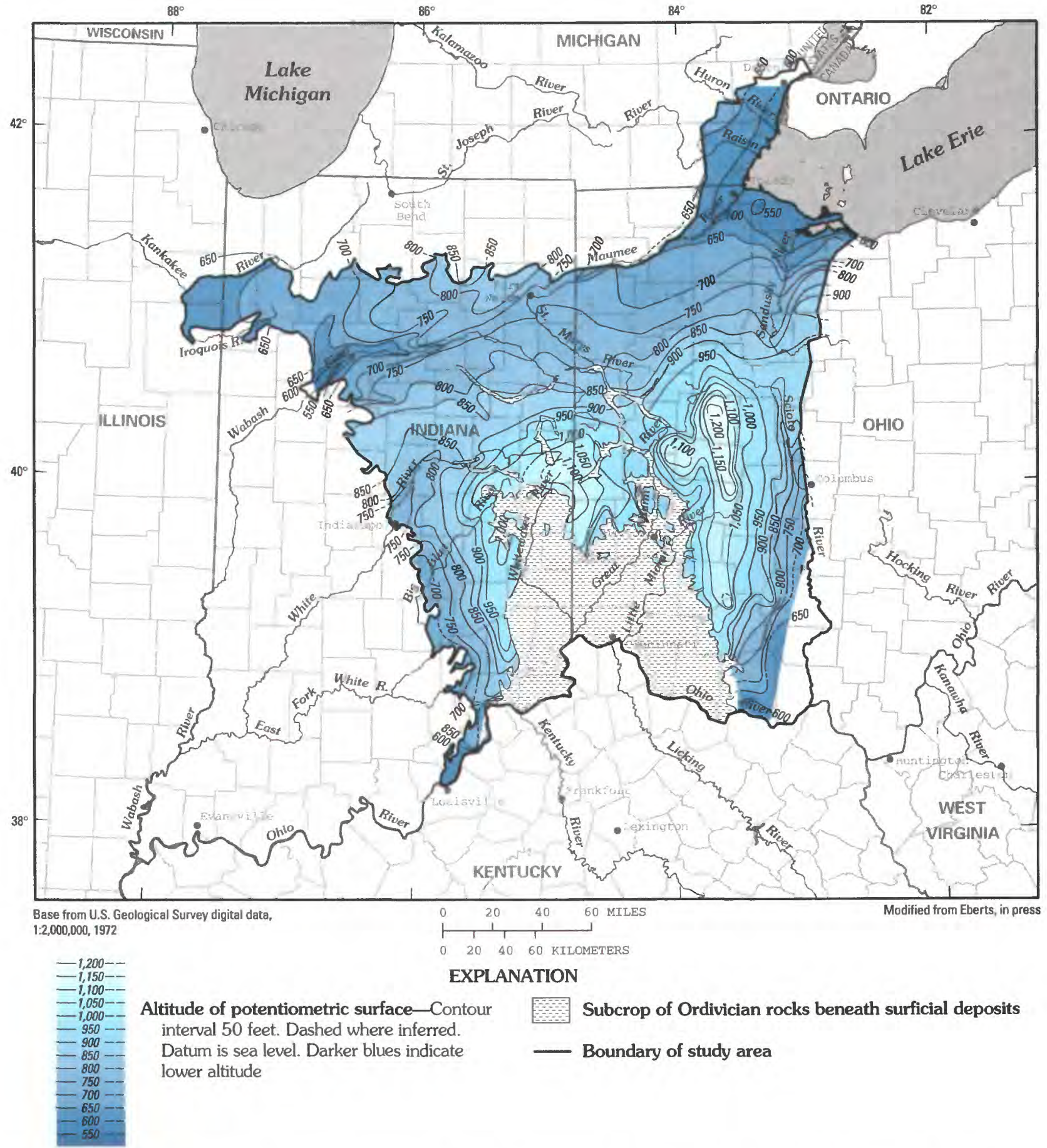

EXPLANATION

Altitude of potentiometric surface-Contour interval 50 feet. Dashed where inferred. Datum is sea level. Darker blues indicate lower altitude
Subcrop of Ordivician rocks beneath surficial deposits

Boundary of study area

FIGURE 15.-Potentiometric-surface configuration for the carbonate-rock aquifer in the Midwestern Basins and Arches Region.

used to estimate the regional, sustained component of ground-water discharge to a stream, and is referred to herein as "sustained base flow" or "sustained groundwater discharge" (Eberts, in press). The mean sustained ground-water discharge to stream reaches between streamflow-gaging stations was estimated by comput- ing the difference between estimates of mean sustained ground-water discharge at adjacent gaging stations (fig. 16). These mean sustained ground-water discharges ranged from 3 to 50 percent of the mean ground-water discharge (fig. 16) (Eberts, in press). 


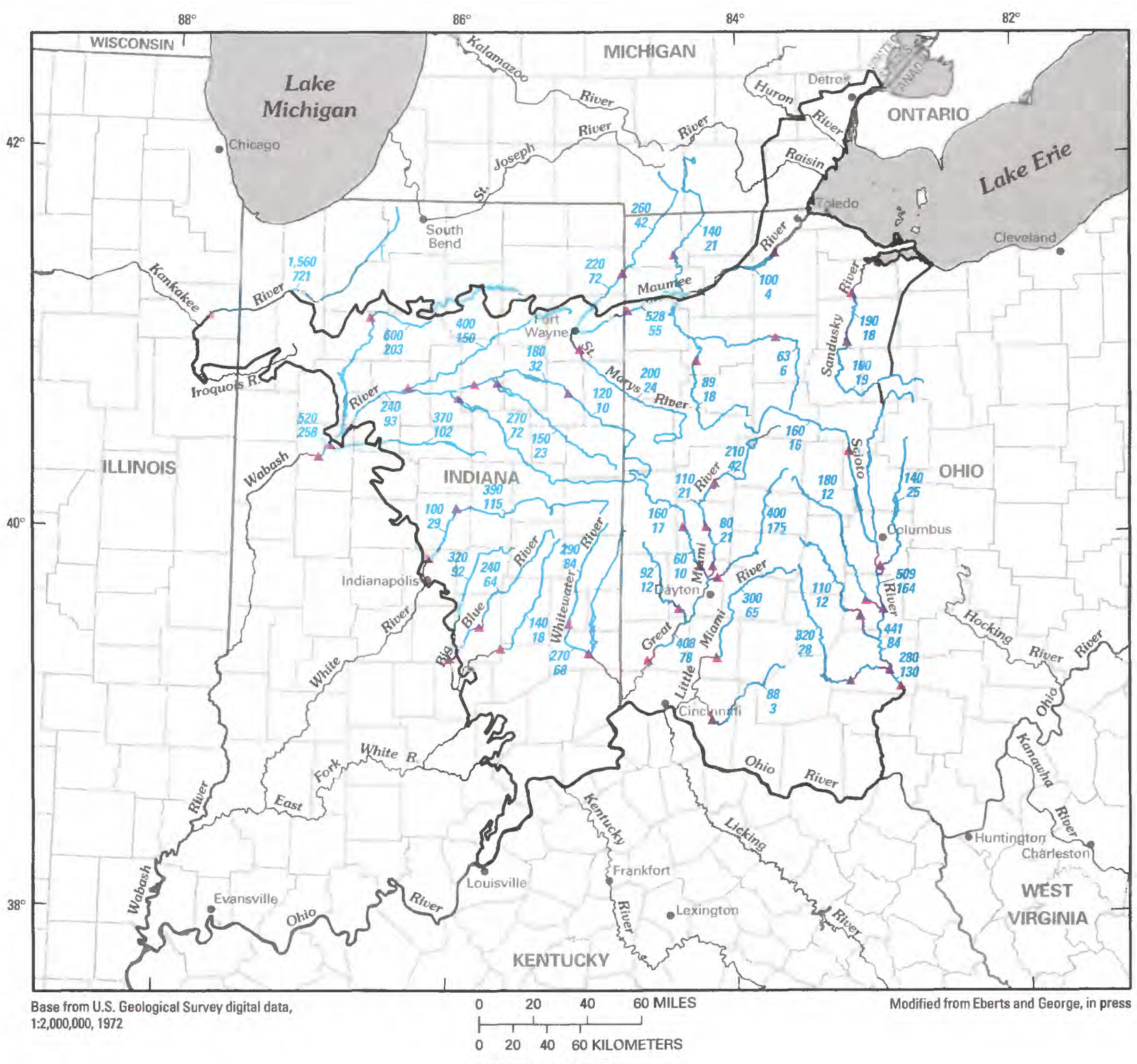

EXPLANATION

140 Base flow to stream reach-Numbers are estimates in cubic feet per second. Upper number is mean ground-water discharge calculated from hydrograph separation. Lower number is mean sustained ground-water discharge

Stream reach used in base-flow analysis

\section{Boundary of study area}

\section{A Continuous-record streamflow-gaging station}

FIGURE 16-Calculated mean and mean sustained ground-water discharge to selected reaches along major streams in the Midwestern Basins and Arches Region. 


\section{GROUND-WATER-FLOW SIMULATIONS}

The focus of this study - the regional ground-waterflow components of the surficial and carbonate-rock aquifers within the Midwestern Basins and Arches Region-pertained to the ground water that enters the study area and flows tens of miles before discharging to streams or remaining in the subsurface and flowing beyond the 10,000-mg/L dissolved-solids boundary. The objectives of this study (Bugliosi, 1990), the practicality of collecting and analyzing data for such a large area, and the resulting coarseness of the regional-flowmodel grid limited this study to a description of regional ground-water flow. Consequently, the groundwater-flow simulations were not designed to address shallow, local components of ground-water-flow paths less than $4 \mathrm{mi}$. long

One regional and two subregional ground-waterflow simulations were evaluated to test the conceptual model of the regional aquifer system; specifically, to test the conceptualization of external and internal boundaries of ground-water flow (fig. 17). The regional ground-water-flow model was constructed to (1) test and improve upon the conceptual model of regional flow, (2) compute a regional ground-water budget, (3) determine recharge and discharge areas, and (4) identify ground-water-flow patterns within the study area. Additionally, a two-dimensional, steady-state, crosssectional-flow model was constructed to determine ground-water pathlines and traveltimes along a flow path from a regional recharge area (a potentiometric and topographically high area in central-western Ohio) to a regional discharge area (Lake Erie) and to test the conceptual model of regional flow along a single flow path. A subregional, transient ground-water-flow model was previously developed by Arihood (1994) for a predominantly agricultural area in northwestern Indiana. This heavily irrigated area exhibits seasonal changes in ground-water storage in the carbonate-rock aquifer, and is the only known part of the Midwestern Basins and Arches Region where transient groundwater conditions occur. The subregional ground-waterflow models had finer grid spacings than the regional model ( $4 \mathrm{mi} \mathrm{X} 4 \mathrm{mi}$ ) and thus represented the flow system in these areas in greater detail.

\section{REGIONAL SIMULATION}

The regional ground-water-flow model was designed to simulate steady-state, regional flow conditions within the Midwestern Basins and Arches aquifer system without explicitly representing local flow systems that are too small and numerous to be adequately simulated with a regional-scale model (Eberts and
George, in press). Ground-water withdrawals were not simulated because the regional aquifer is not stressed enough to produce widespread transient conditions.

Surficial deposits were simulated as layer 1 in the model. Rocks of Ordovician age were simulated as part of model layer 2 where the carbonate-rock aquifer is absent and these Ordovician rocks subcrop beneath thin, surficial deposits in the south-central part of the study area. The shale subregional confining unit was not represented as a separate model layer but rather as a resistance to vertical flow between layer 1 and layer 2 . Each model cell was $16 \mathrm{mi}^{2}$ (4 X $4 \mathrm{mi}$ ) and parameter values, such as hydraulic conductivity, were assumed to be constant within individual model cells. The model grid was oriented parallel to the contact between carbonate and shale rocks of Devonian age along the margin of the Illinois Basin because no physical hydrologic boundary is present in this area (fig. 18). Boundaries for the regional flow model were set according to table 1 and are shown in figure 18. A detailed description of these boundaries is given in (Eberts and George, in press).

Parameter-estimation and testing codes (Hill, 1992, 1994) were used to estimate parameter values by nonlinear regression and to test the confidence of the hydrologic parameters used in the calibrated regional ground-water-flow model, namely (1) horizontal hydraulic conductivity or transmissivity, (2) vertical hydraulic conductivity, (3) streambed hydraulic conductivity, (4) a conductance term for the general headdependent-flux boundary condition that was used to simulate ground-water flux at the regional water-table interface, and (5) effective recharge to the regional ground-water-flow system (Eberts and George, in press). The relative sensitivity of model output to changes in these hydrologic parameters used to calibrate the ground-water-flow model and final calibrated parameter values are given in table 2 .

A comparison of simulated and measured hydraulic heads (fig. 19) and comparison of calculated and simulated regional ground-water discharge to major streams (fig. 20) indicates that model calibration was achieved (Eberts and George, in press).

A regional ground-water-flow budget was estimated by use of output from the calibrated ground-water-flow model (table 3) (Eberts and George, in press). This budget does not account for localized ground-water flow, which is an important part of the overall ground-waterflow budget within the regional aquifer system.

A map of regional ground-water recharge and discharge areas (fig. 21) based on output from the calibrated ground-water-flow model (Eberts and George, in press) shows a pattern of alternating recharge and discharge areas, except in and around the Maumee and 


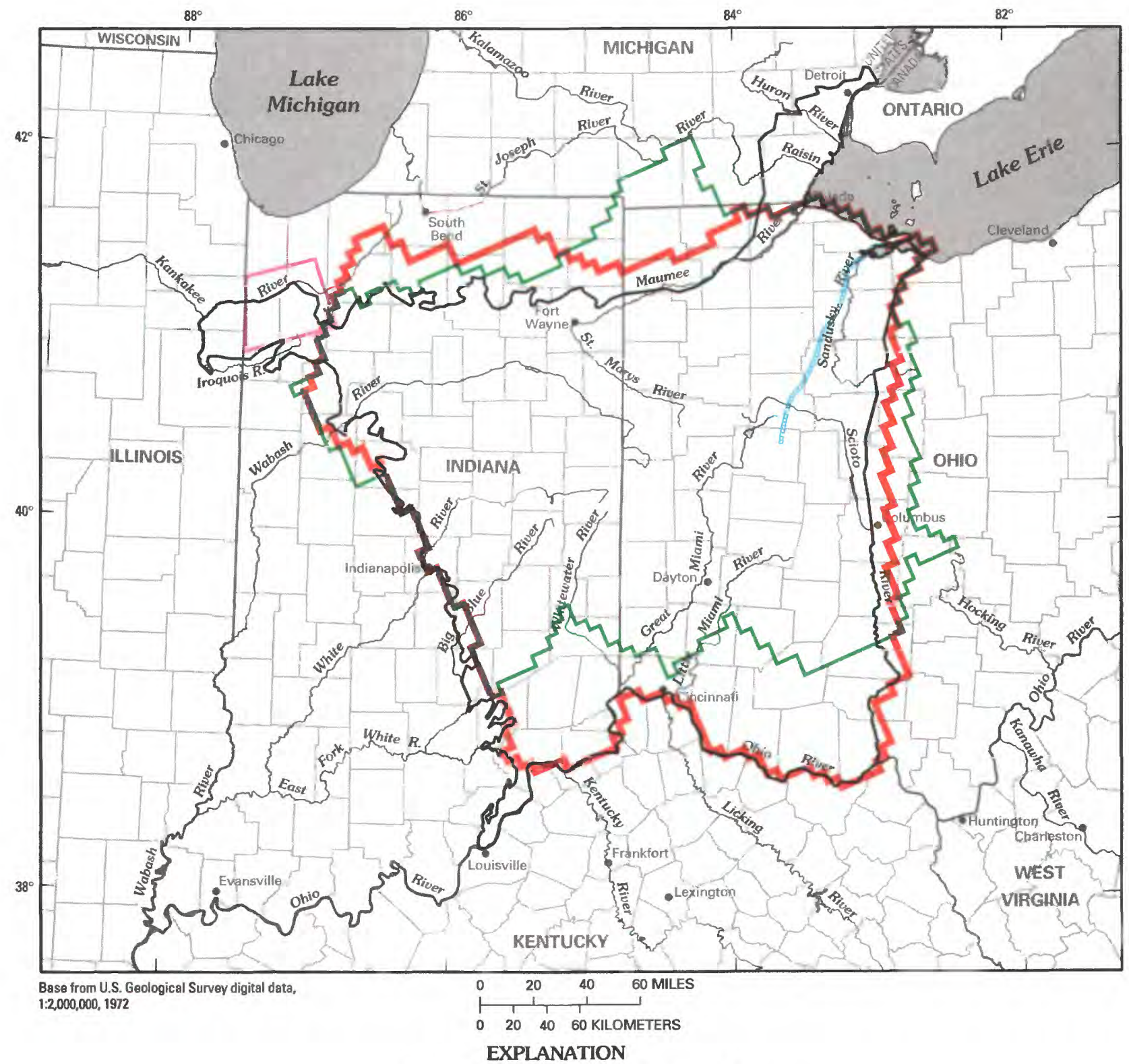

Boundaries of ground-water-flow models

Regional ground-water-flow model

Layer 1 (surficial aquifer)
Layer 2 (carbonate-rock aquifer)

Subregional ground-water-flow models

Cross-sectional model (Hanover, 1994). (See figure 13 for details)

Transient model (Arihood, 1994a)

Boundary of study area

FigURE 17.-Model areas for regional and subregional ground-water-flow models in the Midwestern Basins and Arches Region. 

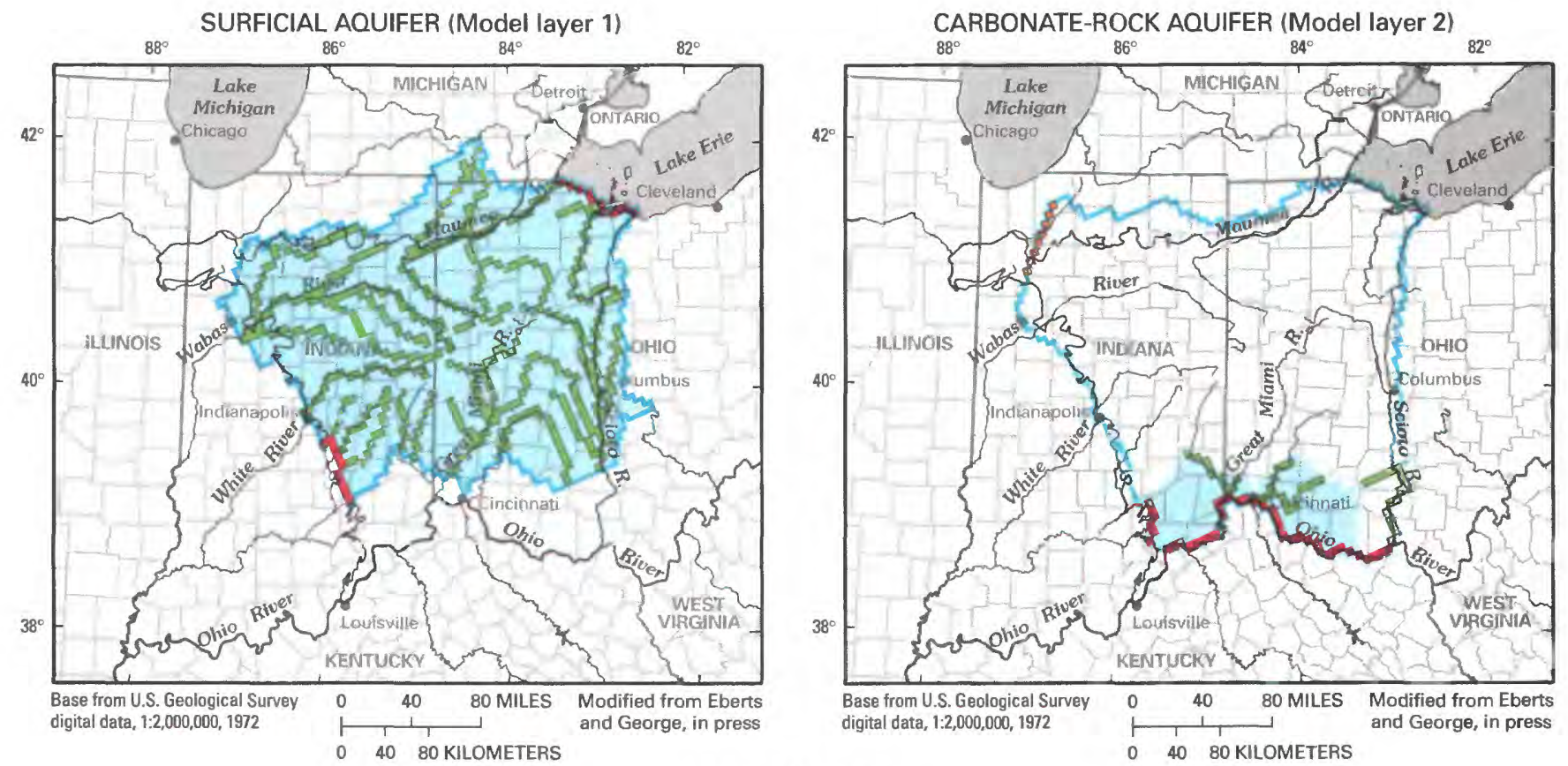

\section{EXPLANATION}

Model boundaries

General head-dependent flux

Specified head

Head-dependent flux

Specified flux (carbonate-rock aquifer only)

- No flow

_ Boundary of study area

FIGURE 18.-Boundary conditions used in the regional ground-water-flow model of the surficial and carbonate-rock aquifers in the Midwestern Basins and Arches Region.

Sandusky River Basins, where discharge areas dominate. The map (fig. 21) indicates that few regional ground-water-flow paths extend from high to low regional potentiometric areas over distances greater than a few tens of miles; instead, flow is dominated by shorter flow paths (fig. 22). The dominant trend of shorter ground-water-flow paths within the Midwestern Basins and Arches Region is substantiated by variable-density-modeling results of Gupta (1993), indicating that a small volume of ground water, in a region that extends further than the boundaries of the Midwestern Basins and Arches Region (this study), passes through the rocks of Ordovician age (bottom of the conceptual model for this study) and flows into the surrounding structural basins. It is these very long (hundreds of miles) flow paths that are truly "regional." However, these very longe flow paths were not consid- ered for this study because they represent a volume of ground-water flow that is significantly less than the total ground-water flow accounted for in the model constructed for this study.

The primary factors controlling the ground-waterflow patterns in the Midwestern Basins and Arches Region are the relatively subdued topography and the low ratio of depth to lateral extent of the regional aquifer system. The water-table configuration is closely associated with the topographic relief in the area, as is the potentiometric surface of the carbonate-rock aquifer (Eberts and George, in press). Because the range in altitude in the study area is less than 1,000 ft and only two small topographically high areas are present (fig. 2), short flow paths (a few miles) are dominant throughout the region. The low ratio of depth to lateral extent of the regional aquifer system also produces shorter ground- 
TABLE 1.-Regional ground-water-flow model boundaries and the areas to which each boundary is applied [Modified from Eberts and George, in press. Boundaries are shown in figure 18]

\begin{tabular}{|c|c|c|c|}
\hline & Surficial aquifer (layer 1 ) & \multicolumn{2}{|c|}{ Carbonate-rock aquifer (layer 2) } \\
\hline \multicolumn{4}{|l|}{$\begin{array}{l}\text { No-flow } \\
\text { (includes streamlines, surface-water } \\
\text { drainage divides, limit of Wisconsinian } \\
\text { glaciation, ground-water divides, top of } \\
\text { Ordovician rocks, Lake Erie shoreline, } \\
\text { and the } 10,000 \mathrm{mg} / \mathrm{L} \text { dissolved-solids- } \\
\text { concentration boundary). }\end{array}$} \\
\hline $\begin{array}{l}\text { Specified head } \\
\text { (includes Lake Erie shoreline, } 700 \text { foot } \\
\text { ground-water equipotential, and the } \\
\text { Ohio River). }\end{array}$ & $\begin{array}{l}\text { Lake Erie shoreline and southern- } \\
\text { most part of western boundary. }\end{array}$ & \multicolumn{2}{|c|}{$\begin{array}{l}\text { Ohio River along southern part of study } \\
\text { area and southernmost part of western } \\
\text { boundary where surficial deposits are } \\
\text { absent or very thin. }\end{array}$} \\
\hline $\begin{array}{l}\text { Specified flux } \\
\text { (includes flow into Illinois Basin). }\end{array}$ & None. & \multicolumn{2}{|c|}{$\begin{array}{l}\text { Northernmost part of study area where } \\
\text { flow is into Illinois Basin. }\end{array}$} \\
\hline $\begin{array}{l}\text { Head-dependent flux } \\
\text { (includes most large streams in study area). }\end{array}$ & Principal streams. & \multicolumn{2}{|c|}{$\begin{array}{l}\text { Principal streams (only in areas where } \\
\text { layer } 1 \text { is absent in the model). }\end{array}$} \\
\hline $\begin{array}{l}\text { General head-dependent flux } \\
\text { (includes interface between water table } \\
\text { in layer } 1 \text { and localized ground-water } \\
\text { discharge to smaller perennial streams). }\end{array}$ & Water-table boundary & \multicolumn{2}{|c|}{$\begin{array}{l}\text { Water-table boundary where layer } 1 \text { is } \\
\text { absent; also where layer } 1 \text { is absent and } \\
\text { the carbonate-rock aquifer is isolated } \\
\text { from shallow flow systems by the } \\
\text { Devonian and Mississippian upper } \\
\text { confining shale units, such as along the } \\
\text { lateral margins of the study area. }\end{array}$} \\
\hline \multicolumn{4}{|c|}{$\begin{array}{l}\text { TABLE 2.-Relative sensitivity and calibrated model-simulation values of hydrologic parameters for the regional ground-water-flow model } \\
\text { of the Midwestern Basins and Arches Region } \\
\qquad \begin{array}{l}{\left[\mathrm{ft}^{2} / \mathrm{d} \text {, feet squared per day; } \mathrm{ft} / \mathrm{d} \text {, feet per day; in/yr, inches per year. Modified from Eberts and George, in press, table } 3\right]}\end{array}\end{array}$} \\
\hline $\begin{array}{l}\text { Relative sensitivity of } \\
\text { model output to changes } \\
\text { in hydrologic parameters }\end{array}$ & Parameter & & Parameter value \\
\hline \multirow{7}{*}{ Most sensitive } & \multicolumn{2}{|c|}{ Transmissivity of the carbonate-rock aquifer } & $1,610 \mathrm{ft}^{2} / \mathrm{d}$ \\
\hline & \multicolumn{2}{|c|}{ Horizontal hydraulic conductivity of the morainal deposits } & $21.3 \mathrm{ft} / \mathrm{d}$ \\
\hline & \multicolumn{2}{|c|}{$\begin{array}{l}\text { Net recharge necessary to balance sustained ground-water discharge to the } \\
\text { principal streams associated with the regional ground-water-flow system }\end{array}$} & ${ }^{1} 2.15 \mathrm{in} / \mathrm{yr}$ \\
\hline & \multicolumn{2}{|c|}{ Effective vertical hydraulic conductivity of the combined moraine/bedrock areas } & $0.375 \times 10^{-2} \mathrm{ft} / \mathrm{d}$ \\
\hline & \multicolumn{2}{|c|}{$\begin{array}{l}\text { Conductance term for the general head-dependent flux boundary condition } \\
\text { used to simulate the regional water table }\end{array}$} & ${ }^{1} 0.259$ \\
\hline & \multicolumn{2}{|c|}{ Hydraulic conductivity of streambeds throughout most of the modeled area } & $0.0149 \mathrm{ft} / \mathrm{d}$ \\
\hline & \multicolumn{2}{|c|}{ Horizontal hydraulic conductivity of the outwash deposits } & $168 \mathrm{ft} / \mathrm{d}$ \\
\hline Least sensitive & \multicolumn{2}{|c|}{ Vertical hydraulic conductivity of the shale subregional confining unit } & $0.466 \times 10^{-3} \mathrm{ft} / \mathrm{d}$ \\
\hline
\end{tabular}

${ }^{1}$ Net recharge to regional flow system is computed by subtracting the flux associated with the head-dependent flux boundary conditions from the estimated value of the recharge parameter on a cell-by-cell basis. 


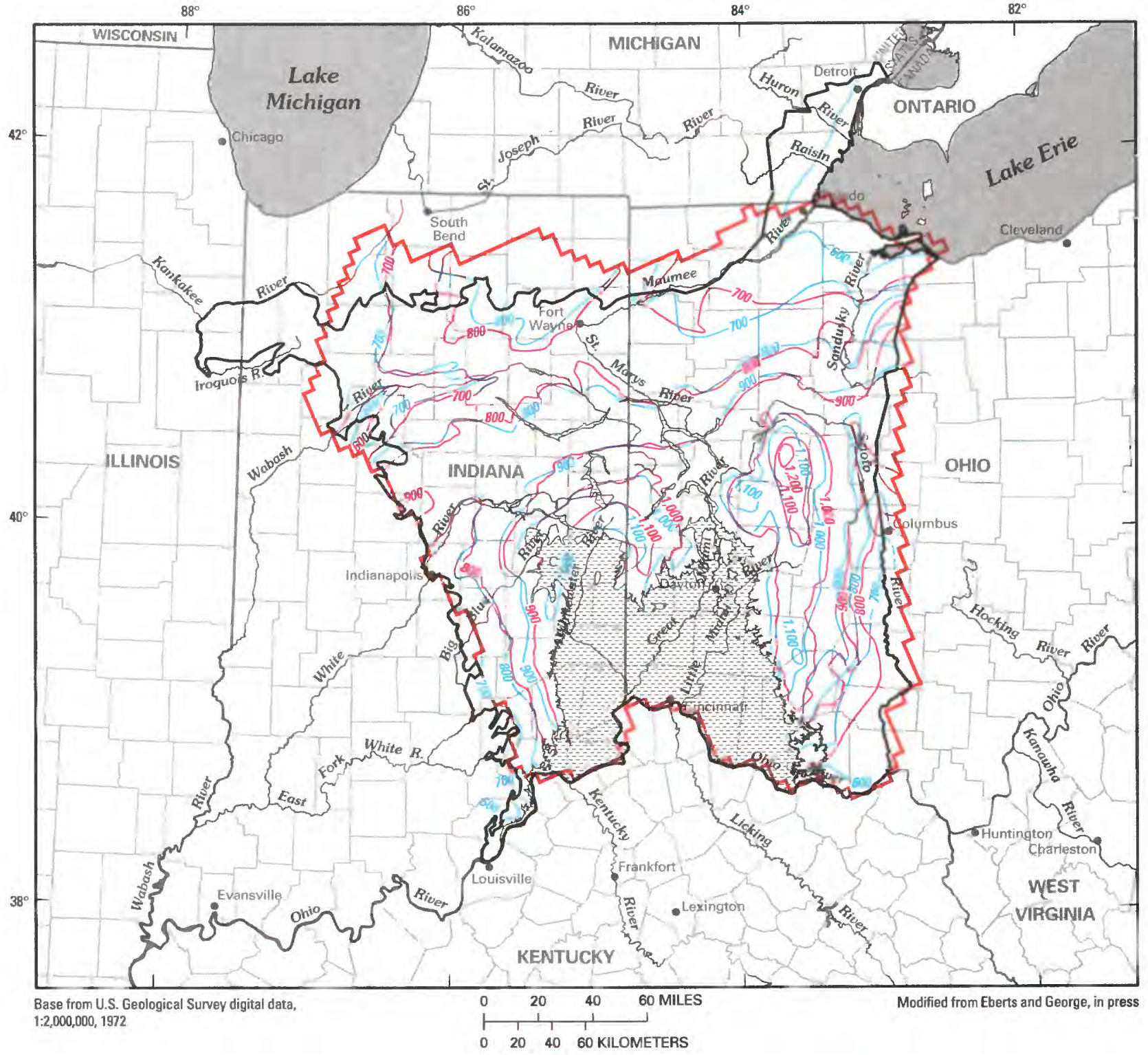

EXPLANATION

Subcrop of Ordovician rocks beneath surficial deposits

Potentiometric contour-Shows altitude at which water level would have stood in tightly cased wells, July-August 1990. Dashed where approximately located. Contour interval 100 feet. Datum is sea level

- $500--$ Potentiometic contour-Simulated by regional flow model. Contour interval 100 feet. Datum is sea level

\section{Boundary of model layer 2}

\section{Boundary of study area}

FIGURE 19.-Measured and simulated hydraulic heads for the carbonate-rock aquifer in the regional model, Midwestern Basins and Arches Region. 


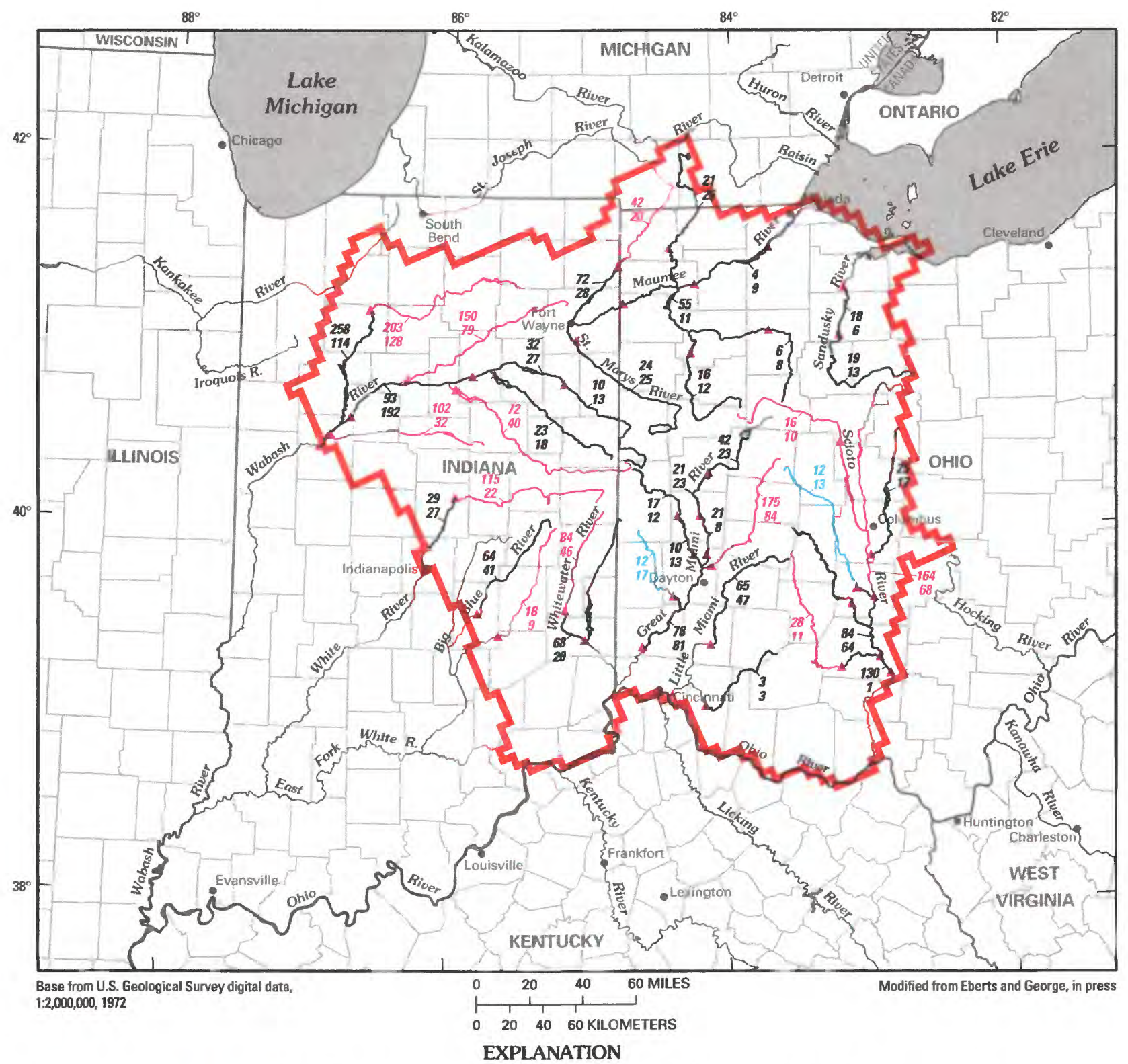

16312 Ground-water discharge to selected stream reach-Color corresponds to deviation of simulated flow from measured streamflow. Upper number is mean sustained ground-water discharge, in cubic feet per second. Lower number is simulated ground-water discharge, in cubic feet per second

Simulated ground-water discharge to streams

Under simulated-Simulated flow less than 3 times the standard deviation of the error associated with measured streamflow

- Reasonably simulated - Simulated flow within 3 times more, or less than, the standard deviation of the error associated with measured streamflow

Oversimulated-Simulated flow more than 3 times the standard deviation of the error associated with measured streamflow

\section{Boundary of modeled area}

\section{A Continuous-record streamflow-gaging station}

FIGURE 20--Measured and simulated mean sustained ground-water discharge to selected stream reaches in the Midwestern Basins and Arches Region. 
TABLE 3.-Simulated ground-water budget for regional flow in the Midwestern Basins and Arches aquifer system [Mgal/d, million gallons per day. Modified from Eberts and George, im press, table 4]

\begin{tabular}{|c|c|c|c|}
\hline Major regional ground-water-flow components & & $\begin{array}{c}\text { Flow } \\
\text { (Mgal/d) }\end{array}$ & $\begin{array}{l}\text { Percent } \\
\text { recharge or } \\
\text { discharge }\end{array}$ \\
\hline \multicolumn{4}{|l|}{ Recharge } \\
\hline Across the regional trend of the water table from precipitation & & 1,277 & 99 \\
\hline From losing stream reaches & Total & 1,292 & 100 \\
\hline \multicolumn{4}{|l|}{ Discharge } \\
\hline To principal streams & & 1,006 & 78 \\
\hline $\begin{array}{l}\text { Across the regional trend of the water table to seeps, springs, } \\
\text { small streams, or by means of evapotranspiration }\end{array}$ & & 242 & 19 \\
\hline To Lake Erie & & 1 & $<1$ \\
\hline Across the northwest boundary of the modeled area & & 1 & $<1$ \\
\hline \multirow[t]{2}{*}{ To the Ohio River from Ordovician rocks } & & $<1$ & $<1$ \\
\hline & Total & 1,292 & 100 \\
\hline
\end{tabular}

water-flow paths, as postulated by Freeze and Witherspoon, 1967). The somewhat hummocky local topography caused by glaciation theoretically contributes to the dominance of shallower flow paths (less than $100 \mathrm{ft}$ into the carbonate-rock aquifer) within the study area (Toth,1963).

\section{SUBREGIONAL SIMULATIONS}

A subregional, cross-sectional, steady-state model was constructed to simulate regional ground-water flow along a path from a potentiometric high in centralwestern Ohio to a regional potentiometric low at Sandusky Bay, on the southwestern shore of Lake Erie (Hanover, 1994) (Location of the section is shown in fig. 17 ) The specific purpose of this model was to describe quantities and locations of recharge and discharge along this flow path and to account for the apportionment of ground-water flow between the surficial and carbonate-rock aquifers along the selected path. Results of simulations made with the calibrated model indicate that about 84 percent of the water entering the groundwater-flow systems near this cross section travels less than $5 \mathrm{mi}$ from the area of recharge to the area of discharge, and that most of the flow is within the surficial aquifer (fig. 23). Traveltimes for ground-water particles calculated by use of a particle-tracking routine (Pollock, 1989) generally agreed with uncorrected carbon-14 ages for ground-water samples collected from deep wells near the model columns along the regional flow path (fig. 23). Results of this model substantiate results of the regional ground-water-flow model, namely that much of the flow in the Midwestern Basins and Arches aquifer system follows fairly short flow paths and that only a small part travels along deep, long paths from regional recharge to discharge areas.

The only area where transient conditions develop within the carbonate-rock aquifer is in northwestern Indiana, where ground-water withdrawals for irrigation impose seasonal stress on the carbonate-rock aquifer. A subregional, transient ground-water-flow model was constructed for this area (Arihood,1994) prior to the RASA study (fig. 17). Transient model results indicate that the specific storage of the carbonate-rock aquifer is $1.3 \times 10^{-4}$ and that the transmissivity ranges from 1,000 to $5,000 \mathrm{ft}^{2} / \mathrm{d}$. The transmissivity of the carbonate-rock aquifer calculated from the regional steady-state ground-water-flow model $-1,610 \mathrm{ft}^{2} / \mathrm{d}-$ is well within the ranges from transient model results, an indication that similar values of specific storage for the carbonate-rock aquifer can be applied with some confidence to other areas within the Midwestern Basins and Arches Region having similar aquifer geometry. 


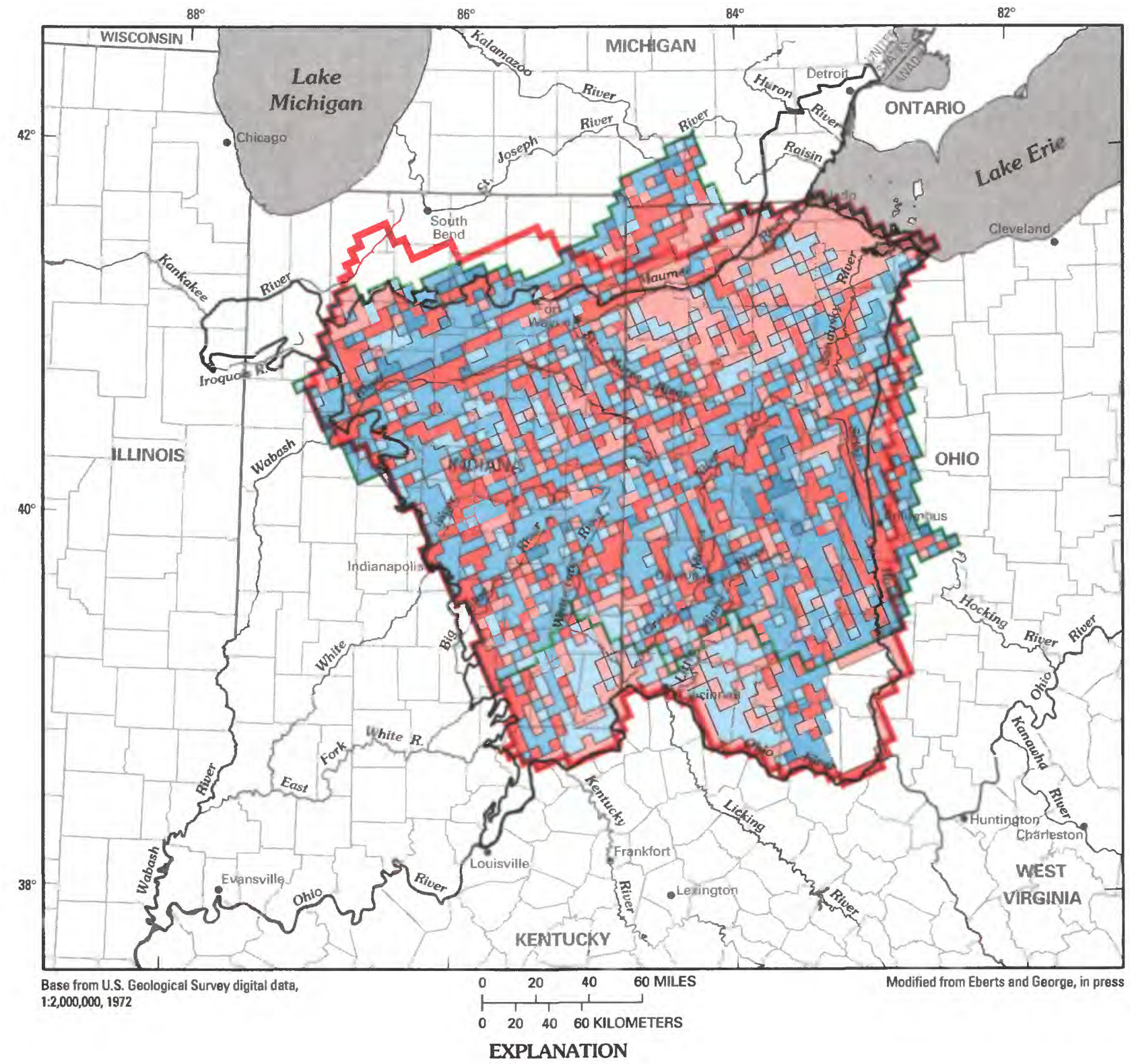

Recharge areas-Based on model output of simulated recharge, in inches per year

$$
\begin{array}{ll}
\square & 0-0.5 \\
& 0.5-4 \\
\quad \text { Greater than } 4
\end{array}
$$

Discharge areas-Based on model output of simulated discharge, in inches per year

$$
\text { … } \quad 0-0.5 \text { Greater than } 0.5
$$

Boundary of ground-water-flow model

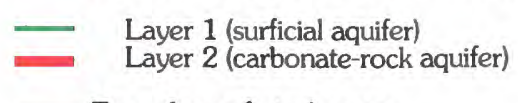

- Boundary of study area

FIGURE 21.-Recharge and discharge areas based on model output from the calibrated ground-water-flow model of the Midwestern Basins and Arches Region. 


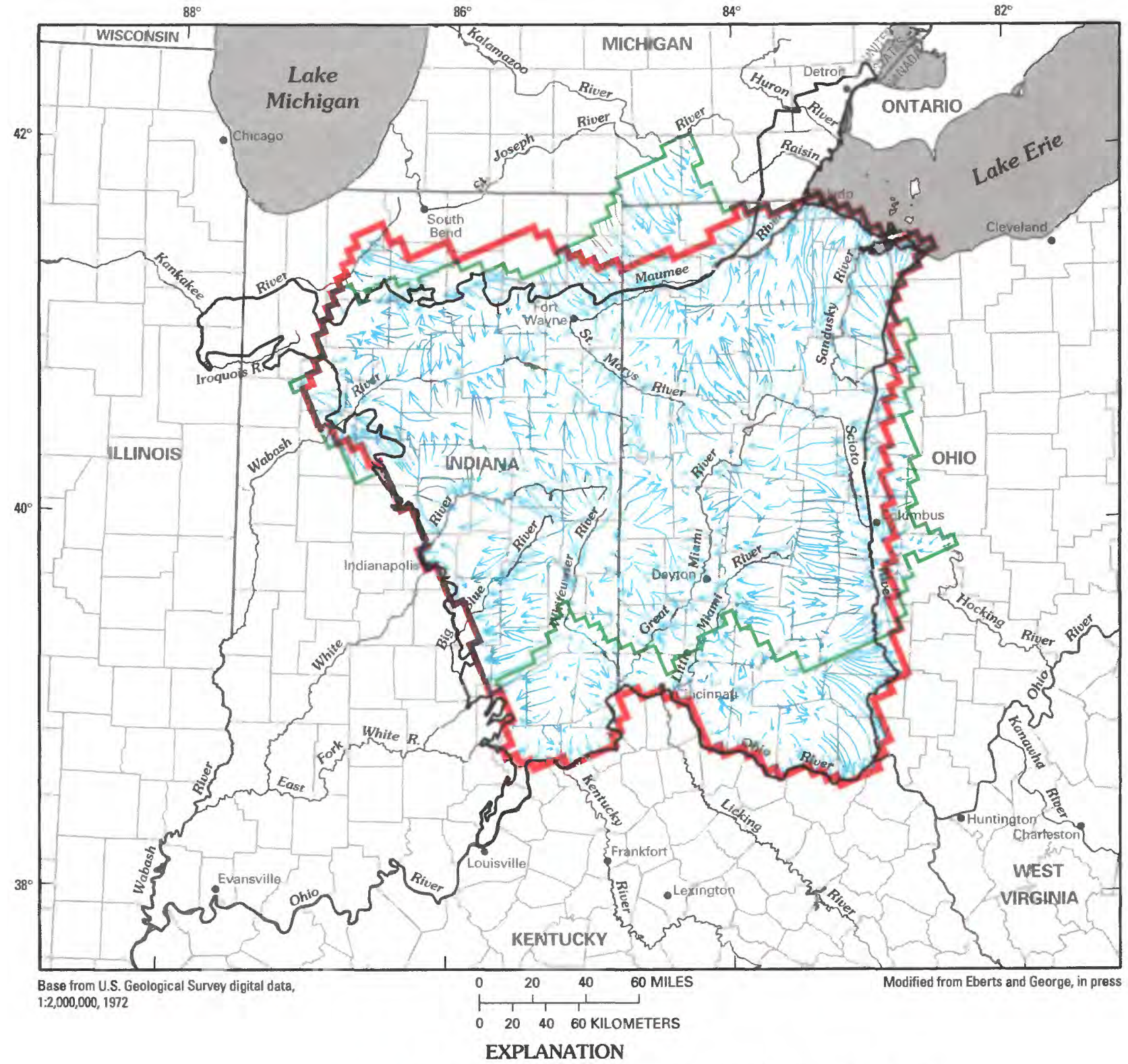

$\rightarrow$ Simulated regional ground-water-flow path-Shows path from point of regional recharge to point of regional discharge

- Boundary of model layer 1 (surficial aquifer)

Boundary of model layer 2 (carbonate-rock aquifer)

Boundary of study area

FIGURE 22.-Ground-water-flow paths based on particle tracking of regional ground-water flow in the Midwestern Basins and Arches Region. 


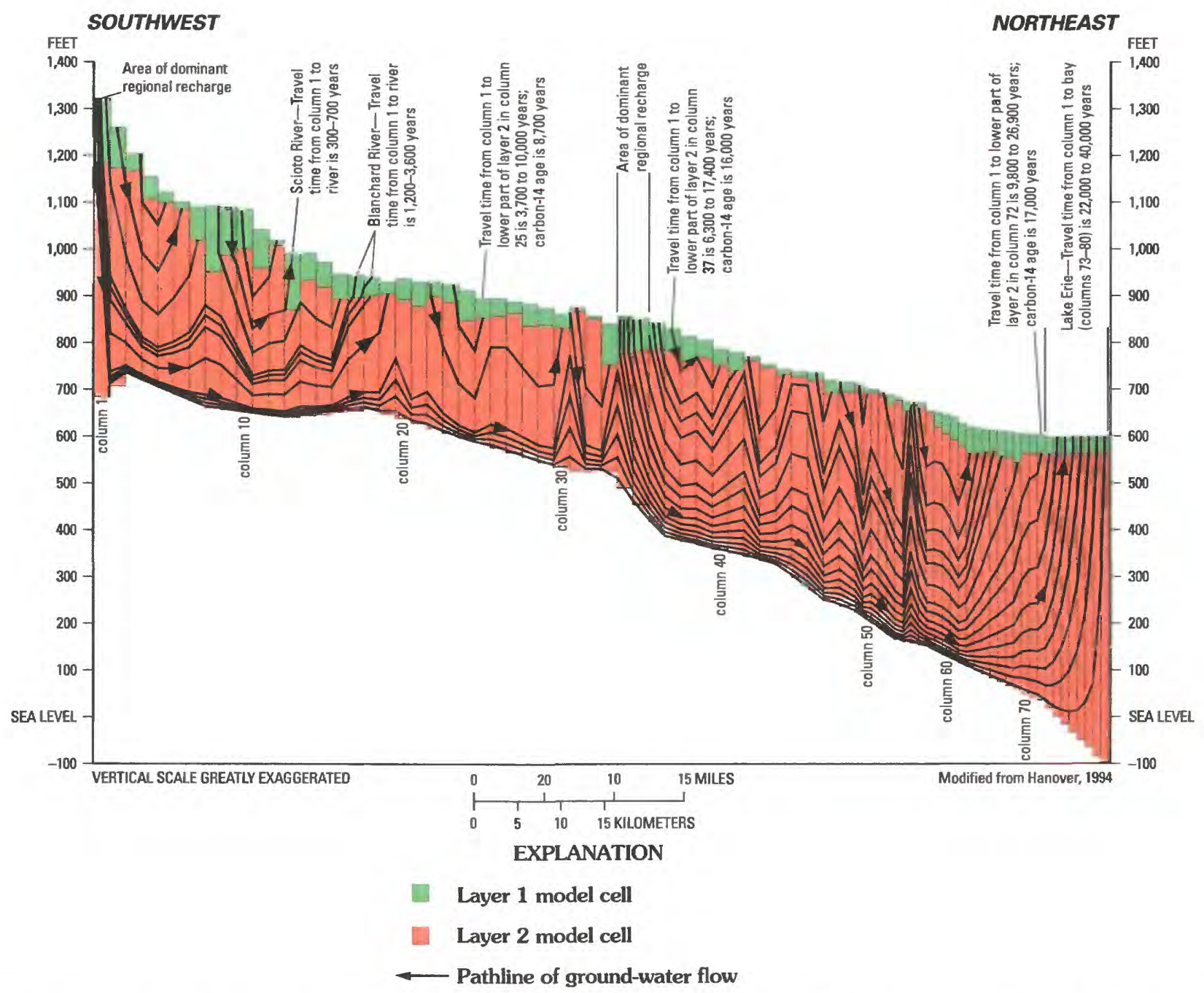

FIGURE 23.-Ground-water-flow paths based on particle-tracking results for a cross-sectional model representing regional ground-water flow from an area in central-western Ohio to a discharge area at Lake Erie (trace of section shown on figure 17).

\section{REGIONAL WATER CHEMISTRY}

The chemical character of ground water in the Midwestern Basins and Arches Region reflects the composition of the surficial deposits and carbonate bedrock and is affected by the patterns of ground-water flow through the aquifer system, especially from recharge areas to discharge areas in a carbonate-rich system. As ground water flows downgradient from regional recharge to discharge areas, the dominant anion generally changes from bicarbonate, to sulfate, to chloride; a corresponding increase in dissolved-solids concentration and the age of the water also indicate the relative lengths of the ground-water-flow paths and the associated residence time of ground water within the system (Chebotarev,1955). The changes in ground-water chemistry from recharge to discharge areas in the Midwestern Basins and Arches Region indicate that the flow systems consist mainly of short flow paths and that a complete evolution of anion species from bicarbonate to sulfate to chloride along regional flow paths is not evident in most of the study area.

\section{DISSOLVED SOLIDS TRENDS}

Distribution of dissolved-solids concentrations of ground water in the Midwestern Basins and Arches Region is similar in the surficial aquifer and the carbonate-rock aquifer within the study area where the carbonate-rock aquifer is a subcrop beneath the surficial deposits (figs. 24 and 25). The concentration of dissolved solids in ground water within the study area ranges from less than 100 to more than $2,600 \mathrm{mg} / \mathrm{L}$ in the surficial aquifer and from about 170 to $3,830 \mathrm{mg} / \mathrm{L}$ in the carbonate-rock aquifer (Eberts and George, in 
press). Dissolved solids concentrations in the carbonaterock aquifer outside of the study area (downdip, in the structural basins) range from 4,000 to more than 350,000 $\mathrm{mg} / \mathrm{L}$.

Water in the carbonate-rock aquifer with dissolved solids concentrations less than $500 \mathrm{mg} / \mathrm{L}$ is generally found in Indiana and only locally in the central part of the study area (fig. 25). Ground-water with dissolved solids concentrations less than $500 \mathrm{mg} / \mathrm{L}$ is also found locally in the northeastern part of the study area (near Lake Erie) and is associated with carbonate bedrock of Devonian age, such as that along the southern perimeter of the Michigan Basin (fig. 25). Ground water with dissolved-solids concentrations between 500 and 1,000

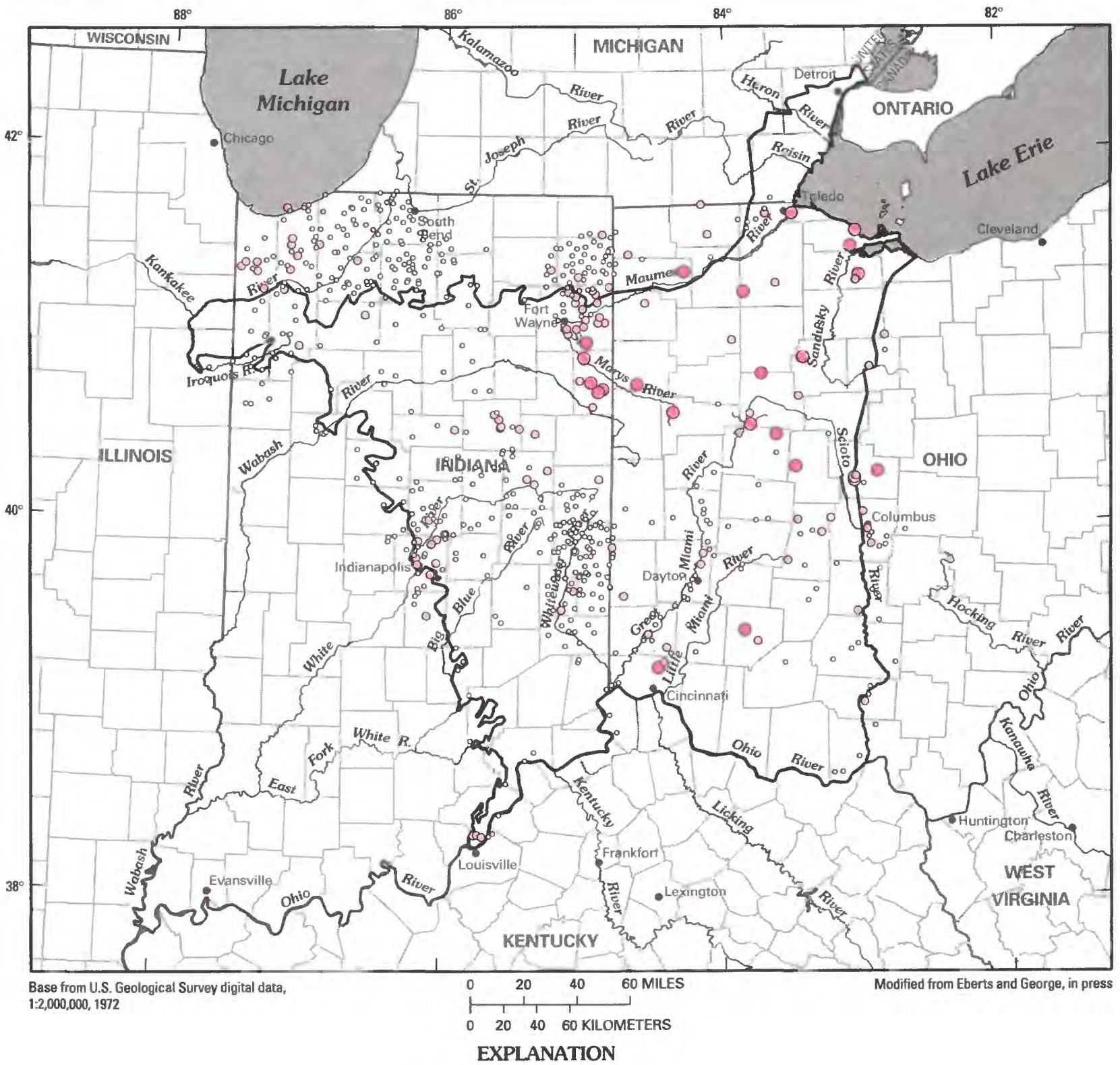

— Boundary of study area

Concentration of dissolved solids, in milligrams per liter

- $0-500$

○ $\quad 501-1,000$

- Greater than 1,000

FigURE 24.-Distribution of dissolved-solids concentrations in the surficial aquifer, Midwestern Basins and Arches Region. 


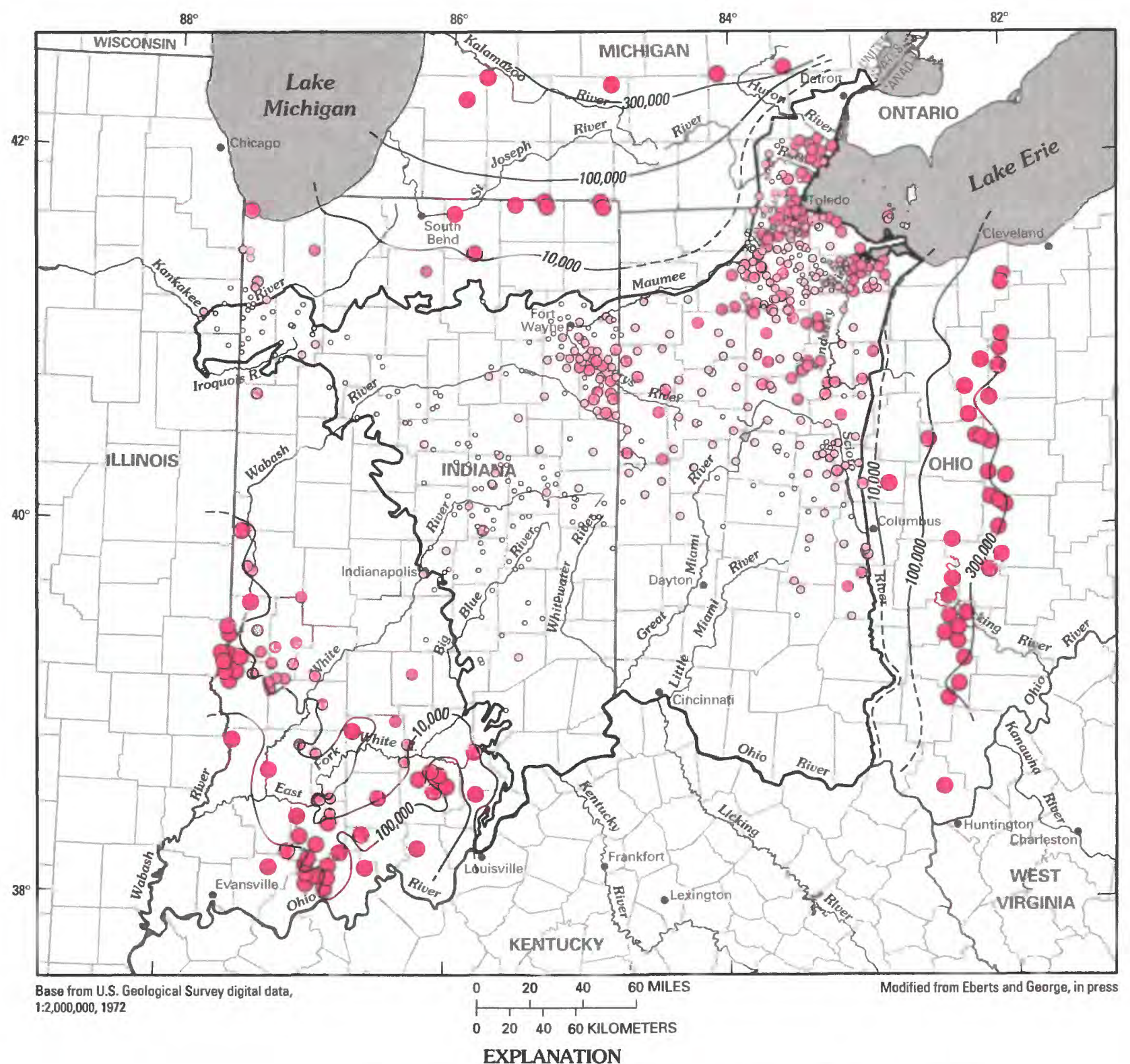
- 10,000 - Approximate line of equal dissolved-solids concentration- Dashed where inferred. Interval, in milligrams per liter, is variable

\section{Boundary of study area}

Concentration of dissolved solids, in milligrams per liter

$\begin{array}{ll}\text { - } & 0-500 \\ \text { - } & 501-1,000 \\ & 1,001-10,000 \\ \text { Greater than } 10,000\end{array}$

FIGURE 25.-Distribution of dissolved-solids concentrations in the carbonate-rock aquifer, Midwestern Basins and Arches Region. 
$\mathrm{mg} / \mathrm{L}$ is found primarily in the northeastern part of the study area (fig. 25). Water with dissolved-solids concentrations greater than $1,000 \mathrm{mg} / \mathrm{L}$ is restricted to the north-central and northeastern parts of the study area (fig. 25). Ground water with dissolved-solids concentrations greater than $10,000 \mathrm{mg} / \mathrm{L}$ is considered to be unsuitable for consumption (U. S. Environmental Protection Agency, 1984). As stated earlier in this report, the position of the $10,000 \mathrm{mg} / \mathrm{L}$ line defines the limit of the freshwater part of the carbonate-rock aquifer for this study.

Dissolved-solids concentrations greater than 10,000 $\mathrm{mg} / \mathrm{L}$ in carbonate-rock waters differ considerably in their distribution between the three structural basins (fig. 25). The Appalacian Basin exhibits the most rapid increase in dissolved-solids concentration downdip into the basin; dissolved-solids concentration of the water increases to greater than $10,000 \mathrm{mg} / \mathrm{L}$ generally within $5 \mathrm{mi}$ of the contact between the carbonate-rock aquifer and the upper confining unit. In the Michigan Basin, dissolved-solids concentrations greater than $10,000 \mathrm{mg} /$ $\mathrm{L}$ are further downdip into the basin, usually 5 to 25 miles from the contact between the carbonate-rock aquifer and the upper confining unit (fig. 25). In the Illinois Basin, the trend in dissolved-solids concentration is anomalous to trends in the Appalacian and Michigan Basins. Dissolved-solids concentrations of less than $10,000 \mathrm{mg} / \mathrm{L}$ are found more than $70 \mathrm{mi}$ downdip, from the contact between the carbonate-rock aquifer and the upper confining unit as it extends into the basin (fig. 26). Results of work by D.J. Schnoeblen (U. S. Geological Survey, written commun., 1993) indicate that fresher water (dissolved-solids concentration less than 10,000 $\mathrm{mg} / \mathrm{L}$ ) underlies saline ground water (dissolved-solids concentration greater than $10,000 \mathrm{mg} / \mathrm{L}$ ) in areas where the carbonate-rock aquifer units dip into the Illinois Basin in southwestern Indiana (figs. 1 and 25); however, the mechanism that caused and maintains this inversion is not understood, and investigation of this anomalous water-quality trend was beyond the scope of this project.

\section{HYDROCHEMICAL FACIES}

Ground water in the Midwestern Basins and Arches Region was classified into hydrochemical facies on the basis of concentrations of major cations and anions in solution reported for more than 1,300 chemical analyses of ground water from the surficial and carbonate-rock aquifers (Eberts and George, in press). The distributions of hydrochemical facies for the surficial and carbonaterock aquifers are similar (figs. 26 and 27). The most common type of water in both aquifers throughout the study area is $\mathrm{Ca}-\mathrm{Mg}-\mathrm{HCO}_{3}$. In the northeastern part of the study area where sulfate concentrations are elevated, ground water is dominated by Ca-Mg-SO - -type water. Additionally, several areas are characterized by a mixture of several ground-water types (referred to as "multiple-water-types" in figures 26 and 27).

Water in the carbonate-rock aquifer becomes sodium enriched in the northeastern, north-central, northwestern, and west-central parts of the Midwestern Basins and Arches Region near the contact between the upper confining unit shales and the carbonate-rock aquifer (fig. 27 and fig. 7). The increase in sodium and chloride ions is probably associated with either (1) mixing with more saline water in the adjacent structural basins and (or) (2) restricted recharge through the surficial aquifer to the carbonate-rock aquifer, because the upper confining unit shales inhibit direct recharge through the surficial deposits (Eberts and George, in press).

Descriptions of hydrochemical facies and processes likely controlling the development of these facies throughout the Midwestern Basins and Arches Region are summarized in table 4 . It is evident from the hydrochemical-facies maps (figs. 26 and 27) and from table 4 that the dominant process controlling the geochemistry of ground water in the Midwestern Basins and Arches Region is dissolution of limestone and dolomite into $\mathrm{Ca}-\mathrm{Mg}-\mathrm{HCO}_{3}$. The similarity of hydrochemical-facies distribution between the surficial and carbonate-rock aquifers within the study area indicates that (1) these aquifers are geochemically similar because the parent material in both aquifers was derived from the same bedrock source (Strobel and Faure, 1987) and (or) that (2) most recharge to the carbonate-rock aquifer is through the surficial deposits; thus the chemical signature from the surficial aquifer is present in waters from the carbonate-rock aquifer, owing to the hydraulic connection between them.

\section{RELATION OF ISOTOPIC COMPOSITION OF GROUND WATER TO REGIONAL FLOW}

The absence of systematic changes in dissolved-solids or sulfate concentrations in ground-water along directions of regional flow supports other hydrologic evidence that the regional aquifer system is characterized by short intermediate-length flow cells (alternating recharge and discharge areas) rather than by long regional flow paths starting at regional potentiometric highs and extending to regional potentiometric lows (Eberts and George, in press). Additional insight into chemical and hydrologic processes was gained by measuring the stable-isotope ratios, $\delta^{34} \mathrm{~S}, \delta^{18} \mathrm{O}, \delta \mathrm{D}$, and $\delta^{13} \mathrm{C}$, and estimating the age of ground water along 


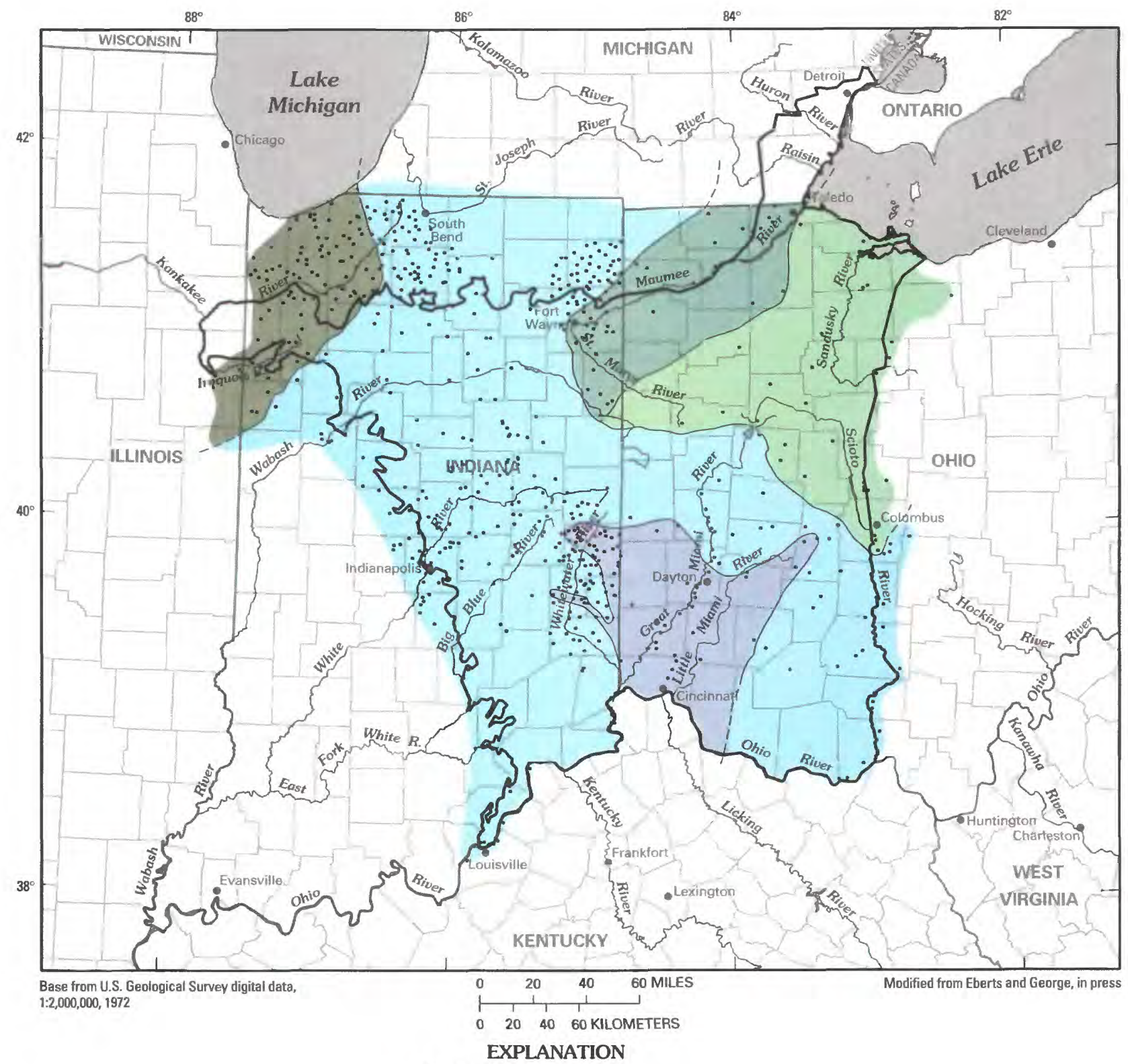

Hydrochemical facies

Predominantly single water type
$\mathrm{Ca}-\mathrm{Mg}-\mathrm{HCO}_{3}$
$\mathrm{Ca}-\mathrm{Mg}_{-}-\mathrm{SO}_{4}$

Multiple-water types

$\mathrm{Ca}-\mathrm{Mg}-\mathrm{HCO}_{3}$, Ca-Mg-Na-HCO, $\mathrm{H}_{3}$ Clinfluenced

$\mathrm{Ca}-\mathrm{Mg}-\mathrm{HCO}_{3}, \mathrm{Ca}-\mathrm{Mg}-\mathrm{SO}_{4}, \mathrm{Ca}-\mathrm{Mg}-\mathrm{Na}-\mathrm{HCO}_{3}$, and $\mathrm{Na}-\mathrm{HCO}_{3}$

$\mathrm{Ca}-\mathrm{Mg}-\mathrm{HCO}_{3}, \mathrm{Ca}-\mathrm{Mg}-\mathrm{SO}_{4}, \mathrm{Ca}-\mathrm{Mg}-\mathrm{Na}-\mathrm{HCO}_{3}, \mathrm{Na}-\mathrm{HCO}_{3}$, and $\mathrm{Ca}-\mathrm{Mg}-\mathrm{Na}-\mathrm{SO}_{4}$

- Boundary between hydrochemical facies-Dashed where inferred

Boundary of study area

- Well for which chemical data are available

FIGURE 26.-Hydrochemical facies based on concentrations of major anions and cations in water from the surficial aquifer in the Midwestern Basins and Arches Region. 


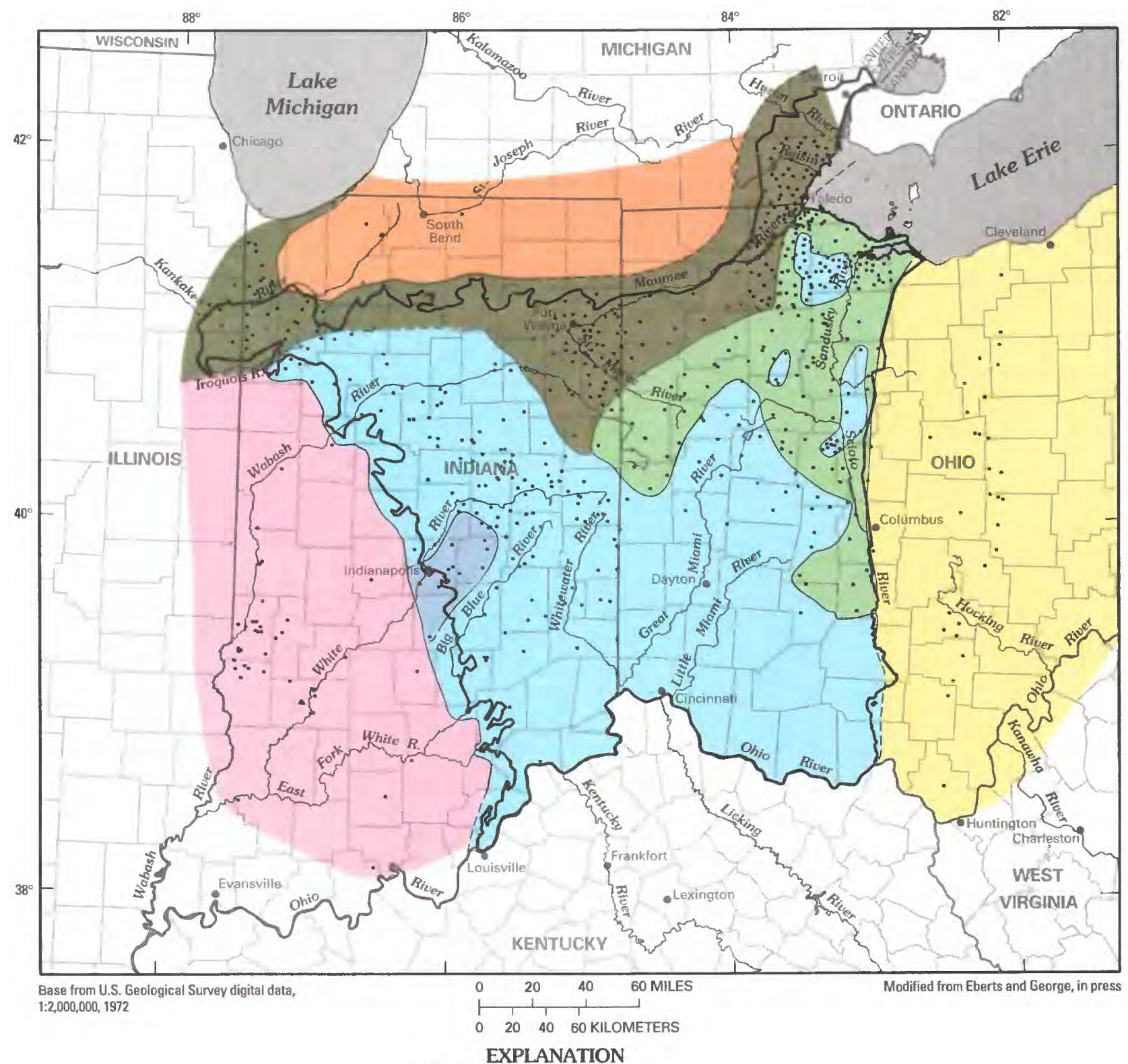

Hydrochemical facies

Predominantly single water type

$\mathrm{Ca}-\mathrm{Mg}-\mathrm{HCO}_{3}$

$\mathrm{Ca}-\mathrm{Mg}_{-}-\mathrm{SO}_{4}$

$\mathrm{Na}-\mathrm{Cl}$

$\mathrm{Na}-\mathrm{Ca}-\mathrm{Cl}$

Multiple-water types

$\mathrm{Ca}-\mathrm{Mg}-\mathrm{HCO}_{3}$ and $\mathrm{Ca}-\mathrm{Mg}-\mathrm{Na}-\mathrm{HCO}_{3}$

$\mathrm{Ca}-\mathrm{Mg}-\mathrm{HCO}_{3}, \mathrm{Ca}-\mathrm{Mg}-\mathrm{SO}_{4}, \mathrm{Ca}-\mathrm{Mg}-\mathrm{Na}-\mathrm{HCO}_{3}, \mathrm{Na}-\mathrm{HCO}$, and $\mathrm{Ca}-\mathrm{Mg}-\mathrm{Na}-\mathrm{SO}_{4}$

$\mathrm{Na}-\mathrm{Cl}$ and $\mathrm{Na}-\mathrm{Ca}-\mathrm{Cl}$

- - Boundary between hydrochemical facies-Dashed where inferred

- Boundary of study area

- Well for which chemical data are available

FIGURE 27.-Hydrochemical facies based on concentrations of major anions and cations in water from the carbonate-rock aquifer in the Midwestern Basins and Arches Region. 
TABLE 4.-Hydrochemical facies, geochemical processes controlling reactions, and predominant areas of hydrochemical facies in the surficial and carbonate-rock aquifers in the Midwestern Basins and Arches Region

\begin{tabular}{|c|c|c|}
\hline Hydrochemical facies & Processes likely controlling chemical reactions & Predominant area of hydrochemical facies \\
\hline \multicolumn{3}{|c|}{ Surficial aquifer } \\
\hline \multicolumn{3}{|c|}{ Single water type } \\
\hline $\mathrm{Ca}-\mathrm{Mg}-\mathrm{HCO}_{3}$ & Dissolution of calcite and dolomite & Most of study area, predominantly in central part \\
\hline \multicolumn{3}{|c|}{ Multiple water type } \\
\hline $\begin{array}{l}\mathrm{Ca}-\mathrm{Mg}-\mathrm{HCO}_{3} ; \mathrm{Ca}-\mathrm{Mg}-\mathrm{SO}_{4} ; \\
\mathrm{Ca}-\mathrm{Mg}-\mathrm{Na}-\mathrm{HCO}_{3} ; \mathrm{Na}-\mathrm{HCO}_{3} ; \\
\text { Ca-Mg-Na-SO }\end{array}$ & $\begin{array}{l}\text { Cation exchange and dissolution of calcite and } \\
\text { dolomite }\end{array}$ & $\begin{array}{l}\text { North-central part of study area, principally in } \\
\text { northeastern Ohio along contact between } \\
\text { Devonian carbonate and shale rocks }\end{array}$ \\
\hline \multicolumn{3}{|c|}{ Carbonate-rock aquifer } \\
\hline \multicolumn{3}{|c|}{ Single water type } \\
\hline $\mathrm{Ca}-\mathrm{Mg}-\mathrm{HCO}_{3}$ & Dissolution of calcite and dolomite & Most of study area, predominantly in central part \\
\hline $\mathrm{Ca}-\mathrm{Mg}-\mathrm{SO}_{4}$ & $\begin{array}{l}\text { Dedolimitization and dissolution of dolomite } \\
\text { by sulfuric acid from oxidized pyrite }\end{array}$ & Northeastern part of study area \\
\hline \multicolumn{3}{|c|}{ Multiple water type } \\
\hline $\begin{array}{l}\mathrm{Ca}-\mathrm{Mg}-\mathrm{HCO} ; \mathrm{Ca}-\mathrm{Mg}-\mathrm{SO}_{4} ; \\
\mathrm{Ca}-\mathrm{Mg}-\mathrm{Na}-\mathrm{HCO}_{3} ; \mathrm{Na}-\mathrm{HCO}_{3} ; \\
\mathrm{Ca}-\mathrm{Mg}-\mathrm{Na}-\mathrm{SO}_{4}\end{array}$ & $\begin{array}{l}\text { Cation exchange and dissolution of calcite and } \\
\text { dolomite }\end{array}$ & $\begin{array}{l}\text { Northern part of study area along the contact } \\
\text { between Devonian carbonate and shale rock; } \\
\text { along the margins of the Michigan Basin where } \\
\text { the carbonate-rock aquifer is overlain by } \\
\text { Devonian shales }\end{array}$ \\
\hline
\end{tabular}

directions of regional ground-water flow (from regional recharge areas to regional discharge areas) by use of the radioactive isotopes ${ }^{14} \mathrm{C}$ and tritium (Eberts and George, in press).

Values of $\delta^{34} \mathrm{~S}$ in ground-water samples collected from wells in the study area ranged from -10.4 permil to +44.1 permil for $\delta^{34} \mathrm{~S}_{\text {(sulfate) }}$ and from -53.2 permil to 12.2 permil for $\delta^{34} \mathrm{~S}_{\text {(sulfide) }}$ (Eberts and George, in press). The heaviest $\delta^{34} \mathrm{~S}_{\text {(sulfate) }}$ values were most commonly found in the northeastern part of the study area in association with gypsum deposits of Silurian and Devonian age; lighter $\delta^{34} \mathrm{~S}_{\text {(sulfate) values were generally found in }}$ the western part of the study area where gypsum beds are absent from the carbonate bedrock. In addition $\delta^{34} \mathrm{~S}_{\text {(sulfate) }}$ values for ground-water from the surficial aquifer tended to be lighter than those for ground water from deep in the carbonate-rock aquifer, an indication that recharge entering the surficial aquifer and the fractured, uppermost part of the carbonate-rock aquifer does not reach the deeper parts of the regional system (Eberts and George, in press).

Values of $\delta^{18} \mathrm{O}$ and $\delta \mathrm{D}$ were determined for water samples collected from wells in the surficial and carbonate-rock aquifers in the study area in the Midwestern Basins and Arches Region to determine relative ages of recharge to the regional ground-water system (Eberts 
and George, in press). Isotopic compositions of most ground-water samples were similar to those of surface water sampled in the study area, an indication that climatic conditions at the time of recharge to the regional ground-water-flow system were likely similar to present climatic conditions. Moreover, water from wells in most parts of the study area contains enough tritium to indicate that the regional aquifer system in these areas is relatively active with respect to flow and that it has been recharged since atmospheric testing of nuclear weapons began in 1953. In contrast, isotopically light ground-water from wells in the northeastern part of the study area indicate that water likely recharged the regional aquifer system during climatic conditions colder than the present, perhaps during Pleistocene time. Additionally, tritiated water was not detected in any of the isotopically light ground-water samples in the northeastern part of the study area (Eberts and George, in press), an indication that recharge has not entered the regional ground-water system in this area since 1953.

Carbon-14 ages were determined for samples from wells in the surficial and carbonate-rock aquifers; $\delta^{13} \mathrm{C}$ data also were collected to provide information regarding sources of dissolved inorganic carbon in ground water so that measured ${ }^{14} \mathrm{C}$ values could be corrected for the dilutional effects caused by various geochemical processes. The ${ }^{14} \mathrm{C}$ data indicate that ground water throughout most of the study area is relatively young, from a few hundred to several thousand years old; the oldest ground water (about $38,000-45,000$ years old) is in the northeastern part of the study area (within the Maumee River Basin and adjacent to Lake Erie), near the regional discharge area surrounding the Wabash River in northern Indiana, and at the margin of the Illinois Basin in western Indiana (Eberts and George, in press). These data corroborate ground-water-flow-modeling results indicating that the Maumee River Basin, Lake Erie, and the Wabash River are regional groundwater-discharge areas, and support the conclusion that recharge is restricted in this area, probably by surficial lacustrine deposits. Ground water discharging in these areas has traveled deeper within the regional system along somewhat longer flow paths and is thus older than most water within the surficial and carbonate-rock aquifers in the Midwestern Basins and Arches Region. Carbon-14 data indicate that relatively old water (about
13,000 years old) is at the end of the longest flow paths (50 miles) near Lake Erie.

\section{GROUND-WATER USE}

The amount of ground water withdrawn for various uses was estimated from ground-water-pumpage data reported by users in 1990 capable of pumping 100,000 $\mathrm{gal} / \mathrm{d}$ or more (Bill Steen, Indiana Department of Natural Resources, Division of Water and Rebecca Petty, Ohio Department of Natural Resources, Division of Water, written communs., 1992) (fig. 28). To account for all other ground-water users (those that pumped less than $100,000 \mathrm{gal} / \mathrm{d}$ in 1990) would increase the total substantially; however, these data were not available. The reported ground-water use data can be considered conservative estimates of the types and rates of groundwater withdrawals in the Midwestern Basins and Arches Region in 1990.

An average of $433 \mathrm{Mgal} / \mathrm{d}$ of ground water was withdrawn from the surficial and carbonate-rock aquifers in Indiana and Ohio during 1990 (Beary, 1993). In contrast, about $280 \mathrm{Mgal} / \mathrm{d}$ was withdrawn from the aquifers in 1980 (Bugliosi, 1990), an increase of almost 65 percent in 10 years. The reported increase in groundwater use is probably due at least, in part, to changes in reporting policies and user compliance with those reporting policies from 1980 to 1990 . Monthly total ground-water withdrawals in the Indiana and Ohio parts of the study area exhibited a seasonal trend in 1990 (fig. 29); monthly withdrawals in Ohio ranged from 6,800 Mgal (February) to about 12,000 Mgal (August), whereas those in Indiana ranged from 4,300 Mgal (February) to about 8,000 Mgal (July).

The greatest use in a particular category (more than 65 percent) of ground water within the Indiana and Ohio parts of the study area in 1990 was for public supply (180.8 Mgal/d) (fig. 30). Industrial and energy-production uses followed ( 21 and 6 percent, respectively), with agriculture/irrigation, miscellaneous and rural use accounting for the remainder (about 8 percent). The percentages of ground-water use for the various categories are similar to those for 1980 (Bugliosi, 1990), an indication that ground-water-use trends remained steady during 1980-90 within the Midwestern Basins and Arches Region. 


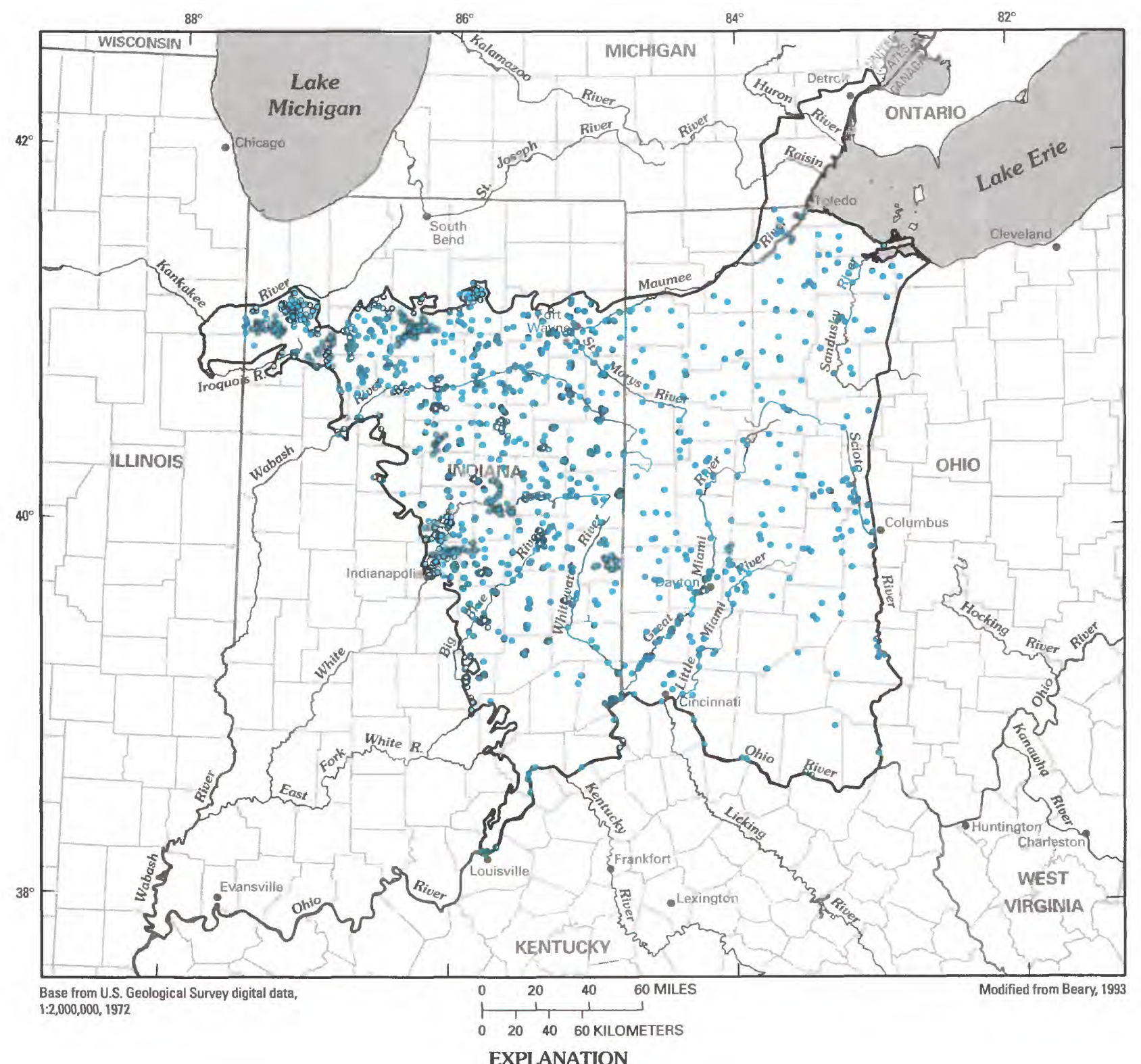

- Boundary of study area

- Ground-water-withdrawal site-Locations reported from Ohio and Indiana State agencies

FiguRE 28.-Ground-water-withdrawal sites where potential pumpage is 100,000 gallons per day or more in the Midwestern Basins and Arches Region. 


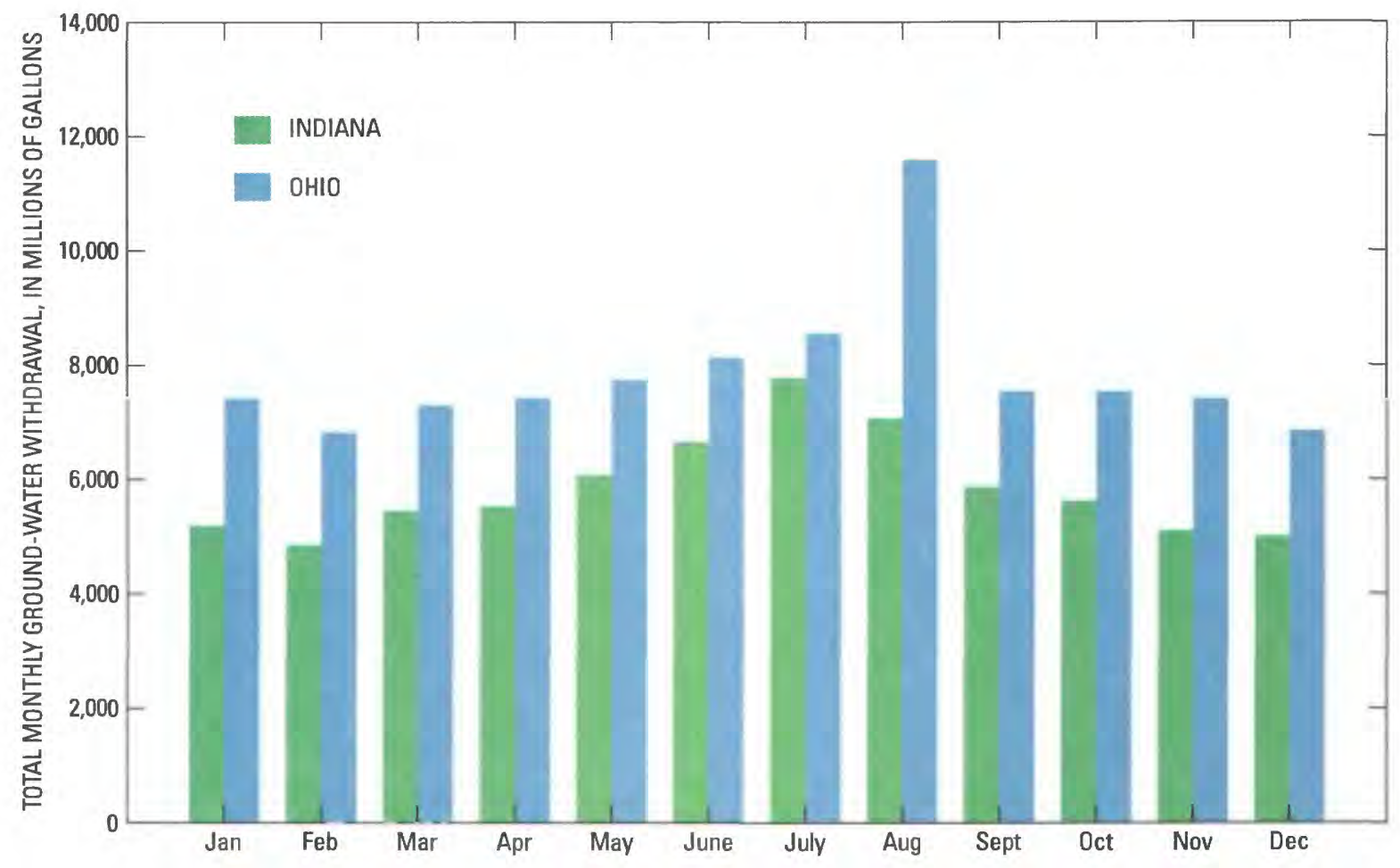

FIGURE 29.-Total monthly ground-water withdrawals for parts of Indiana and Ohio in the Midwestern Basins and Arches Region, 1990 (modified from Beary, 1993).

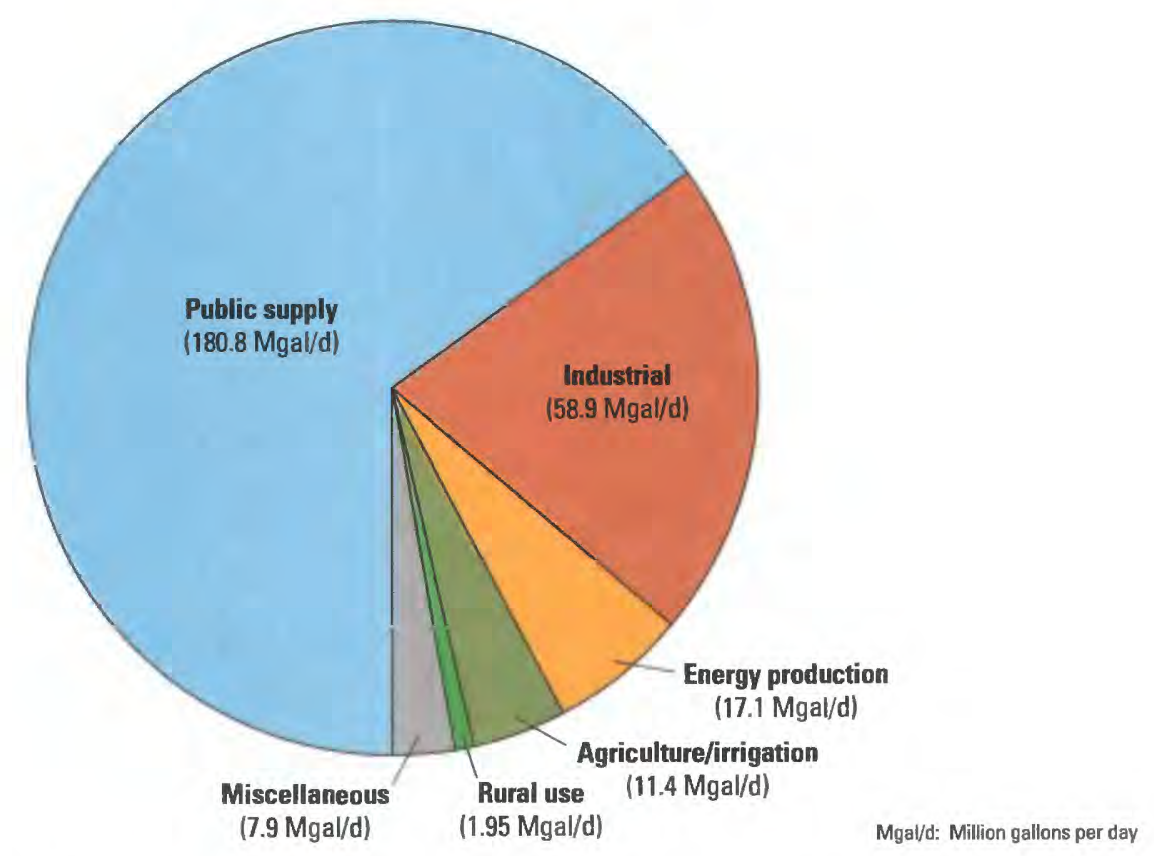

FIGURE 30,-Total monthly ground-water use, by category, among users capable of withdrawing 100,000 gallons per day or more in parts of Indiana and Ohio within the Midwestern Basins and Arches Region, 1990 (modified from Beary, 1993). 


\section{REFERENCES CITED}

(These and other reports prepared as part of the Midwestern Basins and Arches RASA project are indicated by an asterisk $\left(^{*}\right)$ next to the reference.)

*Arihood, L.D., 1994, Hydrogeology and paths of flow in the carbonate bedrock aquifer, northwestern Indiana: Water-Resources Bulletin, v. 30, no. 2, p. 205-218.

Arihood, L.D. and Basch, M.E.,1994, Geohydrology and simulated ground-water flow in an irrigated area of northwestern Indiana: U.S. Geological Survey Water Resources Investigations Report 92-4046, 38 p.

Ault, C.H., Becker, L.E., Droste, J.B., Keller, S.J., and Shaver, R.H., 1976, Map of Indiana showing thickness of Silurian rocks and location of reefs and reef-induced structures: Indiana Department of Natural Resources, Geological Survey Miscellaneous Map 22, scale 1:500,000.

Baker, D.B., Wallrabenstein, L.K., Richards, R.P., and Creamer, N.L., 1989, Nitrate and pesticides in private wells of Ohio-a state atlas: Tiffin, Ohio, Heidelberg College Water Quality Laboratory, $304 \mathrm{p}$.

*Beary, E.A., 1993, Ground-water withdrawal in 1990-Midwestern Basins and Arches regional aquifer systems study area: U.S. Geological Survey Open-file report 93-119 [Water Fact Sheet], $2 \mathrm{p}$.

Beaumont, Christopher, Quinlan, Garry, and Hamilton, Juliet, 1988, Orogeny and stratigraphy: Numerical models of the Paleozoic in the eastern interior of America: Tectonics, v. 7, no. 3, p. 389-416.

Bennisson, A.P., comp., 1978, Geological highway map of the Great Lakes Region: American Association of Petroleum Geologists, U.S. Geological Highway Map Series, Map 11.

Bingham, J.M., Smeck, N.E., Norton, L.D., Hall, G.F., and Thompson, M.L., 1991, Lithology and general stratigraphy of Quaternary sediments in a section of the Teays River Valley of southern Ohio, in Melhorn,W.N., and Kempton, J.P., eds., Geology and hydrology of the Teays-Mahomet Bedrock Valley System: Boulder Colo., Geological Society of America Special Paper 258, p. $19-27$.

Bleuer, N.K., 1991, The Lafayette Bedrock Valley System of Indiana-concept, form, and fill stratigraphy, in Melhorn, W.N., and Kempton, J.P., eds., Geology and hydrology of the TeaysMahomet Bedrock Valley System: Boulder, Colo., Geological Society of America Special Paper 258, p. 51-77.

Bloyd, R.M. Jr., 1974, Summary appraisals of the Nation's groundwater resources-Ohio region: U.S. Geological Survey Professional Paper 813-A, 41 p.

Bownocker, J.A., comp., 1920 [1981], Geologic map of Ohio: Ohio Geological Survey, scale 1:500,000.

Breen, K.J., and Dumouchelle, D.H., 1992, Geohydrology and quality of water in aquifers in Lucas, Sandusky, and Wood Counties, northwestern Ohio: U.S. Geological Survey Water-Resources Investigations Report 91-4024, $234 \mathrm{p}$.

*Bugliosi, E.F., 1990, Plan of study for the Ohio-Indiana carbonatebedrock and glacial-aquifer system: U.S. Geological Survey Open File Report 90-151, 26 p., 1 plate.

Burger, A.M., Forsyth, J.L, Nicoll, R.S., and Wayne, W.J., 1971, Geological map of the $\mathrm{I}^{\prime} \times 2^{\prime}$ Muncie quadrangle, Indiana and Ohio, showing bedrock and unconsolidated deposits: Indiana Department of Natural Resources, Geological Survey Regional Geologic Map 5, Muncie sheet, parts A and B, scale 1:250,000.
*Casey, G.D., 1997, Hydrogeologic framework of the Midwestern Basins and Arches region in parts of Indiana, Ohio, Michigan, and Illinois: U.S. Geological Survey Professional Paper 1423B, 46 p., 1 plate.

Chebotarev I.I., 1955, Metamorphism of natural waters in the crust of weathering: Geochemica et Cosmochimica Acta, v. 8, p. 22-48.

Clark, G.D., ed., 1980, The Indiana water resource-availability, uses, and needs: Indianapolis, Governor's Water Resources Study Commission, Indiana Department of Natural Resources, $508 \mathrm{p}$.

Cravens, S.J., Wilson, S.D., and Barry, R.C., 1990, Regional assessment of the ground-water resources in eastern Kankakee and northern Iroquois counties: Illinois State Water Survey Report of Investigation 111, p. 22, 23.

Daniels, D.P., Fritz, S.J., Leap, D.I., 1991, Estimating recharge rates through unsaturated glacial till by tritium tracing: Ground Water, v. 29 , no. 1, p. 26-34.

Droste, J.B., Shaver, R.H., and Lazor, J.D., 1975, Middle Devonian paleogeography of the Wabash Platform, Indiana, Illinois, and Ohio: Geology, v. 3, p. 269-272.

Droste, J.B., and Shaver, R.H., 1983, Atlas of early and middle Paleozoic paleogeography of the southern Great Lakes area: Indiana Department of Natural Resources, Geological Survey Special Report 32, $32 \mathrm{p}$.

1985, Comparative stratigraphic framework for Silurian reefs-Michigan Basin to surrounding platforms: Michigan Basin Geological Society Special Paper 4, p. 73-93.

Dumouchelle, D.H., Schalk, C.W., Rowe, G.L., and de Roche, J.T., 1993, Hydrogeology, simulated ground-water flow, and ground-water quality, Wright-Patterson Air Force Base, Ohio: U.S. Geological Survey Water-Resources Investigations Report 93-4047, $152 \mathrm{p}$.

*Eberts, S.M., in press, Water levels and ground-water discharge, regional aquifer system of the Midwestern Basins and Arches Region in parts of Indiana, Ohio, Illinois, and Michigan: U.S. Geological Survey Hydrologic Investigations Atlas 725, Scale $1: 2,000,000,3$ sheets.

Eberts, S.M. and George. L.L., in press, Regional ground-water flow and geochemistry in the Midwestern Basins and Arches aquifer system in parts of Indiana, Ohio, Illinois, and Michigan: U.S. Geological Survey Professional Paper 1423-C.

Ettensohn, F.R., 1985, The Catskill Delta complex and the Acadian Orogeny-A model; in Woodrow, D.L., and Sevon, W.D., eds. The Catskill Delta: Boulder Colo., Geological Society of America Special Paper 201, p. 39-49.

Fenelon, J.M., Bobay, K. E., and others, 1994, Hydrogeologic atlas of aquifers in Indiana: U.S. Geological Survey Water-Resources Investigations Report 92-4142, $197 \mathrm{p}$.

Fenneman, N.M., 1938, Physiography of eastern United States: New York, McGraw-Hill Inc., 714 p.

Flint, R.F., 1971, Glacial and Quaternary geology: New York, John Wiley and Sons, $892 \mathrm{p}$.

Freeze, R.A., and Witherspoon, P.A., 1967, Theoretical analysis of regional groundwater flow, 2. Effect of water-table configuration and subsurface permeability variation: Water Resources Research, v. 3, no. 2, p. 623-634.

Fullerton, D.S., 1986, Stratigraphy and correlation of glacial deposits from Indiana to New York and New Jersey, in Sibrava, V., Bowen, D.Q. and Richmond, G.M., Quaternary glaciations in the northern hemisphere: Oxford, England, Report of the International Geological Correlation Programme, Project 24 (International Union of Geological Sciences and UNESCO), Quaternary Science Review, v. 5, p. 23-37.

Geosciences Research Associates Inc., 1982, Hydrogeologic atlas of Indiana: Bloomington, Ind., Fine Print, 31 plates. 
Goldthwait, R.P., 1991, The Teays Valley problem-A historical perspective, in Melhorn, W.N., and Kempton, J.P., eds., Geology and hydrology of the Teays-Mahomet Bedrock Valley System: Boulder, Colo., Geological Society of America Special Paper 258, p. 3-8.

Gray, H.H., 1972, Lithostratigraphy of the Maquoketa Group (Ordovician) in Indiana: Indiana Department of Natural Resources, Geological Survey Special Report 7,31 p.

1979, The Mississippian and Pennsylvanian (Carboniferous) Systems in the United States-Indiana: U.S. Geological Survey Professional Paper 1110-K, $20 \mathrm{p}$.

1991, Origin and history of the Teays drainage system-the view from midstream, in Melhorn, W.N., and Kempton, J.P., eds., Geology and hydrology of the Teays-Mahomet Bedrock Valley System: Boulder, Colo., Geological Society of America Special Paper 258, p. 43-50.

Gray, H.H., Ault, C.H., and Keller, S.J., 1987, Bedrock geologic map of Indiana: Indiana Department of Natural Resources, Indiana Geological Survey Miscellaneous Map 48, scale 1:500,000.

Gray, H.H., Forsyth, J.L., Schneider, A.F., and Gooding, A.M., 1972, Geologic map of the Cincinnati quadrangle, Indiana and Ohio, showing bedrock and unconsolidated deposits: Indiana Geological Survey Regional Geologic Map 7, Cincinnati sheet, part A, scale 1:250,000.

Gray, H.H., Droste,J.B., Patton, J.B., Rexroad, C.B., and Shaver, R.H., 1985, Correlation chart showing Paleozoic stratigraphy units of Indiana: Indiana Department of Natural Resources, Geological Survey Supplement to Miscellaneous Map 48.

Gupta, Neeraj, 1993, Geologic and fluid-density controls on the hydrodynamics of the Mt. Simon sandstone and overlying geologic units in Ohio and surrounding states: Columbus, Ohio, The Ohio State University, Ph.D. dissertation, 266 p.

*Hanover, R.H., 1994, Analysis of ground-water flow along a regional flow path of the Midwestern Basins and Arches aquifer system in Ohio: U.S. Geological Survey Water-Resources Investigations Report 94-4105, 29 p.

Hill, M.C., 1992, A computer program (MODFLOWP) for estimating parameters of a transient, three-dimensional, ground-water flow model using nonlinear regression: U.S. Geological Survey Open-File Report 91-484, 358 p.

1994, Five computer programs for testing weighted residuals and calculating linear confidence and prediction intervals on results from the ground-water parameter-estimating computer program MODFLOWP: U.S. Geological Survey OpenFile Report 93-481, 81 p.

Hoover, K.V., 1960, Devonian-Mississippian shale sequence in Ohio: Ohio Department of Natural Resources, Geological Survey Information Circular 27, $154 \mathrm{p}$.

Hull, D.N., 1990, Generalized column of bedrock units in Ohio: Ohio Department of Natural Resources, Geological Survey, 1 plate.

Indiana Department of Natural Resources, 1988, Water resource availability in the Whitewater River Basin, Indiana: Division of Water, Water Resource Assessment 88-2, 126 p.

1990, Water resource availability in the Kankakee River Basin, Indiana: Division of Water, Water Resource Assessment 90-3, $247 \mathrm{p}$.

Janssens, Adriaan, 1977, Silurian rocks in the subsurface of northwestern Ohio: Ohio Department of Natural Resources, Geological Survey Report of Investigations 100, $96 \mathrm{p}$.

Janssens, Adriaan, and de Witt, Wallace Jr., 1976, Potential natural gas resources in the Devonian shales in Ohio: Ohio Department of Natural Resources, Geological Survey, Geological Note 3, $12 \mathrm{p}$.

*Joseph, R.L., and Eberts, S.M., 1994, Selected data on characteristics of glacial deposit and carbonate-rock aquifers, Midwestern
Basins and Arches Region: U.S. Geological Survey Open-File Report 93-627, 43 p.

Kaatz, M.R., 1952, The settlement of the Black Swamp of northwestern Ohio: Ann Arbor, Mich., University of Michigan, Ph.D. dissertation, $158 \mathrm{p}$.

Keller, S.J, 1983, Analyses of subsurface brines of Indiana: Indiana Department of Natural Resources, Geological Survey Occasional Paper 41, $30 \mathrm{p}$.

Laferriere, A.P., Hattin, D.E., Foell, C.J., and Abdulkareem, T.F., 1986, The Ordovician-Silurian unconformity in southeastern Indiana: Indiana Department of Natural Resources, Geological Survey Occasional Paper 53, 12 p.

Larsen, G.E., 1991, Development of Silurian and Devonian lithostratigraphic nomenclature, central-western and northwestern Ohio: Ohio Department of Natural Resources, Geological Survey Open-File Report 91-1, 1 pl.

Mandle, R.J. and Kontis, A.L., 1992, simulation of regional groundwater flow in the Cambrian-Ordovician aquifer system in the northern midwest, United States: U.S. Geological Survey Professional Paper 1405-C, 97p.

Melhorn, W.N., and Smith, N. M., 1959, The Mt. Carmel Fault and related structural features in south-central Indiana: Indiana Geological Survey Report of Progress 16, 29 p., 1 pl.

Milstein, R.A., 1987, Bedrock geology of Michigan: Michigan Department of Natural Resources, Geological Survey, scale $1: 500,000$.

Norris, S.E., 1974, Regional flow system and ground-water quality in western Ohio: U.S. Geological Survey Journal of Research, v. 2, no. 5 , p. 527-531.

Norris, S.E., and Fidler, R.E., 1973, Availability of water from limestone and dolomite aquifers in southwest Ohio and the relation of water quality to the regional flow system: U.S. Geological Survey Water-Resources Investigations Report 1773,42 p.

Ohio Department of Natural Resources, Division of Water, 1970, Ground water for planning in northwest Ohio, a study of the carbonate rock aquifers: Ohio Water Plan Inventory Report $22,63 \mathrm{p}$.

Onasch, C.M., and Kahle, C.F., 1991, Recurrent tectonics in a cratonic setting -an example from Northwestern Ohio: Geological Society of America Bulletin, v. 103, p. 1259-1269.

Pettyjohn, W.A., and Henning, R.J., 1979, Preliminary estimate of regional effective ground-water recharge rates in Ohio: Columbus, Ohio State University, Water Resources Center, Project Completion Report 552, 323 p.

Pollock, D.W., 1989, Documentation of computer programs to compute and display pathlines using results from the U.S. Geological Survey modular three-dimensional finite-difference ground-water flow model: U.S. Geological Survey Open-File Report 89-381, $188 \mathrm{p}$.

Rexroad, C.B., and Droste, J.B., 1982, Stratigraphy and conodont paleontology of the Sexton Creek Limestone and the Salamonie Dolomite (Silurian) in northwestern Indiana: Indiana Department of Natural Resources, Geological Survey Special Report $25,29 \mathrm{p}$.

Roadcap, G.S., Cravens, S.J., and Smith, E.C., 1993, Calculating ground-water recharge rates to the Silurian dolomite aquifer in northeastern Illinois [abs.], in 38th Annual Midwest Ground Water Conference, Program and Abstracts: p. 53.

Rosenshein, J.S., 1963, Recharge rates of principal aquifers in Lake County, Indiana: Ground Water, v. 1, no. 4, p. 4-20.

Rowland, M.R., and Kunkle, G.R., 1970, Cones of influence developed in the Silurian-Devonian aquifer, Maumee River basin, Ohio: Ground Water, v. 8, no. 3, p. 37-43. 
Rupp, J.A., 1991, Structure and isopach maps of the paleozoic rocks of Indiana: Indiana Department of Natural Resources, Geological Survey Special Report 40, 48 p.

Rupp, J.A., and Pennington, Dean, 1987, Determination of the 10,000 $\mathrm{mg} / \mathrm{L}$ TDS surface within the bedrock aquifers of Indiana: Indianapolis, Ind., Indiana Academy of Science Proceedings, v. 97, p. 383-389.

Shaver, R.H., 1974, The Muscatatuck Group (new Middle Devonian name) in Indiana: Indiana Department of Natural Resources, Geological Survey Occasional Paper 3, 7 p.

Shaver, R.H., regional coordinator, 1985, Midwestern Basin and Arches Region-correlation of stratigraphic units of North America (COSUNA) project: American Association of Petroleum Geologists, 1 sheet.

Shaver, R.H.; Ault, C.H.; Burger, A.M.; Carr, D.D.; Droste, J.B.; Eggert, D.L.; Gray, H.H.; Harper, Denver; Hasenmueller, N.R.; Hassenmueller, W.A.; Horowitz, A.S.; Hutchison, H.C.; Keith, B.D.; Keller, S.J.; Patton, J.B.; Rexroad, C.B.; and Wier,C.E., 1986, Compendium of paleozoic rock-unit stratigraphy in Indiana-a revision: Indiana Department of Natural Resources, Geological Survey Bulletin 59, 203 p.

Shaver, R.H., and Austin, G.S., 1972, A field guide to the Mt. Carmel Fault of southern Indiana: Indiana Department of Natural Resources, Geological Survey Guidebook 13, 25 p.

Sheets, R.A., and Yost, W.P., 1994, Ground-water contribution from the Silurian/Devonian carbonate aquifer in the Mad River Basin, southwestern Ohio: Ohio Journal of Science, v. 94, no. 5, p. 138-146.

Shindel, H.L., Klingler, J.H., Mangus, J.P., and Trimble, L.E., 1991a, Water resources data, Ohio, water year 1990: U.S. Geological Survey Water-Data Report OH-90-1, 305 p.

1991b, Water resources data, Ohio, water year 1990: U.S. Geological Survey Water-Data Report OH-90-2, 281 p.

Stith, D.A., 1979, Brine analyses, 1972-1974: Ohio Department of Natural Resources, Division of Geological Survey Open- File Report 79-1, 75 p.

Soller, D.R., 1986, Prelimmary map showing the thickness of glacial deposits in Ohio: U.S. Geological Survey Miscellaneous Field Studies Map 1862, scale 1:500,000.

Stout, Wilber, Lamborn, R.E., and Schaaf, Downs, 1932, Brines of Ohio: Ohio Division of Geological Survey Bulletin 37, $123 \mathrm{p}$.

*Strobel, M.L., 1993, Hydraulic properties of three types of glacial deposits in Ohio: U.S. Geological Survey Water-Resources Investigation Report 92-4135, $41 \mathrm{p}$.
*Strobel, M.L. and Bugliosi, E.F., 1991, Areal extent, hydrogeologic characteristics, and possible origins of the carbonate rock Newburg zone (Middle-Upper Silurian) in Ohio: Ohio Journal of Science, v. 91, no. 5, p. 209-215.

Strobel, M.L., and Faure, Gunter, 1987, Transport of indicator clasts by ice sheets and the transport half-distance-a contribution to prospecting for ore deposits: Journal of Geology, v. 95, p. 687697.

Sun, R.J., ed., 1986, Regional aquifer-system analysis program of the U.S. Geological Survey-Summary of projects, 1978-84: U.S Geological Survey Circular 1002, 264 p.

Toth, Jozsef, 1963, A theoretical analysis of groundwater flow in small drainage basins: Journal of Geophysical Research, v. 68, no. 16, p. 4795-4812.

U.S. Environmental Protection Agency, 1984, National secondary drinking-water regulations: U.S. Environmental Protection Agency, EPA-570/9-76-000, Appendix A, 37 p.

VanWagner, Elmer, III, 1988, An integrated investigation of the Bowling Green Fault using multispectral reflectance, potential field, seismic, and well log data sets: Bowling Green, Ohio, Bowling Green State University, unpublished Master's thesis, $171 \mathrm{p}$.

Walton, W.C., and Scudder, G.D., 1960, Ground-water resources of the valley-train deposits in the Fairborn area, Ohio: Ohio Department of Natural Resources, Division of Water Technical Report 3, $57 \mathrm{p}$.

Watkins, F.A., Jr., and Rosenshein, J.S., 1963, Ground-water geology and hydrology of Bunker Hill Air Force Base and vicinity, Peru, Indiana: U.S. Geological Survey Water-Supply Paper 1619-B, $32 \mathrm{p}$.

Whillans, Ian, 1985, Glacial geology of Central Ohio: Columbus, Ohio, the Ohio State University Institute of Polar Studies, (Guidebook for field Excursion 3, Sixth Gondwana symposium), Miscellaneous publication 226, $12 \mathrm{p}$.

Willman, H.B., Frye, J.C., Simon, J.A., Clegg, K.E., Swann, D.H., Atherton, Elwood, Collinson, Charles, Lineback J.A., and Buschbach, T.C., 1967, Geologic map of Illinois: Illinois State Geological Survey, scale 1:500,000, 1 sheet.

Young, H.L., 1992, summary of ground-water hydrology of the Cambrian-Ordovician aquifer system in the northern midwest: U.S. Geological Survey Professional Paper 1405-B, 99 p. 




\section{Selected Series of U.S. Geological Survey Publications}

\section{Books and Other Publications}

Professional Papers report scientific data and interpretations of lasting scientific interest that cover all facets of USGS investigations and research.

Bulletins contain significant data and interpretations that are of lasting scientific interest but are generally more limited in scope or geographic coverage than Professional Papers.

Water-Supply Papers are comprehensive reports that present significant interpretive results of hydrologic investigations of wide interest to professional geologists, hydrologists, and engineers. The series covers investigations in all phases of hydrology, including hydrogeology, availability of water, quality of water, and use of water.

Circulars are reports of programmatic or scientific information of an ephemeral nature; many present important scientific information of wide popular interest. Circulars are distributed at no cost to the public.

Fact Sheets communicate a wide variety of timely information on USGS programs, projects, and research. They commonly address issues of public interest. Fact Sheets generally are two or four pages long and are distributed at no cost to the public.

Reports in the Digital Data Series (DDS) distribute large amounts of data through digital media, including compact discread-only memory (CD-ROM). They are high-quality, interpretive publications designed as self-contained packages for viewing and interpreting data and typically contain data sets, software to view the data, and explanatory text.

Water-Resources Investigations Reports are papers of an interpretive nature made available to the public outside the formal USGS publications series. Copies are produced on request (unlike formal USGS publications) and are also available for public inspection at depositories indicated in USGS catalogs.

Open-File Reports can consist of basic data, preliminary reports, and a wide range of scientific documents on USGS investigations. Open-File Reports are designed for fast release and are available for public consultation at depositories.

\section{Maps}

Geologic Quadrangle Maps (GQ's) are multicolor geologic maps on topographic bases in 7.5- or 15-minute quadrangle formats (scales mainly 1:24,000 or 1:62,500) showing bedrock, surficial, or engineering geology. Maps generally include brief texts; some maps include structure and columnar sections only.

Geophysical Investigations Maps (GP's) are on topographic or planimetric bases at various scales. They show results of geophysical investigations using gravity, magnetic, seismic, or radioactivity surveys, which provide data on subsurface structures that are of economic or geologic significance.
Miscellaneous Investigations Series Maps or Geologic Investigations Series (I's) are on planimetric or topographic bases at various scales; they present a wide variety of format and subject matter. The series also incudes 7.5-minute quadrangle photogeologic maps on planimetric bases and planetary maps.

\section{Information Periodicals}

Metal Industry Indicators (MII's) is a free monthly newsletter that analyzes and forecasts the economic health of five metal industries with composite leading and coincident indexes: primary metals, steel, copper, primary and secondary aluminum, and aluminum mill products.

Mineral Industry Surveys (MIS's) are free periodic statistical and economic reports designed to provide timely statistical data on production, distribution, stocks, and consumption of significant mineral commodities. The surveys are issued monthly, quarterly, annually, or at other regular intervals, depending on the need for current data. The MIS's are published by commodity as well as by State. A series of international MIS's is also available.

Published on an annual basis, Mineral Commodity Summaries is the earliest Government publication to furnish estimates covering nonfuel mineral industry data. Data sheets contain information on the domestic industry structure, Government programs, tariffs, and 5-year salient statistics for more than 90 individual minerals and materials.

The Minerals Yearbook discusses the performance of the worldwide minerals and materials industry during a calendar year, and it provides background information to assist in interpreting that performance. The Minerals Yearbook consists of three volumes. Volume I, Metals and Minerals, contains chapters about virtually all metallic and industrial mineral commodities important to the U.S. economy. Volume II, Area Reports: Domestic, contains a chapter on the minerals industry of each of the 50 States and Puerto Rico and the Administered Islands. Volume III, Area Reports: International, is published as four separate reports. These reports collectively contain the latest available mineral data on more than 190 foreign countries and discuss the importance of minerals to the economies of these nations and the United States.

\section{Permanent Catalogs}

"Publications of the U.S. Geological Survey, 1879-1961" and "Publications of the U.S. Geological Survey, 19621970" are available in paperback book form and as a set of microfiche.

"Publications of the U.S. Geological Survey, 1971-1981" is available in paperback book form (two volumes, publications listing and index) and as a set of microfiche.

Annual supplements for 1982, 1983, 1984, 1985, 1986, and subsequent years are available in paperback book form. 


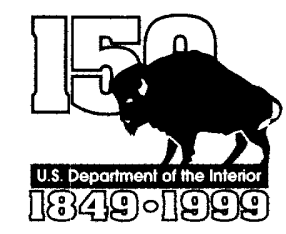

$x$

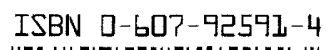

